UNIVERSIDADE DE SÃO PAULO

PROGRAMA DE PÓS GRADUAÇÃo EM ENERGIA

Jonathas Luiz de Oliveira Bernal

Modelagem para o Aproveitamento Sustentável dos Biocombustíveis, Energia Eólica e Solar dentro do PIR Local: Estudo de Caso do PIR da Região de Araçatuba 
Jonathas Luiz de Oliveira Bernal

\title{
Modelagem para o Aproveitamento Sustentável dos Biocombustíveis, Energia Eólica e Solar dentro do PIR Local: Estudo de Caso do PIR da Região de Araçatuba
}

\begin{abstract}
Dissertação apresentada ao Programa Interunidades de Pós-graduação em Energia da Universidade de São Paulo (Instituto de Eletrotécnica e Energia / Escola Politécnica / Instituto de Física / Faculdade de Economia e Administração) para obtenção do título de Mestre em Energia
\end{abstract}

Orientador: Prof. Dr. Miguel Edgar Morales Udaeta

São Paulo 


\section{AUTORIZO A REPRODUÇÃO E DIVULGAÇÃO TOTAL OU PARCIAL DESTE TRABALHO, POR QUALQUER MEIO CONVENCIONAL OU ELETRÔNICO, PARA FINS DE ESTUDO E PESQUISA, DESDE QUE CITADA A FONTE.}

FICHA CATALOGRÁFICA

Bernal, Jonathas Luiz de Oliveira.

Modelagem para o aproveitamento sustentável dos biocombustíveis, energia eólica e solar dentro do PIR local: estudo de caso do PIR da região de Araçatuba / Jonathas Luiz de Oliveira Bernal; orientador Miguel Edgar Morales Udaeta São Paulo, 2009.

138 p.: il.; $30 \mathrm{~cm}$.

Dissertação (Mestrado - Programa Pós-Graduação em Energia) EP / FEA / IEE / IF da Universidade de São Paulo.

1. Energia eólica 2. Energia solar 3. Biocombustíveis 4. Planejamento Integrado de Recursos I. Título. 


\section{UNIVERSIDADE DE SÃO PAULO \\ PROGRAMA DE PÓS-GRADUAÇÃO EM ENERGIA \\ EP - FEA - IEE - IF}

\section{JONATHAS LUIZ DE OLIVEIRA BERNAL}

"Modelagem para o aproveitamento sustentável dos biocombustíveis, energia eólica e solar dentro do PIR local: Estudo de caso do PIR da Região de Araçatuba"

Dissertação defendida e aprovada em 21/08/2009 pela Comissão Julgadora:

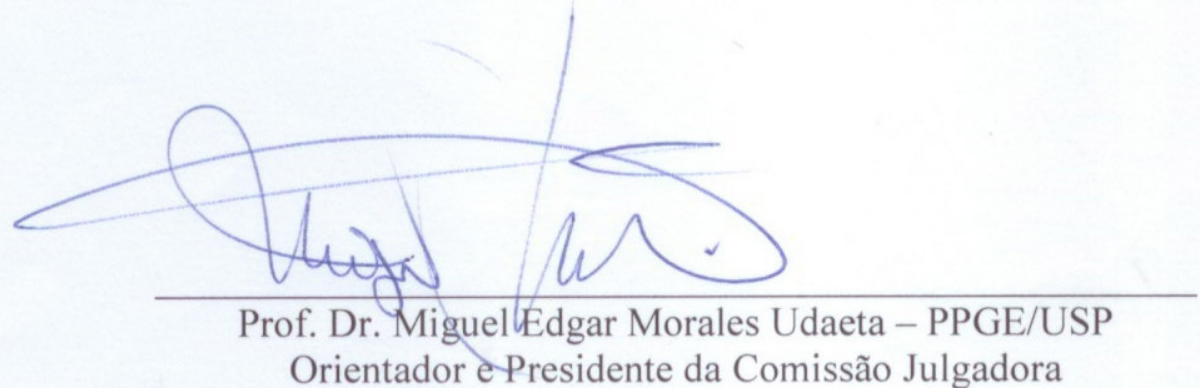

Orientador e Presidente da Comissão Julgadora

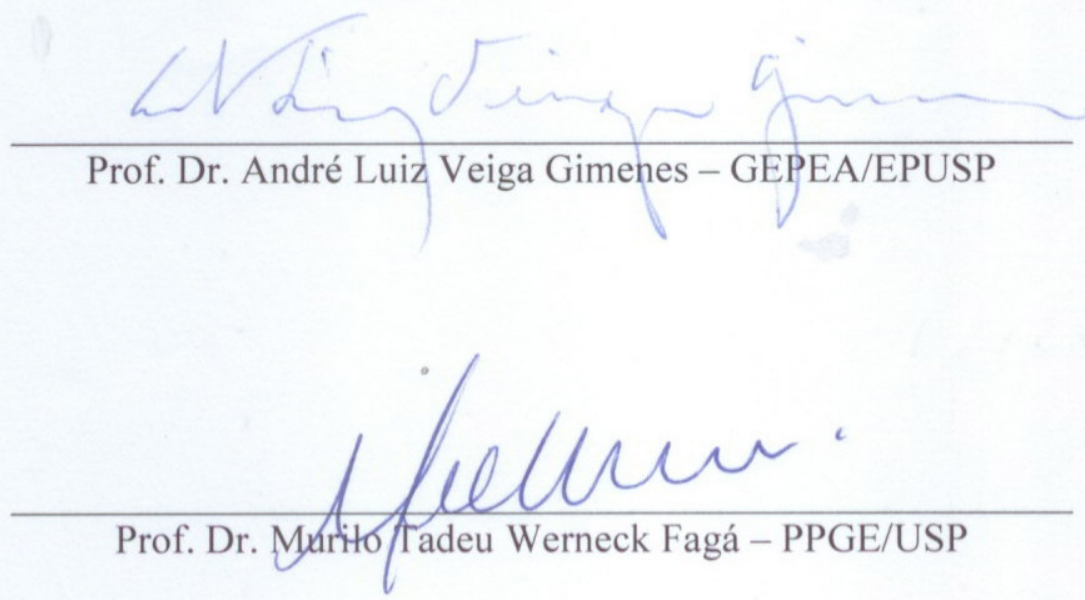




\section{DEDICATÓRIA}

A Francisco Bernal que me ensinou o que era a engenharia Aos meus pais, Luiz e Wanda Aos meus irmãos Lavínia e Ulysses 


\section{AGRADECIMENTOS}

Agradeço ao Prof. Dr. Miguel Edgar Morales Udaeta pela orientação não só científica e acadêmica, mas filosófica e profissional, que me faz acreditar ser hoje uma pessoa e um cidadão melhor do que quando o conheci.

Ao Prof. Dr. José Aquiles Baesso Grimoni, tanto na figura de diretor do Instituto de Eletrotécnica e Energia da Universidade de São Paulo, quanto na figura de professor, pesquisador e colaborador do desenvolvimento da metodologia PIR.

Ao Pascoal Henrique da Costa Rigolin, amigo de inestimável valor e que me trouxe à luz da pesquisa e todas as pessoas nela envolvidas, além da sua colaboração.

Aos integrantes do PIR na USP, em especial a Ricardo Baitelo, Paulo Kanayama, Paulo Carneiro, Mário Biague, Alexandre Reinig, Décio Cicone, André Gimenes, Felipe Coelho, Renata Freitas, Victor Katayama, Thiago Hiroshi, Isabel Sado, Julia Bellacosa Marina Martins e Thalita Marassato.

À minha família e à minha noiva, pela companhia nas horas difíceis, pela compreensão das horas de trabalho duro e compartilhamento das horas de alegria, em qualquer momento da minha vida.

Às amizades solidificadas ao longo desta caminhada.

Ao apoio financeiro da Agência Nacional do Petróleo, Gás Natural e Biocombustíveis - da Financiadora de Estudos e Projetos - FINEP - e do Ministério da Ciência e Tecnologia - MCT por meio do Programa de Recursos Humanso da ANP para o Setor Petróleo e Gás - PRH-ANP/MCT através da bolsa de estudos concedida e pelos 
recursos que possibilitaram o desenvolvimento do trabalho, e seu coordenador, Prof. Murilo Tadeu Werneck Fagá, grande amigo e exemplo.

À Fundação de Amparo à Pesquisa do Estado de São Paulo pelo fomento à pesquisa no projeto "Novos Instrumentos de Planejamento Energético Regional Visando o Desenvolvimento Sustentável", processo sob o $n^{\text {o }}$ 2003/06441-7 que possibilitou o desenvolvimento pleno do trabalho. 


\section{EPÍGRAFE}

"Porque as pequenas construções podem ser terminadas por seus arquitetos iniciais; as grandes, as verdadeiras, sempre deixam a pedra final para a posteridade." - Herman Melville 


\section{RESUMO}

O objetivo do trabalho é avaliar os recursos energéticos eólico, solar e biocombustíveis disponíveis na Região Administrativa de Araçatuba, através da metodologia de Planejamento Integrado de Recursos Energéticos, que busca sistematizar e qualificar os impactos inerentes à utilização energética integrando a oferta e a demanda e buscando o menor custo completo considerando as características de cada recurso energético nas dimensões ambiental, social, política e técnico-econômica. Trabalhando com a Previsão de Demanda para os cenários energéticos Tendencial, Sustentável, Otimista e SustentávelPrimoroso para a integração dos Recursos energéticos ao longo do Tempo e considerando os Vigilantes do Mapeamento Energoambiental, buscando o atendimento de demanda local e de exportação de energia. Permitindo assim concluir que os recursos energéticos considerados poderão atender os requerimentos da demanda em todos os cenários, porém com a possibilidade de esgotamento em determinados cenários com horizonte de planejamento maiores que 30 anos.

Palavras Chave: Planejamento Integrado de Recursos, Energia Eólica, Biocombustíveis, Energia Solar. 


\begin{abstract}
The aims of this work is to evaluate the wind power, solar energy resources and biofuels available in Araçatuba through integrated resources planning methodology, which seeks to systemize and qualify the impacts associated with the use of energy by integrating supply and demand and seeking the lowest full-cost recital characteristics of each energy resource in environmental, social, political and technical-economic dimensions. Working with the demand forecast for trend, sustainable energy scenarios, optimistic and sustainable-prime as a PIN for the integration of energy resources over time, and considering the vigilant of Energy-environmental parameters, fetching mapping meeting local demand and export of energy. Thus conclude that the energy resources considered may meet the requirements of demand in all scenarios, but with the possibility of exhaustion in certain scenarios with planning horizon larger than 30 years.
\end{abstract}

Key words: Integrated Resources Planning, Wind Energy, Solar Energy, Biofuels. 


\section{LISTA DE ABREVIATURAS}

PIR - Planejamento Integrado de Recursos Energéticos

RAA - Região Administrativa de Araçatuba

RELO - Recurso Energético do Lado da Oferta

RELD - Recurso Energético do Lado da Demanda

CVPC - Cômputo e Valoração do Potencial Completo

En-In - Envolvidos e Interassados

$\Sigma \mathrm{RE}$ - Integração dos Recursos Energéticos

ACC - Avaliação de Custos Completos

PAH - Processo de Análise Hierárquica

FC - Fator de Capacidade

DBO - Demanda Biológica de Oxigênio

DQO - Demanda Química de Oxigênio

MP - Material Particulado

O\&M - Operação e Manutenção

ANP - Agência Nacional do Petróleo, Gás Natural e Biocombustíveis 


\section{LISTA DE FIGURAS}

Ilustração 1: Diagrama Esquemático do Planejamento Integrado de Recursos energéticos 4

Ilustração 2: Gráfico de frequência das velocidades do vento percentualmente em escala de $1 \mathrm{~m} / \mathrm{s}$ para a RAA 8

Ilustração 3: Gráfico da Equação 2-5 para a RAA 11

Ilustração 4: perfil de velocidade do vento de acordo com a altura do solo 14

Ilustração 5: distribuição de usos do solo na RAA 16

Ilustração 6: Gráfico da média de energia incidente $\left(\mathrm{kW} / \mathrm{m}^{2}\right)$ 31

Ilustração 7: distribuição do consumo de energia 66

Ilustração 8: Distribuição de Residências eletrificadas (a) e de Residências Urbanas e Rurais (b) 67

Ilustração 9: Distribuição de Classes entre residências 68

Ilustração 10: distribuição da população urbana/rural 73

Ilustração 11: Dirstribuição de residências urbanas por classe 74

Ilustração 12: Alteração da distribuição de classes de renda ao longo do tempo 74

Ilustração 13: Participação das tecnologias de Iluminação ao longo do tempo, Classes $C$, B e A 76

Ilustração 14: número de estabelecimentos/residências e crescimento setorial 78

Ilustração 15: Distribuição de Renda ao longo do tempo, por classes de rendimento. 80

Ilustração 16: demanda de energia elétrica 94

Ilustração 17 a e b: Consumo de energia elétrica por classes - Setor residencial 95

Ilustração 18: Consumo de energia por setor 96 


\section{LISTA DE TABELAS}

Tabela 1: Frequência de velocidade do vento aferida na RAA 8

Tabela 2: Parâmetros X e Y de linearização na RAA 11

Tabela 3: Velocidade média anual e variância para a RAA 12

Tabela 4: Especificações técnicas de operação dos Anemômetros 13

Tabela 5 Índice de descrição do terreno 15

Tabela 6: distribuição em área do uso do solo na RAA 16

Tabela 7: Projeção das velocidades dos ventos para 50m e 100m de altura na RAA 17

Tabela 8: Potencial Eólico por $\mathrm{m}^{2}$ de varredura de pás a $50 \mathrm{~m}$ 18

Tabela 9: Potencial Eólico por $m^{2}$ de varredura de pás a $100 m$ 19

Tabela 10: potência e energia por turbina de 1500kW e fator de capacidade 20

Tabela 11: média de energia por metro quadrado incidente de radiação solar 32

Tabela 12: Distribuição da população em Residências e Classes Econômicas 63

Tabela 13: Distribuição de Eletrodomésticos por Classe de Renda 64

Tabela 14:Potência instalada em lâmpadas e média de uso em residências da Classe C 65

Tabela 15: Relativização de uso de energéticos para cocção - Brasil 66

Tabela 16: Previsão de consumo de energia no setor residencial (em mil MWh/ano) 93

Tabela 17: Previsão de Consumo de energia do setor residencial por energético (em mil MWh/ano) 93

Tabela 18: Previsão do consumo de energia por setor (mil MWh/ano) 93 
Tabela 19: Previsão de consumo de energia elétrica por setor (mil GWh)

Tabela 20: Previsão de consumo por setor: Cenário Sustentável (mil MWh) 95

Tabela 21: Consumo de energia elétrica por setor (mil GWh/ano) 96

Tabela 22: Consumo total de energia por setor 97

Tabela 23: Consumo de energia elétrica por setor (mil GWh/ano) 98

Tabela 24: Previsão de Consumo de energia elétrica para o cenário Otimista (mil GWh ano) 99

Tabela 25: expectativa de exportação de energia elétrica por cenário em GWh 100

Tabela 26: Rankinq dos recursos considerados 106

Tabela 27: Vigilantes do Mapeamento Energoambiental para a RAA 107

Tabela 28: Volume de energia e bloco mínimo por recurso 109

Tabela 29: Demanda requerida para o Cenário Tendencial (mil MWh) 110

Tabela 30: Atendimento à demanda do cenário Tendencial (GWh) 111

Tabela 31: Requerimentos da demanda do cenário Sustentável (mil MWh) 111

Tabela 32: Atendimento da demanda para o cenário Sustentável (mil MWh) 112

Tabela 33: requerimento de energia do Cenário Otimista com perdas (mil GWh) 112

Tabela 34: Previsão do atendimento da demanda com os recursos disponíveis (em mil MWh) 113

Tabela 35: Requerimentos da demanda para o cenário Sustentável-Primoroso 113

Tabela 36: Lre para atendimento da demanda no cenário sustentável-primoroso 114 


\section{SUMÁRIO}

$1 \quad$ Introdução

1.1 O Planejamento Integrado de Recursos Energéticos 1

1.2 Objetivos do Trabalho 5

1.2.1 Objetivos Gerais 5

1.2.2 Objetivos Específicos 5

2 Caracterização dos Recursos Energéticos 6

2.1 Energia Eólica 6

2.1.1 Função Velocidade do Vento 6

2.1.2 Vento Turbulento 12

2.1.3 Potencial Eólico 17

2.1.4 Tecnologia e Potencial de aproveitamento 19

2.1.5 Cômputo e Valoração do Potencial Completo Eólico 21

\subsection{Energia Solar} 30

2.2.1 Radiação Solar 30

2.2.2 Temperatura 32

2.2.3 Tecnologia de aproveitamento solar fotovoltaico 33

2.2.4 Coletores solares para aquecimento 34 
3.4.1 Ano Base para a Região Administrativa de Araçatuba 61

3.4.2 Índices de participação setorial e intensidades energéticas 62 
3.9.1 Previsão de Demanda para o Cenário Tendencial

3.9.2 Previsão de Demanda para o Cenário Sustentável

4.2 Incorporação de Ferramentas de Planejamento na Integração de Recursos 104

4.2.1 Ranqueamento de Recursos energéticos 104

4.2.2 Mapeamento Energoambiental 106

4.3 Aplicação da Integração dos Recursos para a RAA 108

4.3.1 Premissas de Atendimento à Demanda da RAA 108

$5 \quad$ Resultados e Conclusões 110

5.1 Resultados para o Cenário Tendencial 110

5.2 Resultados para o Cenário Sustentável 111

5.3 Resultados para o Cenário Otimista 112

5.4 Resultados para o Cenário Sustentável-Primoroso 113 
5.5.1 Acerca do Planejamento Energético 


\section{INTRODUÇÃo}

\subsection{O Planejamento Integrado de Recursos Energéticos}

O aproveitamento de recursos energéticos de um modo geral traz consigo características inerentes, tanto no que se refere à fonte energética quanto à tecnologia de aproveitamento, de impactos socioambientais. Sejam estes impactos grandes ou pequenos, positivos ou negativos, eles sempre estarão presentes.

O objetivo do planejamento energético, e mais especificamente do PIR, é sistematizar estes recursos energéticos, as necessidades para sua utilização, potenciais, impactos e características gerais para que tais impactos possam ser menores, ao longo do tempo, do que a simples provisão da necessidade imediata por energia.

O PIR nasceu da necessidade de se integrar, já na etapa de planejamento, a oferta e a demanda por energia de forma a considerar não só recursos energéticos do lado da oferta para atendimento de uma previsão de demanda, como é realizado pelo planejamento energético tradicional, em que a previsão de demanda se confunde com a sua projeção, mas também recursos energéticos do lado da demanda são inclusos para o atendimento desta previsão.

O PIR aqui trabalhado além de apenas integrar oferta e demanda, também incorpora diversos outros elementos metodológicos de análise. Incluindo a caracterização a priori dos RELOs e dos RELDs quanto às dimensões social, ambiental e política, além das características técnico-econômicas usuais no planejamento tradicional.

A metodologia de PIR visa o auxílio à tomada de decisão em busca do melhor aproveitamento dos recursos energéticos de uma determinada região de forma a sistematizar 
as informações sobre geografia, meio ambiente, disponibilidade de fontes energéticas e infraestrutura em busca do desenvolvimento sustentável.

O desenvolvimento sustentável será aqui descrito como o bem estar geral a partir das necessidades básicas atendidas e dentro das possibilidades reais da sociedade, com o mínimo de produtos secundários e máxima eficiência de processos e minimização de impactos socioambientais. Isso tudo com o atendimento à demanda local. Como se constata a partir das idéias de Aristóteles:

... tanto o vulgo como os homens de cultura superior dizem que esse bem supremo é a felicidade e consideram que o bem viver e o bem agir equivalem a ser feliz; porém divergem a respeito do que seja a felicidade, e o vulgo não sustenta a mesma opinião dos sábios. A maioria das pessoas pensa que se trata de alguma coisa simples e óbvia como o prazer, a riqueza... embora discordem entre si...Ora, há quem pense que, à parte desses numerosos bens, existe um outro que é bom por si mesmo e que também é a causa da bondade de todos os outros. Seria infrutífero examinar todas as opiniões que têm sido sustentadas a esse respeito; basta considerar as mais difundidas ou aquelas que parecem ser mais razoáveis.

"Desenvolvimento Sustentável é o conjunto de processos e atitudes que atendem às necessidades presentes sem comprometer a possibilidade de que as gerações futuras satisfaçam as suas próprias necessidades" (PNUMA, 1987).

De um modo geral, o PIR pode ser dividido em quatro grandes fases de aplicação da metodologia:

1. Informações prévias: para um exercício de aplicação do PIR, as informações contidas nesta fase devem ser pré-existentes, cabendo apenas sua organização sistemática para utilização dentro do PIR. Fazem parte das informações prévias o Inventário 
Energoambiental da região de aplicação, a listagem dos recursos energéticos disponíveis e a identificação dos En- $\operatorname{In}^{1}$.

2. Caracterização dos Recursos Energéticos: Conhecida a região de aplicação da metodologia PIR, é necessário que se conheçam detalhadamente os recursos energéticos passíveis de aproveitamento, sendo separados por fontes energéticas e caracterizados por tecnologias. Após uma seleção prévia, tanto RELOs quanto RELDs são caracterizados sob todos os atributos pertinentes aos aspectos social, ambiental, política e técnico-econômica, dando valores a esses aspectos. E, por fim, é levantado o potencial teórico dos recursos energéticos.

3. Previsão de Demanda: o consumo energético se calca no uso final a que se dá para a energia e a tecnologia para que o serviço energético seja aproveitado. A composição de diferentes cenários energéticos e socioeconômicos pode transformar a visão futura de usos finais, serviços energéticos ou tecnologias e modificar, aumentando ou diminuindo, o acesso a esses usos finais. A partir destes cenários compostos é possível prever a demanda energética em cada um deles.

4. Integração de Recursos Energéticos: O atendimento da demanda prevista pelos diferentes cenários através dos recursos energéticos listados e caracterizados deve obedecer ao ranqueamento destes recursos, através da ACC, a fim de serem considerados ao longo do horizonte de planejamento em que o exercício de PIR está inserido. Dentro dessa inserção

\footnotetext{
${ }^{1}$ A Idéia de En-In remete ao termo inglês stakeholders, porém, na aplicação do PIR, muito mais que
} apenas os stakeholders, a participação se amplia para organizações não governamentais, poder público, Especialistas nas diferentes áreas do conhecimento abrangidas no Planejamento Energético que considera aspectos ambientais, sociais e políticos a priori, enfim, a sociedade organizada como um todo. 
deve se considerar o mapeamento energoambiental, retrato da região no momento em que se analisa a entrada do enésimo recurso e o efeito deste recurso neste mapeamento.

A Ilustração 1 a seguir apresenta as etapas organizadas que compôem a metodologia do PIR:

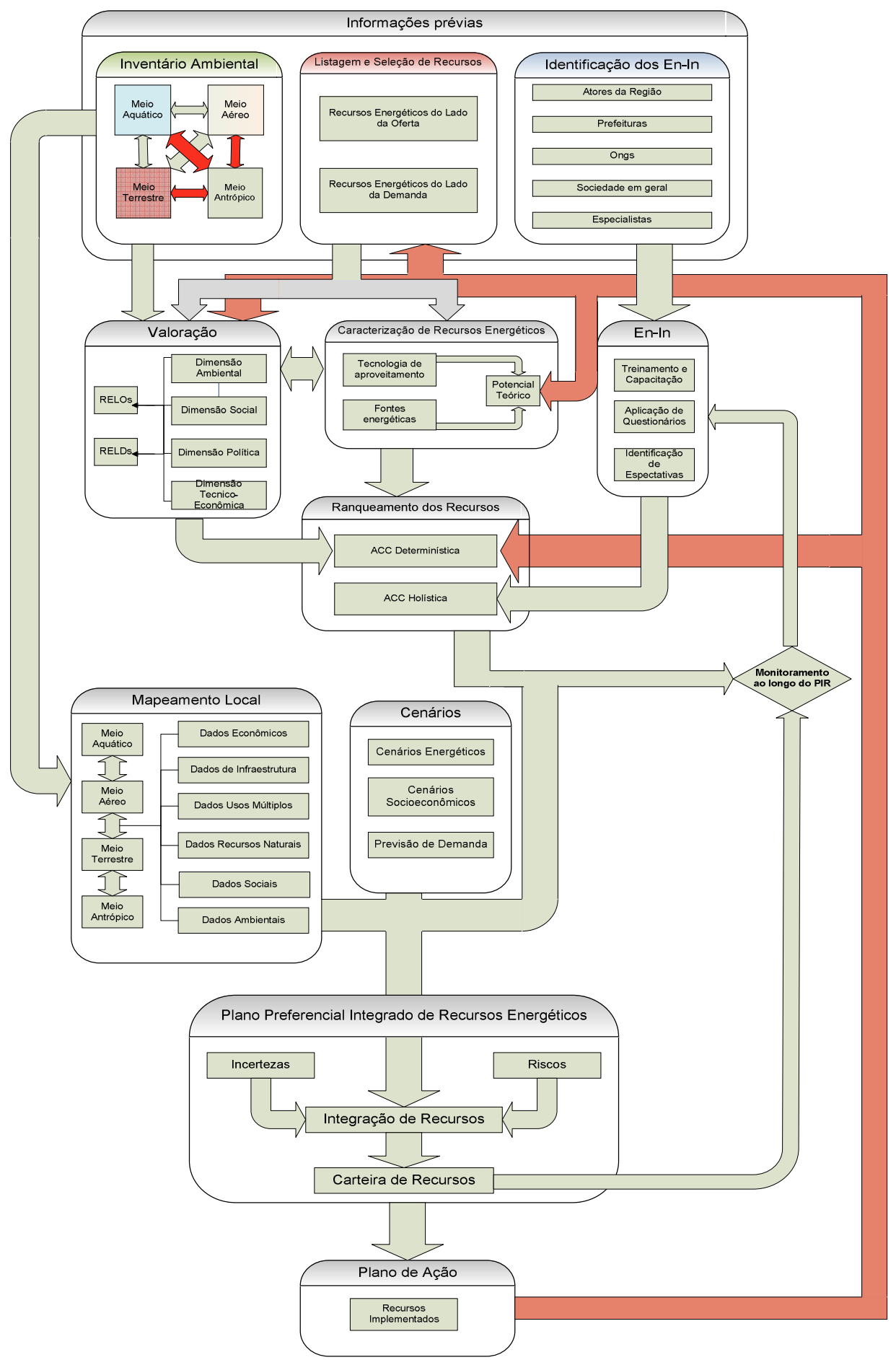

Ilustração 1: Diagrama Esquemático do Planejamento Integrado de Recursos energéticos 


\subsection{Objetivos do Trabalho}

\subsubsection{Objetivos Gerais}

Avaliar os RELOs eólico, solar e biocombustíveis disponíveis na RAA, introduzindoos na metodologia de Planejamento Integrado de Recursos Energéticos, qualificando-os com a previsão de demanda e perspectivas regionais através de critérios sociais, ambientais, políticos e técnico-econômicos, garantindo a disponibilidade de recursos para atender a demanda de exportação de energia característica local, alocando os recursos geográfica e temporalmente.

\subsubsection{Objetivos Específicos}

- Estudar a utilização de fontes renováveis de energia dentro do PIR Local;

- Levantamento dos potenciais de aproveitamento dos recursos energéticos eólico, solar e de biocombustíveis, caracterizando suas possibilidades de aproveitamento na região;

- Valorar os Recursos Energéticos em questão dentro das dimensões de análise do Planejamento Integrado de Recursos (Técnico-Econômica, Ambiental, Social e Política);

- Construir Cenários que possibilitem o vislumbre das perspectivas de Demanda energética e a necessidade de Recursos Energéticos de Oferta para suprir tais requerimentos;

- Inserir os Recursos energéticos em estudo dentro do Planejamento Integrado de Recursos da RAA 


\section{CaracterizaÇão dos Recursos EnERgéticos}

Os RELOs se caracterizam pelo duo fonte energética e tecnologia de aproveitamento (Fujii, 2006). Sendo que caracterização completa dos recursos passa por levantar e descrever o potencial energético da fonte, assinalar as tecnologias de aproveitamento passíveis de uso, sendo possível se considerar tecnologias que possam atingir a maturidade ao longo do horizonte de planejamento, valorar os RELOs nas dimensões de análise do PIR e com isso obter o seu potencial realizável.

Neste trabalho serão caracterizadas as fontes energéticas eólica, solar e biocombustíveis, sendo esta última dividida entre biodiesel e etanol de cana-de-açúcar.

\subsection{Energia Eólica}

O levantamento do potencial de energia eólica de uma região é dependente de uma série de fatores meteorológicos e geográficos que devem estar adequadamente mapeados e organizados sistematicamente.

Os ventos surgem devido a diferenças de pressão ao longo da superfície terrestre que são causadas por diferenças na quantidade de radiação solar recebida pela região do equador e pelos pólos, além do efeito da força de coriolis.

\subsubsection{Função Velocidade do Vento}

A velocidade do vento, em uma representação espectral, se divide em três componentes:

Zona de baixas freqüências, que corresponde a movimentos de grandes massas de ar e representam a maior parte da energia eólica aproveitável. 
Zona de altas freqüências, que corresponde a poucos segundos e está relacionada com a turbulência atmosférica.

Zona vazia, com muito pouca energia associada.

Essa estrutura permite que se utilize, para fins energéticos, a função de velocidade na forma:

$$
v(t)=\bar{v}+v^{\prime}(t)
$$

Equação 2-1: função velocidade do vento para energia

Onde:

$\bar{v}$ é a velocidade média anual, referente à zona de baixas freqüências. É chamado de regime quase estacionário pois as variações são muito mais lentas que as variações de turbulência.

$v^{\prime}(t)$ é a turbulência associada à estrutura do vento.

A consideração apenas da velocidade média anual do vento mascara todas as variações, lentas ou rápidas, podendo afetar seriamente o levantamento do potencial eólico da região (Castro, 2007).

Para amenizar este efeito, é necessário que se distribua as aferições em densidades de probabilidades, sendo expresso em percentual de freqüência de ocorrência de cada velocidade como apresentado na Ilustração 2 e na Tabela 1 representativa das velocidades aferidas na RAA em uma altura padrão de 30m através de um sistema meteorológico utilizado para medições de velocidade e direção do vento a $10 \mathrm{~m}$ e $30 \mathrm{~m}$, pluviosidade, temperatura, pressão, umidade e radiação solar. Este sistema meteorológico se encontra na cidade de Araçatuba, e está vinculado ao projeto FAPESP nº 03/06441-7. 


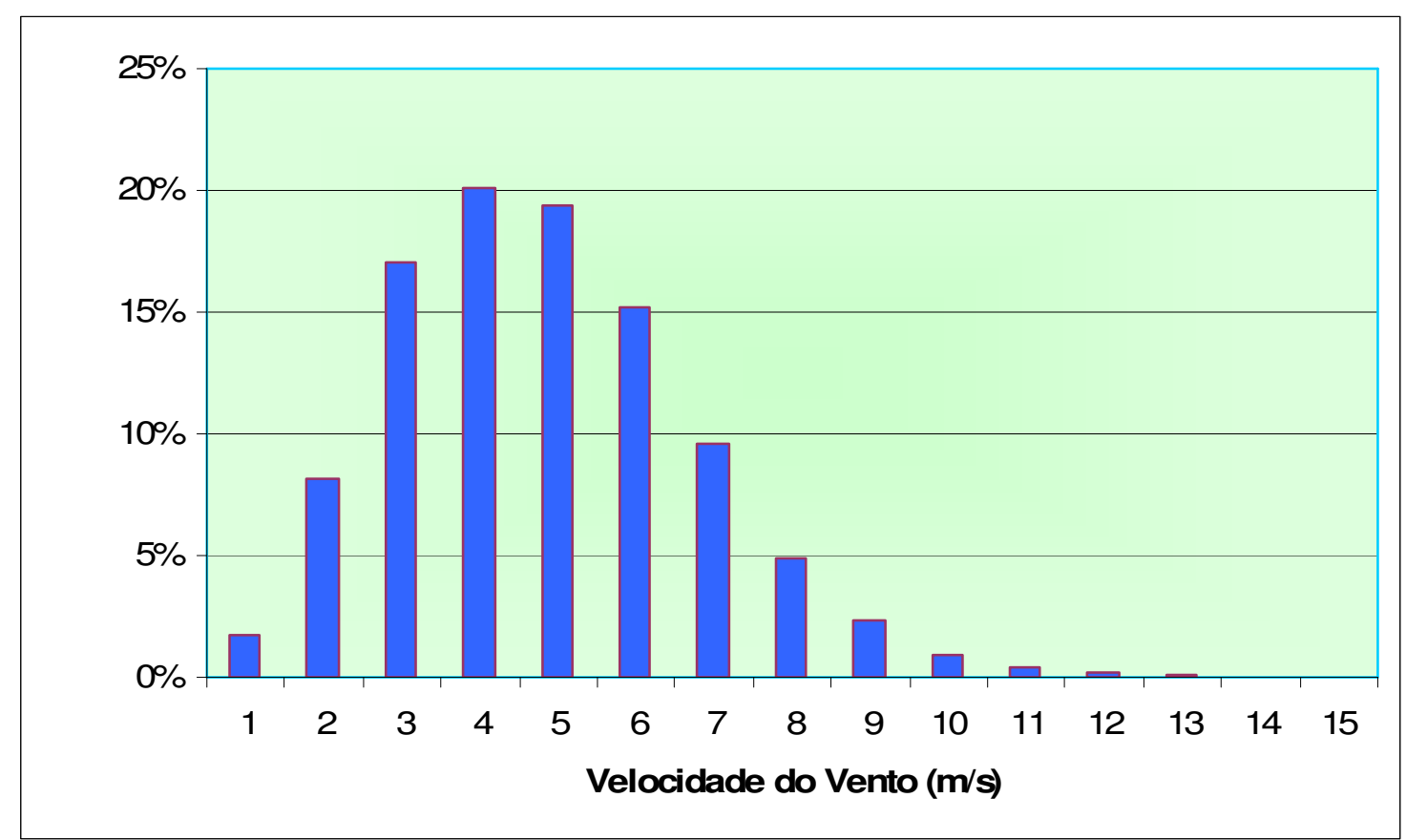

Ilustração 2: Gráfico de frequência das velocidades do vento percentualmente em escala de $1 \mathrm{~m} / \mathrm{s}$ para a RAA

Fonte: Elaboração Própria

Tabela 1: Frequência de velocidade do vento aferida na RAA

\begin{tabular}{|c|c|c|c|}
\hline velocidade $(\mathrm{m} / \mathrm{s})$ & Frequência (horas) & $\%$ frequência & Probabilidade acumulada \\
\hline 1 & 155 & $2 \%$ & $99,115 \%$ \\
\hline 2 & 715 & $8 \%$ & $94,150 \%$ \\
\hline 3 & 1493 & $17 \%$ & $81,549 \%$ \\
\hline 4 & 1764 & $20 \%$ & $62,960 \%$ \\
\hline 5 & 1696 & $19 \%$ & $43,213 \%$ \\
\hline 6 & 1328 & $15 \%$ & $25,956 \%$ \\
\hline 7 & 840 & $10 \%$ & $13,584 \%$ \\
\hline 8 & 429 & $5 \%$ & $6,342 \%$ \\
\hline 9 & 202 & $2 \%$ & $2,739 \%$ \\
\hline 10 & 82 & $1 \%$ & $1,118 \%$ \\
\hline 11 & 33 & $0 \%$ & $0,459 \%$ \\
\hline 12 & 17 & $0 \%$ & $0,169 \%$ \\
\hline 13 & 6 & $0 \%$ & $0,037 \%$ \\
\hline 14 & 0 & $0 \%$ & $0,002 \%$ \\
\hline 15 & 0 & $0 \%$ & $0,000 \%$ \\
\hline
\end{tabular}

Fonte: Elaboração própria 
A função densidade de probabilidade pode ser representada analiticamente pela distribuição de Weibull, que traz consigo informações úteis para o levantamento da velocidade média e variância. Sendo a função de densidade de probabilidade de Weibull:

$$
f(\bar{v})=\frac{k}{c}\left(\frac{\bar{v}}{c}\right)^{k-1} \exp \left[-\left(\frac{\bar{v}}{c}\right)^{k}\right]
$$

Equação 2-2: distribuição de Weibull

Onde:

c é parâmetro de escala em velocidade $(\mathrm{m} / \mathrm{s})$

k é parâmetro de forma adimensional

$\bar{v}$ é a velocidade média do vento $(\mathrm{m} / \mathrm{s})$

Para a obtenção dos parâmetros k e c é necessária uma regressão linear da distribuição de Weibull, sendo isso possível a partir da função de probabilidade acumulada da distribuição, dada por:

$$
F(v)=1-\int_{-\infty}^{v_{0}} f(v) d v
$$

Equação 2-3: Probabilidade acumulada da distribuição da velocidade

Que leva à:

$$
F(\bar{v})=\exp \left[-\left(\frac{\bar{v}}{c}\right)^{k}\right]
$$

Equação 2-4: Probabilidade acumulada para distribuição de Weibull

A Tabela 1 apresenta as probabilidades acumuladas de ocorrência de ventos para as velocidades correspondentes na RAA 
Traduzindo a Equação 2-4 em uma função linear temos:

$$
\begin{aligned}
& y=A x+b \\
& \text { onde } \\
& y=\ln [-\ln [F(\bar{v})] \\
& e \\
& x=\ln (\bar{v})
\end{aligned}
$$

Equação 2-5: função linear de probabilidades acumuladas

Em que:

$$
\begin{aligned}
& k=A \\
& e \\
& c=\exp \left(-\frac{b}{A}\right)
\end{aligned}
$$

Equação 2-6:correlação dos parâmetros $k$ e c com os índices lineares b e A

Para a RAA, a partir da Tabela 1 obtem-se os valores de X e Y observados na Tabela 2 que permitem, através da Ilustração 3, a obtenção dos coeficientes A e b, e assim os parâmetros c e k para a distribuição de probabilidades para a RAA.

Notar que o gráfico não é exatamente linear devido ao intervalo em que se distribuem as velocidades do vento, discretizadas a cada $1 \mathrm{~m} / \mathrm{s}$, que distorcem a reta, porém necessária para o tratamento dos dados com maior facilidade. 
Tabela 2: Parâmetros X e Y de linearização na RAA

Fonte: Elaboração Própria

\begin{tabular}{|c|c|}
\hline$X$ & $Y$ \\
\hline 0,00 & $-4,72$ \\
\hline 0,69 & $-2,81$ \\
\hline 1,10 & $-1,59$ \\
\hline 1,39 & $-0,77$ \\
\hline 1,61 & $-0,18$ \\
\hline 1,79 & 0,30 \\
\hline 1,95 & 0,69 \\
\hline 2,08 & 1,01 \\
\hline 2,20 & 1,28 \\
\hline 2,30 & 1,50 \\
\hline 2,40 & 1,68 \\
\hline 2,48 & 1,85 \\
\hline 2,56 & 2,07 \\
\hline 2,64 & 2,38 \\
\hline
\end{tabular}

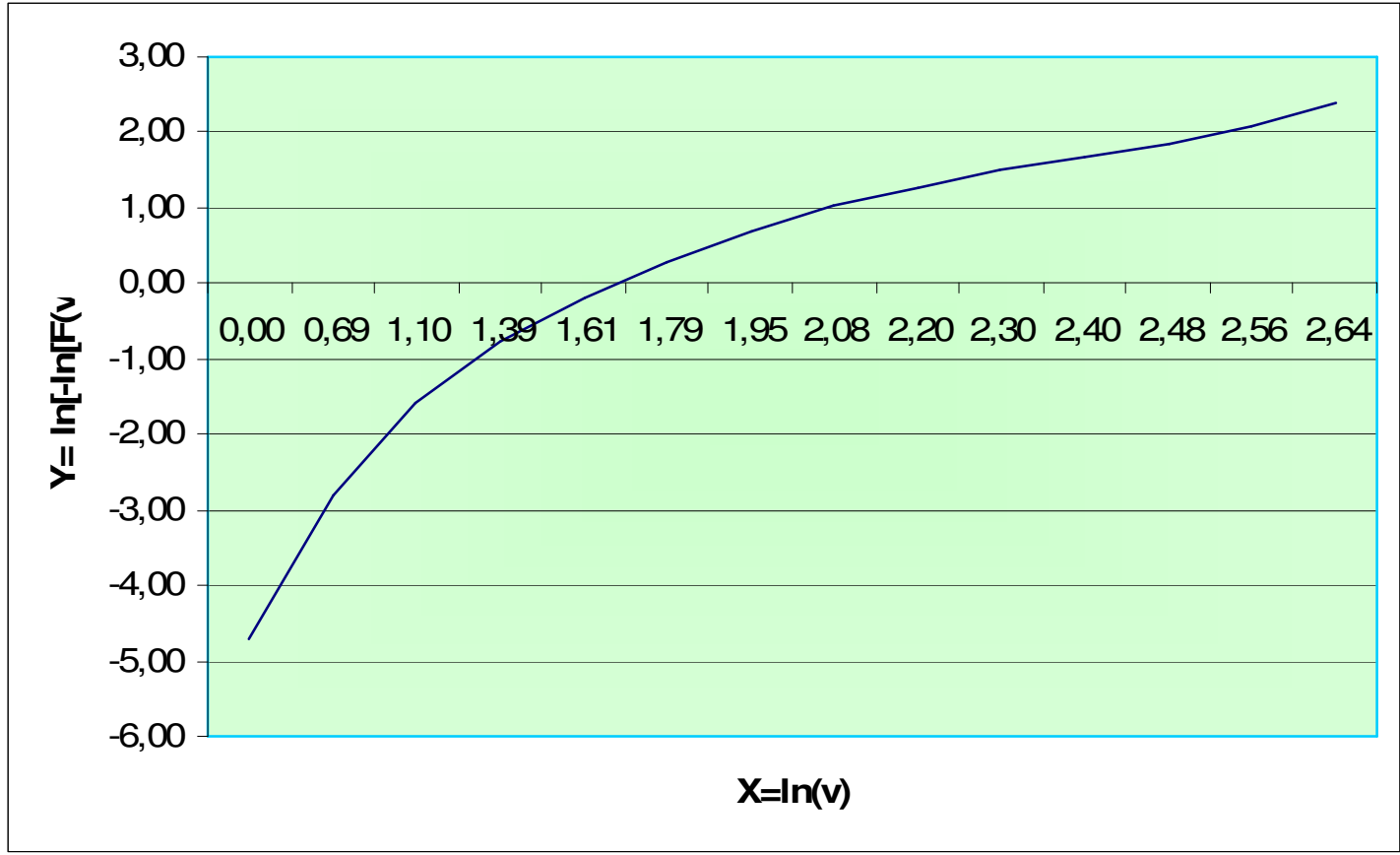

Ilustração 3: Gráfico da Equação 2-5 para a RAA

Fonte: Elaboração Própria

Do gráfico obtemos:

$$
\begin{aligned}
& b=-4,72 \\
& e \\
& A=2,82
\end{aligned}
$$


Donde também se obtém

$$
\begin{aligned}
& c=5,32(\mathrm{~m} / \mathrm{s}) \\
& e \\
& k=2,82
\end{aligned}
$$

A velocidade média anual e a sua variância podem ser obtidas pela relação de c e k na função $\Gamma$ :

$$
\Gamma(x)=\int_{0}^{\infty} e^{-u} u^{x-1} d u
$$

Equação 2-7: função gama

$$
\bar{v}_{a}=c \Gamma\left(1+\frac{1}{k}\right)
$$

Equação 2-8: Função de velocidade média anual

$$
\sigma^{2}=c^{2}\left[\Gamma\left(1+\frac{2}{k}\right)-\left(\Gamma\left(1+\frac{1}{k}\right)^{2}\right)\right]
$$

Equação 2-9: Variância da velocidade do vento

A apresenta a

Tabela 3: Velocidade média anual e variância para a RAA

Fonte: Elaboração Própria

\begin{tabular}{|c|c|}
\hline velocidade média anual & 4,74 \\
\hline variância & 3,31 \\
\hline
\end{tabular}

\subsubsection{Vento Turbulento}

O escoamento do ar pela superfície do terreno gera um atrito que altera a velocidade média do vento a medida em que se muda a referência de altura com relação ao solo até que se anule a aproximadamente 2000 metros de altitude. Como os aproveitamentos eólicos se 
encontram na faixa aproximada de apenas 100 metros do solo, essa interferência deve ser considerada quando da caracterização e levantamento do potencial.

A medição da velocidade e direção do vento na RAA é feita com anemômetros $M e t$ One Wind Set modelos 034B - L30 - NM e 034B - L90 - NM, sendo a diferença entre os modelos ocorre por conta da altura em que são instalados (30 e 90 pés). A Tabela 4 traz as especificações dos anemômetros utilizados:

Tabela 4: Especificações técnicas de operação dos Anemômetros

\begin{tabular}{|l|c|l|}
\hline Característica & Especificação & Unidade \\
\hline Limite mínimo de velocidade & 0 & $\mathrm{~m} / \mathrm{s}$ \\
\hline Limite máximo de velocidade & 49 & $\mathrm{~m} / \mathrm{s}$ \\
\hline Limiar de início de operação & 0,4 & $\mathrm{~m} / \mathrm{s}$ \\
\hline $\begin{array}{l}\text { Precisão para velocidades } \\
\text { inferiores a 10,1 m/s }\end{array}$ & 0,12 & $\mathrm{~m} / \mathrm{s}$ \\
\hline $\begin{array}{l}\text { Precisão para velocidades } \\
\text { superiores a 10,1 m/s }\end{array}$ & 1,1 & $\begin{array}{l}\text { \% da } \\
\text { velocidade } \\
\text { medida }\end{array}$ \\
\hline Intervalo de medição de ângulo & 0 a 360 & - \\
\hline Precisão & 4 & $\underline{0}$ \\
\hline Resolução & 0,5 & $\underline{0}$ \\
\hline Temperatura de Operação & -30 a 70 & -C \\
\hline
\end{tabular}

Fonte: Manual de operação Campbell Scientifics

A velocidade do vento tem um perfil exponencial desde o solo até alturas mais elevadas. Esse perfil exponencial permite que se extrapole uma velocidade obtida em uma determinada altura para outra em que se deseja obter a velocidade como é possível observar na Ilustração 4 e, conseqüentemente, o seu potencial energético. 


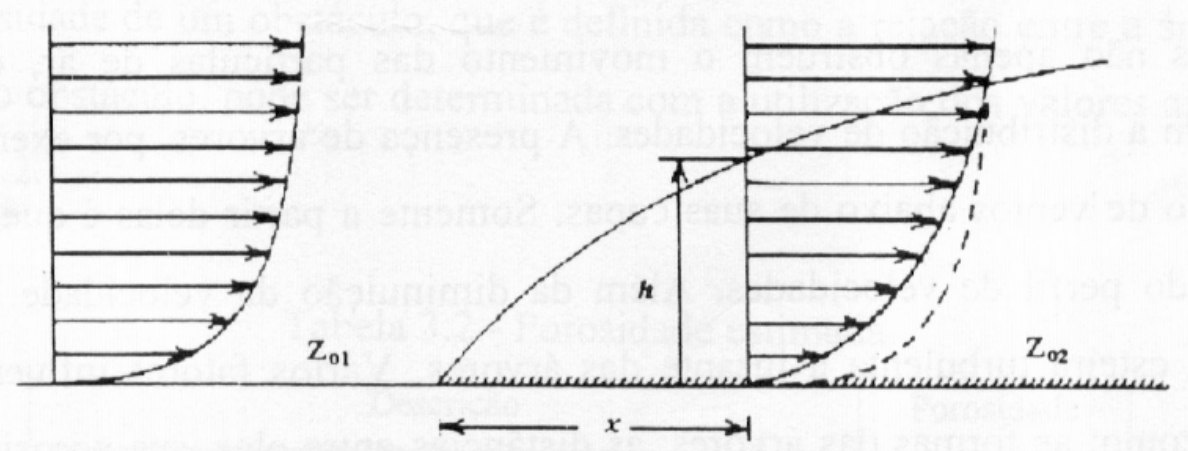

Ilustração 4: perfil de velocidade do vento de acordo com a altura do solo

Fonte: Pereira, 2007

A velocidade de uma determinada altura é então dada por:

$$
V=V_{0}\left(H / H_{0}\right)^{n}
$$

Equação 2-10: Transposição da velocidade do vento para diferentes alturas a partir do seu perfil

Onde

$V$ é a velocidade à altura em que se quer determinar o potencial

$V_{0}$ é a velocidade medida

$H$ é a altura a se determinar o potencial

$H_{0}$ é a altura em que foi feita a medida

$n$ é o índice de descrição do terreno, determinado na Tabela 5 
Tabela 5 Índice de descrição do terreno

\begin{tabular}{|c|c|}
\hline Descrição do Terreno & $\mathrm{n}$ \\
\hline Terreno sem Vegetação & 0,10 \\
\hline Terreno Gramado & 0,12 \\
\hline Terreno Cultivado & 0,19 \\
\hline Terreno com Poucas Árvores & 0,23 \\
\hline Terrenos com Muitas Árvores, cercas vivas ou poucas edificações & 0,26 \\
\hline Florestas & 0,28 \\
\hline
\end{tabular}

Fonte: Fadigas, 2007

O ideal de medição das condições de velocidade e direção do vento é se realizar em diversos pontos da zona considerada ao longo de vários anos para que se possa obter com precisão a média de velocidade dos ventos, índices de dispersão, e um mapeamento do potencial eólico em todo o espaço de estudo. Porém a urgente necessidade de obtenção dos potenciais para um rápido aproveitamento energético levou a construção de modelos para que se possa realizar tal medição em um único ponto durante um único período, que em geral corresponde a um ano.

Para a RAA o índice n médio foi obtido a partir de observações e georreferenciamento de usos do solo que possibilitaram descrever o terreno como um todo e como partes isoladas, como pode ser visto na Ilustração 5, obtida a partir de observações de viagens de campo vinculadas ao projeto FAPESP $n^{\circ}$ 03/06441-7, e sua representação em área na Tabela 6, a projeção do índice $n$ para o perfil da curva de velocidades para a RAA é de 0,2 , ou seja, o índice para áreas cultivadas pois a presença maciça de cultivo de cana e consideráveis áreas de cultivo de cítricos, considerando ainda que não haja possibilidade de aproveitamento onde exista mata secundária a fim de evitar maiores degradações ambientais. 


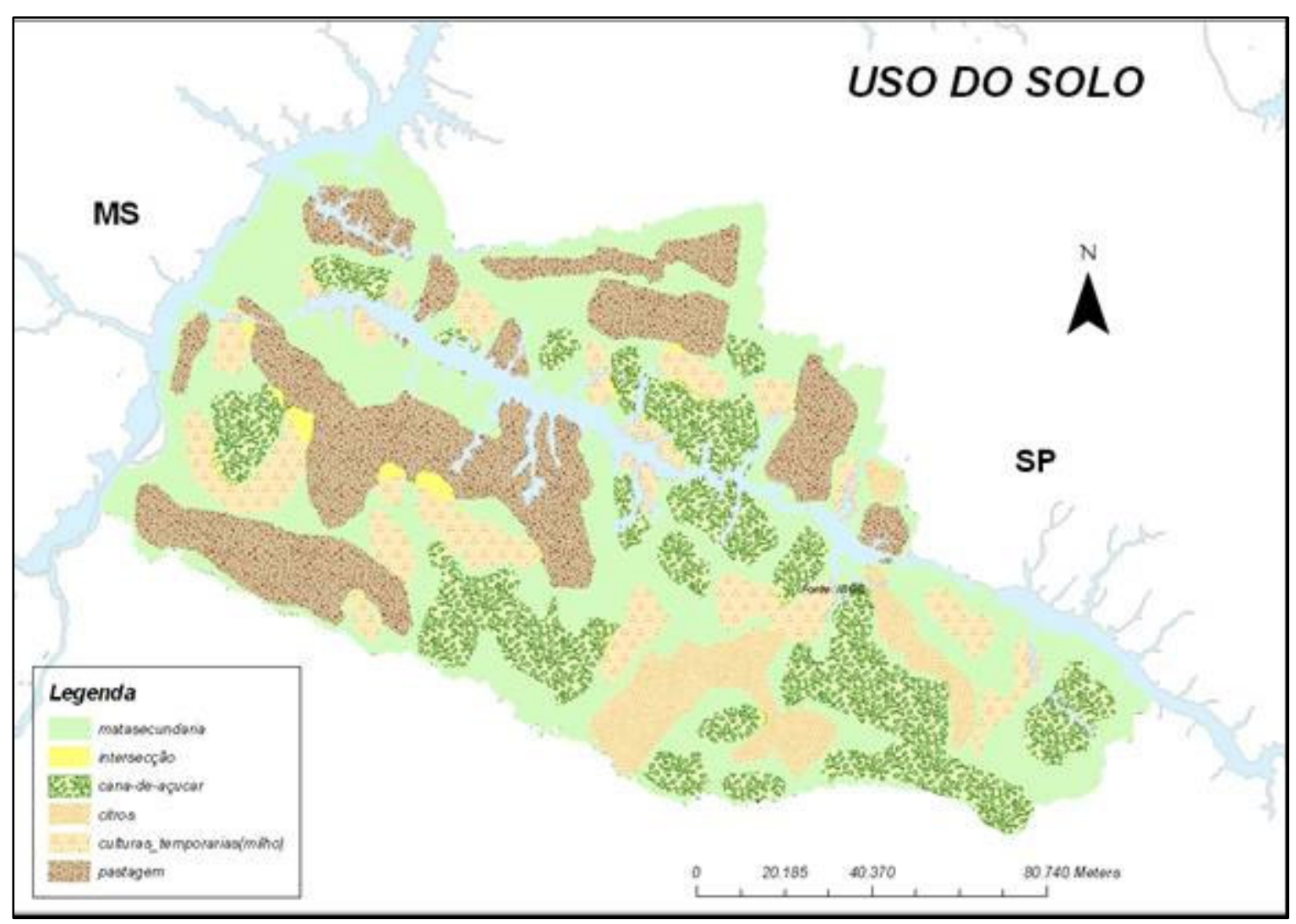

Ilustração 5: distribuição de usos do solo na RAA

Fonte: Elaboração Própria

Tabela 6: distribuição em área do uso do solo na RAA

\begin{tabular}{|c|c|c|c|}
\hline Uso do solo & $\begin{array}{c}\text { Área } \\
\left(\mathrm{km}^{2}\right)\end{array}$ & \multicolumn{2}{|c|}{ Intersecções } \\
\hline & & Milho & Cana-de-açúcar \\
\hline Milho & 2397,52 & - & \\
\hline Cana-de-açúcar & 4214,21 & 33,72 & - \\
\hline Citricos & 1295,89 & 5,71 & \\
\hline Pastagem & 4626,53 & 108,31 & 7,12 \\
\hline Mata secundária & 7155,43 & & \\
\hline Área alagada & 1576,06 & & \\
\hline Total & 20917,43 & & \\
\hline
\end{tabular}

Fonte: Elaboração Própria

A partir destes dados é possível se projetar a velocidade do vento para alturas mais viáveis de aproveitamento da energia eólica, como pode ser visto na Tabela 7. 
Tabela 7: Projeção das velocidades dos ventos para 50m e 100m de altura na RAA

Fonte: Elaboração Própria

\begin{tabular}{|c|c|c|}
\hline $\begin{array}{c}\text { Velocidade } \\
\text { a } 30 \mathrm{~m}(\mathrm{~m} / \mathrm{s})\end{array}$ & $\begin{array}{c}\text { Velocidade a } \\
50 \mathrm{~m}(\mathrm{~m} / \mathrm{s})\end{array}$ & $\begin{array}{c}\text { Velocidade a } \\
100 \mathrm{~m}(\mathrm{~m} / \mathrm{s})\end{array}$ \\
\hline 1 & 1,11 & 1,27 \\
\hline 2 & 2,22 & 2,54 \\
\hline 3 & 3,32 & 3,82 \\
\hline 4 & 4,43 & 5,09 \\
\hline 5 & 5,54 & 6,36 \\
\hline 6 & 6,65 & 7,63 \\
\hline 7 & 7,75 & 8,91 \\
\hline 8 & 8,86 & 10,18 \\
\hline 9 & 9,97 & 11,45 \\
\hline 10 & 11,08 & 12,72 \\
\hline 11 & 12,18 & 13,99 \\
\hline 12 & 13,29 & 15,27 \\
\hline 13 & 14,40 & 16,54 \\
\hline 14 & 15,51 & 17,81 \\
\hline 15 & 16,61 & 19,08 \\
\hline
\end{tabular}

\subsubsection{Potencial Eólico}

O aproveitamento da energia eólica depende primordialmente de um fluxo contínuo de vento com intensidade suficiente para geração energética.

A energia contida neste fluxo é dada por:

$$
P_{E o l}=1 / 2 \rho A v^{3}
$$

Equação 2-11: Potencia Eólica

Onde:

$\rho$ é a densidade característica do ar de 1,225 para $760 \mathrm{~mm}$ de $\mathrm{Hg}$ e $288 \mathrm{~K}\left(15^{\circ} \mathrm{C}\right)$;

A é a área varrida pelas pás do gerador eólico;

$v$ é a velocidade do vento. 
Com o cruzamento dos dados de frequência contida na Tabela 1 com a projeção da velocidade do vento para $50 \mathrm{~m}$ e $100 \mathrm{~m}$ da Tabela 7, é possível calcular o potencial energético por $\mathrm{m}^{2}$ de área de varredura de pás como podemos ver na Tabela 8 e na Tabela 9 , notando que a projeção das velocidades equivalentes a $15 \mathrm{~m} / \mathrm{s}$ em $10 \mathrm{~m}$ que tem freqüência de ocorrência igual a zero na Tabela 1:

Tabela 8: Potencial Eólico por $\mathrm{m}^{2}$ de varredura de pás a $50 \mathrm{~m}$

Fonte: Elaboração Própria

\begin{tabular}{|c|c|c|}
\hline $\begin{array}{c}\text { Velocidade a } \\
50 \mathrm{~m}(\mathrm{~m} / \mathrm{s})\end{array}$ & $\begin{array}{c}\text { Energia } \\
\text { área }\left(\mathrm{W} / \mathrm{m}^{2}\right)\end{array}$ & $\begin{array}{c}\text { Anual por } \\
\text { Área } \\
\left(\mathrm{KWh} / \mathrm{m}^{2}\right)\end{array}$ \\
\hline 3,32 & 44,94 & 32,82 \\
\hline 4,43 & 106,52 & 91,94 \\
\hline 5,54 & 208,04 & 172,61 \\
\hline 6,65 & 359,50 & 233,56 \\
\hline 7,75 & 570,87 & 234,53 \\
\hline 8,86 & 852,15 & 178,95 \\
\hline 9,97 & 1213,31 & 119,92 \\
\hline 11,08 & 1664,35 & 66,85 \\
\hline 12,18 & 2215,25 & 36,18 \\
\hline 13,29 & 2876,00 & 24,45 \\
\hline 14,40 & 3656,58 & 10,36 \\
\hline 15,51 & 4566,98 & 0,76 \\
\hline 16,61 & 5617,19 & 0,00 \\
\hline
\end{tabular}


Tabela 9: Potencial Eólico por $\mathrm{m}^{2}$ de varredura de pás a 100m

Fonte: Elaboração Própria

\begin{tabular}{|c|c|c|}
\hline $\begin{array}{l}\text { Velocidade a } \\
100 \mathrm{~m}(\mathrm{~m} / \mathrm{s})\end{array}$ & $\begin{array}{l}\text { Energia } \\
\text { anual } \\
\text { por Área } \\
\left(\mathrm{Wh} / \mathrm{m}^{2}\right)\end{array}$ & $\begin{array}{c}\text { Energia } \\
\text { anual por } \\
\text { Área } \\
\left(\mathrm{KWh} / \mathrm{m}^{2}\right)\end{array}$ \\
\hline 3,82 & 68,11 & 101,6678 \\
\hline 5,09 & 161,45 & 284,8217 \\
\hline 6,36 & 315,34 & 534,7023 \\
\hline 7,63 & 544,90 & 723,507 \\
\hline 8,91 & 865,28 & 726,5377 \\
\hline 10,18 & 1291,62 & 554,3546 \\
\hline 11,45 & 1839,04 & 371,4748 \\
\hline 12,72 & 2522,69 & 207,0924 \\
\hline 13,99 & 3357,70 & 112,086 \\
\hline 15,27 & 4359,20 & 75,7288 \\
\hline 16,54 & 5542,34 & 32,09417 \\
\hline 17,81 & 6922,25 & 2,357932 \\
\hline 19,08 & 8514,07 & 0 \\
\hline
\end{tabular}

\subsubsection{Tecnologia e Potencial de aproveitamento}

O aproveitamento da fonte eólica é feito de forma simples, transformando a energia cinética dos ventos que movimentam hélices e que por sua vez fazem girar o eixo de um gerador elétrico. Como a velocidade do vento não pode ser nula ao sair da hélice da turbina eólica, apenas uma fração da energia contida pode ser aproveitada. A fração máxima de aproveitamento mecânico da energia é conhecida por Limite de Betz e é igual a 16/27 (Castro, 2007).

O fator de capacidade da energia é dado pela proporção de energia da potência nominal da turbina que pode ser convertida em energia aproveitável, ou seja, depende da faixa de velocidade de operação a plena carga, do diâmetro das pás e também da probabilidade de ocorrência de ventos dentro da faixa de operação.

O Potencial máximo de aproveitamento deve levar em conta o Limite de Betz, o fator de capacidade associado à melhor tecnologia e a distribuição ótima de turbinas na região, 
considerando que um gerador deve sempre guardar considerável distância para outro gerador para que a turbulência gerada neste não tenha maiores influências na geração do outro. $\mathrm{O}$ usual de uma distribuição criteriosa é o resguardo de uma distância 5 a 9 vezes o tamanho do diâmetro da turbina na direção predominante do vento e de 3 a 5 vezes na direção perpendicular

Para a RAA, o potencial máximo de aproveitamento deve levar em conta a área possível de instalação de fazendas eólicas, considerando o máximo de cerca de 1,5\% da área cultivada, dada na Tabela 6 , no total de $190 \mathrm{Km}^{2}$.

Utilizando-se de turbinas de 100 metros de altura e 60 de diâmetro, a distribuição na área considerada permite a instalação de aproximadamente 1900 turbinas, que para a distribuição de probabilidade da velocidade dos ventos na região e disponibilidade geral de áreas possíveis de implantação, têm as características apresentadas na Tabela 10.

Tabela 10: potência e energia por turbina de $1500 \mathrm{~kW}$ e fator de capacidade

\begin{tabular}{|c|c|c|c|}
\hline $\begin{array}{c}\text { Velocidade } \\
\text { do Vento }\end{array}$ & $\begin{array}{c}\text { pot } \\
\text { turbina }\end{array}$ & disponível & $\begin{array}{c}\text { energia } \\
\text { por } \\
\text { turbina } \\
\text { Max(kWh) }\end{array}$ \\
\hline 3 & 192,5837 & 192,5837 & 287458,8 \\
\hline 4 & 456,4946 & 456,4946 & 805314,3 \\
\hline 5 & 891,5911 & 891,5911 & 1511835 \\
\hline 6 & 1540,669 & 1500 & 1991668 \\
\hline 7 & 2446,526 & 1500 & 1259482 \\
\hline 8 & 3651,957 & 1500 & 643792 \\
\hline 9 & 5199,759 & 1500 & 302991 \\
\hline 10 & 7132,729 & 1500 & 123138 \\
\hline 11 & 9493,662 & 1500 & 50072,71 \\
\hline 12 & 12325,36 & 1500 & 26058,25 \\
\hline 13 & 15670,61 & 1500 & 8686,083 \\
\hline 14 & 19572,21 & 1500 & 510,9461 \\
\hline 15 & 24072,96 & 1500 & 0 \\
\hline & total & & $\mathbf{7 0 1 1 0 0 7}$ \\
\hline & FC & & $\mathbf{5 3 \%}$ \\
\hline
\end{tabular}


Notar que o fator de capacidade depende de uma escolha criteriosa da potência do gerador, podendo-se optar por uma diminuição do FC e aumento da potência disponível por turbina para aproveitamento do total da energia nas maiores velocidades ou diminuir a máxima geração para que se distribua no máximo do tempo.

Para as características acima escolhidas e suas possibilidades de instalação já descritas, o potencial eólico realizável da região é de 13.215 GWh por ano.

\subsubsection{Cômputo e Valoração do Potencial Completo Eólico}

O CVPC é uma ferramenta utilizada com o intuito de se caracterizar tanto os RELOs quanto os RELDs de forma individual nas quatro dimensões de análise do PIR porém com a possibilidade de se realizar uma comparação par-a-par entre eles. Para tal, é necessário que, dentro das dimensões ambiental, social, política e técnico-econômica se definam sub-atributos que serão valorados individualmente em cada recurso.

A valoração do recurso não é necessariamente um valor discreto e mensurável, pois muitos dos sub-atributos considerados são subjetivos ou descritivos. Porém é necessário que se defina, para estes casos, escalas de normalização descritiva.

A realização apropriada do CVPC permite, como será visto mais a frente, que se obedeça com maior facilidade as possíveis barreiras impostas pelo mapeamento energoambiental, além de possibilitar uma diferente gama de análises dentro dos cenários energéticos quando se possibilita a análise de parâmetros não apenas técnico econômicos.

O CVPC de todos os recursos é analisado da perspectiva exclusiva de operação, sem considerar ciclo de vida de combustíveis e materiais, transporte e distribuição e outros fatores não pertinentes à operação. 
Para o RELO eólico, o CVPC ficou assim definido:

\section{Dimensão Técnico-Econômica:}

Fator de Capacidade: é o fator relativo entre a máxima energia e a efetivamente gerada durante um ano.

Para o RELO eólico da RAA definido anteriormente, a máxima energia seria se os $1500 \mathrm{~kW}$ por turbina fossem gerados em todas as 8760 horas do ano. Como isto não acontece por fatores de intermitência do vento, eficiência mecânica e elétrica, e paradas para manutenção, o FC para a RAA é de 53\%

Domínio da Tecnologia: representa quem é o portador da tecnologia implantada. Esta pode ser nacional, mista ou inteiramente importada.

Para o RELO eólico a tecnologia é nacional, lembrando que a análise aqui se faz apenas no domínio tecnológico e não se este é mais interessante econômica ou tecnicamente.

Equipamento e Material: descrição da procedência de equipamentos, peças de reposição e manutenção. Pode ser nacional, mista ou importada.

Para o RELO eólico equipamentos e material é nacional.

Tempo de Implantação: o tempo de implantação é o tempo total considerado apenas da construção do empreendimento energético. É mensurado em meses.

Para o RELO eólico o tempo de implantação é de 24 meses 
Qualificação da Mão-de-obra: é o descritivo do nível de qualificação necessário para montagem, operação e manutenção do recurso. É dividido em sem qualificação, técnico e especializado.

Para o RELO eólico a qualificação de mão-de-obra deve ser especializada.

Disponibilidade de Fornecimento: refere-se à possibilidade de obtenção de equipamento para a instalação do recurso. Se os equipamentos podem ser obtidos de forma comercial, sob encomenda ou se a tecnologia existe, mas não é fabricado.

Para o RELO eólico a disponibilidade é sob encomenda.

Custo de Implantação: é o custo total do empreendimento dividido por sua potência, dado em $\mathrm{R} \$ / \mathrm{kW}$.

Para o RELO eólico o custo de implantação é de R \$ 2200,00 por kW.

Tempo de Retorno: é o tempo necessário para que o investimento para implantar o recurso retorne. É calculado pelo payback simples, sem desconto de desvalorização de capital e é dado em anos.

Para o RELO eólico o tempo de retorno é de 5 anos considerando tarifas para o proinfa.

Custos de Operação e Manutenção: o custo de operação refere-se à potência instalada, independente de outros fatores, já o custo de manutenção depende do tempo de operação e da energia gerada. $\mathrm{O}$ custo de operação é dado em $\mathrm{R} \$ / \mathrm{kW}$ e o de manutenção é dado em R $\$$ MWh 
Para o RELO eólico: o custo de operação é de $\mathrm{R} \$ 46,00$ por $\mathrm{kW}$ instalado e de R $\$$ 0,06 por MWh gerado.

Vida Útil: geralmente a vida útil de um recurso é utilizada para determinar parâmetros econômicos inerentes ao empreendimento, podendo ser excedido ou encurtado por fatores técnicos.

Para o RELO eólico a vida útil é de 20 anos

\section{Dimensão Ambiental}

Meio Terrestre

Dejetos Sólidos: Quantidade de poluentes sólidos gerados durante a geração de energia elétrica, medido em peso por potência gerada.

Para o RELO eólico não há geração de dejetos sólidos.

Dejetos Líquidos: São todos os poluentes passíveis de infiltração do solo por vazamentos, depósito ou despejo. Valorado pelo tipo de poluente e volume emitido por potência gerada.

Para o RELO eólico não há geração de dejetos líquidos

Ocupação do Solo: área de ocupação do empreendimento energético por sua potência instalada, ou densidade de potência por área.

Para o RELO eólico a ocupação é de $14,88 \mathrm{~W} / \mathrm{m}^{2}$. 
Meio Aquático

Consumo de Água: volume de água consumida necessária na geração da energia.

Para o RELO eólico não há consumo de água

Emissão de Poluentes: volume de poluentes emitidos nos corpos d'água da RAA provenientes da geração de energia.

Para o RELO eólico não há emissão de poluentes.

Demanda de Oxigênio - DBO e DQO: quantidade de poluentes contidos na água que consomem o oxigênio através de oxidação ou respiração aeróbia.

Para o RELO eólico não há influência na demanda de oxigênio, seja DBO ou DQO

Variação de Temperatura: variação da temperatura dos corpos d'água modificada para a geração de energia pelo recurso, relacionada à manutenção do ecossistema.

Para o RELO eólico não há variação de temperatura.

Alteração do $\mathbf{p H}$ :alteração do índice de $\mathrm{pH}$ dos corpos d'água devido à implantação do recurso.

Para o RELO eólico não há alteração do pH.

Alteração do Volume de Escoamento: mudança volume de deslocamento de água ocasionada pelo recurso.

Para o RELO eólico não há alterações do volume de escoamento. 
Meio Aéreo

Poluentes Atmosféricos Gasosos: volume de gases poluentes emitidos na atmosfera causado pela energia gerada pelo recurso.

Para o RELO eólico não há emissão de poluentes atmosféricos gasosos.

Material Particulado: volume de materiais particulados emitidos na atmosfera durante a geração de energia.

Para o RELO eólico não há emissão de MP.

Gases do Efeito Estufa: emissão de gases de efeito estufa, em volume, através da metodologia do IPCC de $\mathrm{CO}_{2}$ equivalente.

Para o RELO eólico não há emissão de $\mathrm{CO}_{2}$ equivalente durante a geração de energia.

Degradantes da Camada de Ozônio: volume de gases prejudiciais à camada de ozônio emitidos na atmosfera durante a geração de energia.

Para o RELO eólico não geração de degradantes de camada de ozônio.

\section{Dimensão Social}

Geração de Empregos

Construção: quantidade de empregos gerados durante a fase de construção do empreendimento. Relativo à potencia instalada.

Para o RELO eólico são gerados 2,30 empregos por MW instalado. 
Operação: quantidade de empregos gerados durante a fase de operação do empreendimento. Relativo à potencia instalada.

Para o RELO eólico são gerados 0,13 empregos por MW instalado.

Percepção de Conforto

Quanto o recurso altera a estética, aplicação funcional e conforto.

Para o RELO eólico há mudanças na paisagem e poluição sonora.

Impacto Humano Decorrente do Espaço Ocupado

Pessoas Deslocadas ou Lesadas: quantidade de pessoas que deverão ser deslocadas para construção e/ou operação do RELO.

Para o RELO eólico há uma pequena diminuição do espaço para habitação decorrente da infra estrutura de instalação.

Existência de Sítios Arqueológicos e Históricos: consideração dos níveis e tipos de impactos causados pelo recurso em possíveis sítios existentes nos locais de implantação.

Para o RELO eólico a ocupação de áreas médias pela infraestrutura podem afetar sítios arqueológicos na RAA.

\section{Dimensão Política}

Apoio Governamental

Apoio Político: possibilidade de utilização do recurso como lobby político ou suporte a políticas públicas. 
Para o RELO eólico há apoio político para diversificação limpa da matriz energética.

Incentivos fiscais: Determinação de incentivos financeiros e tributários para a implantação do recurso.

Para o RELO eólico há incentivos de programa de fontes alternativas.

Propriedade do recurso

Fonte: a fonte energética pode advir da própria região, de outros estados ou países e ser de posse estatal, privada ou pública.

Para o RELO eólico a fonte é regional e livre.

Variação Cambial: determina a vulnerabilidade do recurso à cenários externos de enfraquecimento da moeda.

Para o RELO eólico há muita vulnerabilidade cambial.

Aceitação do Recurso

\section{Grandes Consumidores}

Para o RELO eólico, a média potência e tecnologia em desenvolvimento dificultam o gerenciamento e planejamento além de implicar em encarecimento da energia.

\section{Distribuidores}

Para o RELO eólico, a média potência e tecnologia em desenvolvimento dificultam o gerenciamento e planejamento além de implicar em encarecimento da energia. 


\section{Geradores}

Para o RELO eólico, a média potência e tecnologia em desenvolvimento dificultam o gerenciamento e planejamento além de implicar em encarecimento da energia.

\section{ONGs}

Para o RELO eólico há uma boa aceitação pela possibilidade de aproveitamento de fontes limpas de energia.

\section{População}

Para o RELO eólico há aceitação por ser energia limpa, apesar de custosa.

Motivação dos Agentes: motivação dos agentes para apoiar ou refutar a utilização do recurso de forma econômica.

\section{Grandes Consumidores}

Para o RELO eólico, a média potência e tecnologia em desenvolvimento dificultam o gerenciamento e planejamento além de implicar em encarecimento da energia.

\section{Distribuidores}

Para o RELO eólico, a média potência e tecnologia em desenvolvimento dificultam o gerenciamento e planejamento além de implicar em encarecimento da energia.

\section{Geradores}

Para o RELO eólico, a média potência e tecnologia em desenvolvimento dificultam o gerenciamento e planejamento além de implicar em encarecimento da energia. 


\section{ONGs}

Para o RELO eólico há uma boa aceitação pela possibilidade de aproveitamento de fontes limpas de energia.

\section{Sociedade Organizada}

Para o RELO eólico há aceitação por ser energia limpa.

\section{Governo}

Para o RELO eólico há a possibilidade de interesse em segurança energética e qualificação da matriz como renovável e sustentável.

\subsection{Energia Solar}

A energia solar se caracteriza pela radiação proveniente do sol. Esta radiação, quando atinge a atmosfera é parcialmente refletida e absorvida, além de mudanças de espectro e difusão, dependendo estes fatores do ângulo zenital do sol e das características meteorológicas.

\subsubsection{Radiação Solar}

A potência da radiação solar incidente é medida em Watts por Metro quadrado, é a informação mais importante para o levantamento do potencial de energia solar. Seja para um aproveitamento fotoelétrico ou térmico.

A medição na RAA é feita através do sistema meteorológico do projeto FAPESP por um piranômetro modelo CMP3, que consiste em um sensor thermopile dentro de uma cúpula ligada a um cabo. O themopile é coberto com uma camada absorvente preta. A tinta absorve a 
radiação e a converte em calor. A diferença de temperatura resultante é convertida em tensão pelo sistema de cobre do thermopile. O thermopile é encapsulado de tal modo que o campo de visão seja de $180^{\circ}$ e as suas características angulares cumprem as exigências de resposta de medição.

Com a conversão direta de potência em tempo, é possível se obter diretamente a média diária de energia por $\mathrm{m}^{2}$ na RAA, como pode ser observado mês a mês na Ilustração 6 e na Tabela 11.

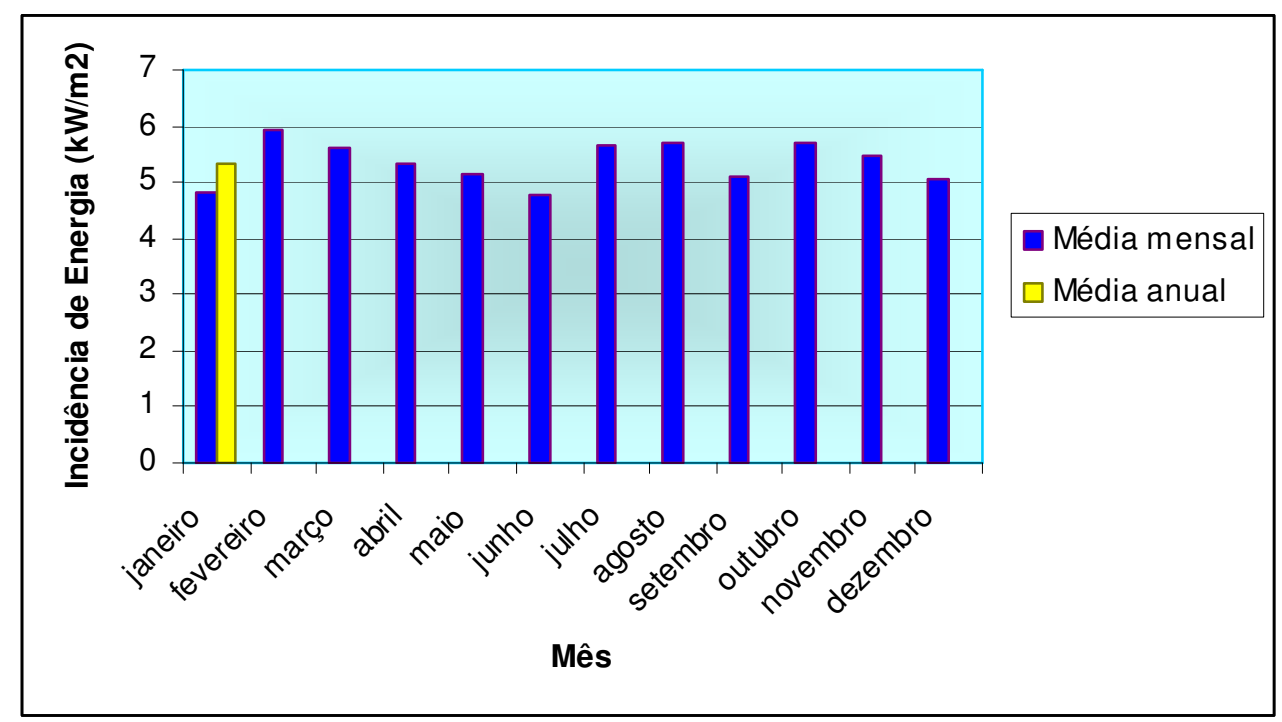

Ilustração 6: Gráfico da média de energia incidente $\left(\mathrm{kW} / \mathrm{m}^{2}\right)$

Fonte: Elaboração Própria a partir de dados da estação meteorológica da RAA em conjunto com dados do CRESESB 
Tabela 11: média de energia por metro quadrado incidente de radiação solar

\begin{tabular}{|c|c|c|}
\hline mês & $\begin{array}{c}\text { média diária } \\
\left(\mathrm{kWh} / \mathrm{m}^{2 *} \text { dia }\right)\end{array}$ & $\begin{array}{c}\text { total } \\
\left(\mathrm{kWh} / \mathrm{m}^{2}\right)\end{array}$ \\
\hline jan & 4,84 & 150,04 \\
\hline fev & 5,92 & 165,76 \\
\hline mar & 5,6 & 173,6 \\
\hline abr & 5,32 & 159,6 \\
\hline mai & 5,13 & 159,03 \\
\hline jun & 4,77 & 143,1 \\
\hline jul & 5,64 & 174,84 \\
\hline ago & 5,71 & 177 \\
\hline set & 5,09 & 152,7 \\
\hline out & 5,69 & 176,39 \\
\hline nov & 5,46 & 163,8 \\
\hline dez & 5,04 & 156,24 \\
\hline média & 5,35 & 1952,1 \\
\hline
\end{tabular}

Fonte: Elaboração Própria a partir de dados da estação meteorológica da RAA em conjunto com dados do CRESESB

Em aplicação direta da tabela, o potencial anual da fonte solar de energia por metro quadrado é de $1952 \mathrm{kWh} / \mathrm{m}^{2} *$ ano.

\subsubsection{Temperatura}

A temperatura da região é importante informação tanto para aproveitamento fotovoltaico quanto para aquecimento, pois tal informação deve ser levada em conta em projeto de dimensionamento de recursos e mensuração de eficiência térmica.

Para aquecimento por coletores, a temperatura média é importante, pois, como a eficiência de um sistema térmico é dada pela diferença de temperatura de entrada e de saída quanto menor a diferença, maior a eficiência -, é necessário em projeto que se obtenha a melhor eficiência para o aproveitamento sem que haja perdas ou a necessidade de um gasto maior de energia ou de área de captação para compensar as ineficiências deste sistema. 
Para sistemas fotovoltaicos, semicondutores são bastante sensíveis a mudanças de temperatura. Uma temperatura muito alta retira muitos elétrons de sua banda de valência, preenchendo lacunas que estariam livres e aumentando a resistência, e por conseqüência, aumentando a ineficiência de uma transformação fotovoltaica. Assim como uma temperatura muito baixa ocorre justamente o contrário, deixando excessos de lacunas.

A temperatura média é importante para que, a partir de parâmetros de fabricação se possa dimensionar para o ambiente em que se vai utilizar um painel fotovoltaico.

A média anual de temperatura para a RAA é de $27^{\circ} \mathrm{C}$.

\subsubsection{Tecnologia de aproveitamento solar fotovoltaico}

A conversão da energia solar em energia elétrica é feita por semicondutores que, quando irradiados com os espectros da luz solar mais energéticos movimentam as cargas de das impurezas implantadas que são capturados e transformados em carga e, consequentemente, em corrente.

Células solar fotovoltaicas são bastante ineficientes na conversão da energia solar em elétrica, sendo tipicamente de $16 \%$ para células de silício monocristalino, 12,5\% para silício policristalino e pode chegar a $28 \%$ em células de arsenieto de gálio que, contudo, são extremamente caras e não têm viabilidade comercial.

Considerando estas eficiências máximas o potencial para a RAA é de 312,36 $\mathrm{kWh} / \mathrm{m}^{2} *$ ano (UDAETA, 2008).

Levando em conta que há a possibilidade de se utilizar o espaço urbano para aproveitamento sem perda de áreas cultiváveis, a área urbana corresponde a 0,43\% da área total da RAA e é possível utilizar cerca de $10 \%$ da área urbana total e cerca de 0,5\% da área 
total da RAA para instalação de painéis fotovoltaicos a uma ocupação de $25 \%$ com painéis propriamente dito tem-se, através da Ilustração 5 e da Tabela 6 , a área total de $24,73 \mathrm{Km}^{2}$.

Para esta área o potencial técnico máximo é de 7.725 GWh/ano.

\subsubsection{Coletores solares para aquecimento}

Coletores solares, dentro da metodologia do PIR são considerados RELD (Baitelo, 2006), pois são caracterizados por um uso final, o aquecimento de água, a medida de GLD, substituição de energético e o setor de consumo que pode ser aplicado a qualquer um. Com isso, o potencial aqui levantado é o potencial de economia de energia elétrica, considerando que, para a RAA 94,6\% das residências aquecem a água com energia elétrica.

A conversão da energia solar em energia térmica se dá através de placas negras com canículas de cobre por onde passa a água a ser aquecida, podendo ou não haver cobertura de vidro para melhor isolamento térmico e conseqüente aumento na eficiência.

Tendo um coletor solar típico com cobertura de vidro a eficiência de $35 \%$ e ainda o recurso solar, para a RAA tem uma taxa de cobertura de $70 \%$ dos dias são suficientes para aquecimento apropriado da água com energia solar. São dadas algumas informações para o levantamento do potencial técnico máximo de coletores solares

- O número de residências na RAA é de 274.500 com uma média de 3,15 pessoas por residência.

- $66,1 \%$ dos banhos duram menos de 10 minutos e 93,4 duram menos de 20 minutos.

- A potência média de um chuveiro elétrico é de $3200 \mathrm{~W}$.

- A média anual de tempo de uso do chuveiro é de 324 h. 
Com isso têm-se o potencial técnico máximo de conservação de energia através de coletores de 199,2 GWh/ano para a RAA, com um potencial por residência de 1,04 MWh/ano.

\subsubsection{Cômputo e Valoração do Potencial Completo da Energia Solar}

\section{Dimensão Técnico-Econômica:}

\section{Fator de Capacidade:}

Para o RELO solar fotovoltaico é de $16 \%$

Para o RELD coletor solar é de $100 \%$, pois quando um RELD é implantado toda a energia fica disponível todo o tempo. Não cabe aqui comparar o tempo disponível do recurso solar com a eletricidade da qual ele tomou lugar, sendo que esta estará na rede a qualquer tempo.

\section{Domínio da Tecnologia:}

Para o RELO solar fotovoltaico o domínio é estrangeiro.

Para o RELD coletor solar é local.

\section{Equipamento e Material:}

Para o RELO solar fotovoltaico são importados.

Para o RELD coletor solar é local.

\section{Tempo de Implantação:}

Para o RELO solar fotovoltaico é de 0,25 meses 
Para o RELD coletor solar é de 6 meses.

Qualificação da Mão-de-obra:

Para o RELO solar fotovoltaico é sem qualificação.

Para o RELD coletor solar é de qualificação técnica.

Disponibilidade de Fornecimento:

Para o RELO solar fotovoltaico é comercial.

Para o RELD coletor solar é comercial.

Custo de Implantação:

Para o RELO solar fotovoltaico é de R $\$ 2500,00 / \mathrm{kW}$ instalado.

Para o RELD coletor solar é de R\$ 2,16 /kWh *ano.

Tempo de Retorno:

Para o RELO solar fotovoltaico é de 10 anos.

Para o RELD coletor solar é de 2 anos.

Custos de Operação e Manutenção:

Para o RELO solar fotovoltaico é de $\mathrm{R} \$ 20,00 / \mathrm{kW}$ instalado.

Para o RELD coletor solar não há custo de O\&M. 


\section{Vida Útil}

Para o RELO solar fotovoltaico a vida útil é de 15 anos.

Para o RELD coletor solar a vida útil é de 20 anos.

\section{Dimensão Ambiental}

Meio Terrestre

Dejetos Sólidos:

Para o RELO solar fotovoltaico não há dejetos sólidos.

Para o RELD coletor solar não há dejetos sólidos.

Dejetos Líquidos:

Para o RELO solar fotovoltaico não há dejetos líquidos.

Para o RELD coletor solar não há dejetos líquidos.

Ocupação do Solo:

Para o RELO solar fotovoltaico a ocupação do solo é de $19,7 \mathrm{~W} / \mathrm{m}^{2}$.

Para o RELD coletor solar a ocupação do solo é zero pois utiliza instalações já existentes.

Meio Aquático 


\section{Consumo de Água:}

Para o RELO solar fotovoltaico há consumo desprezível de água para limpeza dos painéis, pois se considera apenas a operação.

Para o RELD coletor solar há consumo desprezível de água, pois se considera o uso final e não a forma de utilização (apenas o calor para aquecer a água e não a água aquecida).

\section{Emissão de Poluentes:}

Para o RELO solar fotovoltaico não há emissão de poluentes.

Para o RELD coletor solar não há emissão de poluentes.

Demanda de Oxigênio - DBO e DQO:

Para o RELO solar fotovoltaico não há demanda.

Para o RELD coletor solar não há demanda.

\section{Variação de Temperatura}

Para o RELO solar fotovoltaico não há variação.

Para o RELD coletor solar não há variação.

\section{Alteração do $\mathrm{pH}$}

Para o RELO solar fotovoltaico não há alteração do pH.

Para o RELD coletor solar não há alteração do pH. 
Alteração do Volume de Escoamento

Para o RELO solar fotovoltaico não há alteração volume de escoamento.

Para o RELD coletor solar não há alteração do volume de escoamento.

Meio Aéreo

Poluentes Atmosféricos Gasosos:

Para o RELO solar fotovoltaico não há emissão de poluentes atmosféricos gasosos.

Para o RELD coletor solar não há emissão de poluentes atmosféricos gasosos.

Material Particulado:

Para o RELO solar fotovoltaico não há emissão de MP.

Para o RELD coletor solar não há emissão de MP.

Gases do Efeito Estufa:

Para o RELO solar fotovoltaico não há emissão de $\mathrm{CO}_{2}$ equivalente durante a geração de energia.

Para o RELD coletor solar não há emissão de $\mathrm{CO}_{2}$ equivalente durante a geração de energia.

Degradantes da Camada de Ozônio:

Para o RELO solar fotovoltaico não há geração de degradantes de camada de ozônio.

Para o RELD coletor solar não há geração de degradantes de camada de ozônio. 


\section{Dimensão Social}

Geração de Empregos

\section{Construção:}

Para o RELO solar fotovoltaico é de 0,78 empregos por MW instalado.

Para o RELD coletor solar 0,025 empregos por MW instalado.

\section{Operação}

Para o RELO solar fotovoltaico é de 0,07 empregos por MW instalado.

Para o RELD coletor solar não há empregos gerados durante a operação.

Percepção de Conforto

Para o RELO solar fotovoltaico há pequenas mudanças na arquitetura local.

Para o RELD coletor solar há pequenas mudanças na arquitetura local.

\section{Impacto Humano Decorrente do Espaço Ocupado}

Pessoas Deslocadas ou Lesadas:

Para o RELO solar fotovoltaico não ocorre.

Para o RELD coletor solar não ocorre.

\section{Existência de Sítios Arqueológicos e Históricos:}

Para o RELO solar fotovoltaico não afeta. 
Para o RELD coletor solar não afeta.

\section{Dimensão Política}

Apoio Governamental

Apoio Político

Para o RELO solar fotovoltaico há apoio para comunidades isoladas objetivando a universalização da energia

Para o RELD coletor solar há pouco apoio político.

Incentivos fiscais:

Para o RELO solar fotovoltaico não há.

Para o RELD coletor solar há a possibilidade de legislação em favor da utilização.

Propriedade do recurso

Fonte:

Para o RELO solar fotovoltaico a fonte é regional e livre.

Para o RELD coletor solar a fonte é regional e livre.

\section{Variação Cambial:}

Para o RELO solar fotovoltaico há muita influência da variação cambial.

Para o RELD coletor solar não há influência da variação cambial. 
Aceitação do Recurso

\section{Grandes Consumidores}

Para o RELO solar fotovoltaico há restrições de ordem gerencial e econômica devido à baixa potência.

Para o RELD coletor solar a aceitação dos grandes consumidores é passiva.

\section{Distribuidores}

Para o RELO solar fotovoltaico há interesse pela universalização de energia, podendo atingir comunidades isoladas.

Para o RELD coletor solar é participativo, pois diminui a necessidade de investimentos em infra estrutura e controles de carga do sistema.

\section{Geradores}

Para o RELO solar fotovoltaico os geradores não se interessam por se tratar de potências e volumes de energia que trazem baixos ganhos econômicos.

Para o RELD coletor solar os geradores são indiferentes.

\section{ONGS}

Para o RELO solar fotovoltaico há uma boa aceitação por parte das ONGs por levar energia a comunidades isoladas e se tratar de energia limpa.

Para o RELD coletor solar há uma ação participativa das ONGs por se tratar de energia limpa e acessível. 


\section{População}

Para o RELO solar fotovoltaico são essenciais a comunidades isoladas e tem boa aceitação por se tratar de energia limpa.

Para o RELD coletor solar tem boa aceitação por se tratar de energia limpa

Motivação dos Agentes:

\section{Grandes Consumidores}

Para o RELO solar fotovoltaico a motivação é restritiva.

Para o RELD coletor solar são indiferentes.

\section{Distribuidores}

Para o RELO solar fotovoltaico possibilidade de utilização em casos isolados em que o diesel é mais oneroso.

Para o RELD coletor solar traz benefícios com a redução de demanda em horário de ponta.

\section{Geradores}

Para o RELO solar fotovoltaico não há interesse.

Para o RELD coletor solar indiferente. 


\section{ONGs}

Para o RELO solar fotovoltaico há boa aceitação para atendimento a comunidades isoladas e opção limpa.

Para o RELD coletor solar há boa aceitação por se tratar de opção limpa e acessível, além de gerar empregos na RAA.

\section{Sociedade Organizada}

Para o RELO solar fotovoltaico há o interesse da sociedade organizada em energias baseadas em fontes renováveis, porém está ligado a um alto investimento inicial.

Para o RELD coletor solar há o interesse na geração de empregos, porém está ligado a um alto investimento inicial.

\section{Governo}

Para o RELO solar fotovoltaico há a possibilidade de cumprimento da universalização da energia.

Para o RELD coletor solar há o interesse na redução da demanda no horário de ponta.

\subsection{Biocombustiveis}

Segundo a ANP, "biocombustíveis são derivados de biomassa renovável que podem substituir, parcial ou totalmente, combustíveis derivados de petróleo e gás natural em motores a combustão ou outro tipo de geração de energia".

Os dois biocombustíveis mais comuns e aqui considerados são o etanol de cana-deaçúcar e o biodiesel proveniente da transesterificação de óleos vegetais e gorduras animais. 


\subsubsection{Produção de Etanol e Potencial Teórico}

É importante assinalar que o presente trabalho apenas trata do potencial referente ao biocombustível em si, sem considerar a biomassa como subproduto dessa energia. Portanto, considerar o excedente de bagaço para produção de energia, apesar de incluso no processo, não será objeto aqui explorado.

A produção da RAA independe do tipo de solo, uma vez que as técnicas atuais permitem a sua correção para atender os requisitos, já o clima da região a torna inteiramente favorável ao cultivo da cana-de-açúcar.

A produção de cana-de-açúcar tem uma eficiência de 300t por hectare

Uma tonelada de cana-de-açúcar produz de 90 a 100 litros de etanol. Considerando um balanço produtivo de cerca de 50\% entre etanol e açúcar, que pode facilmente ser modificado mas serve de regra aos produtores tanto quanto na diversificação dos produtos quanto nas interações de mercado e preço de commodities.

Consultando a Tabela 6 e considerando que a região possui como característica uma dinâmica bastante acelerada de intercâmbio de áreas cultivadas, de acordo com condições de mercado, é possível determinar a máxima área cultivável de cana-de-açúcar para a RAA.

Considerando a área total aproveitável de cerca de 700 mil há, a produção total de etanol para a RAA é de 21 milhões de $\mathrm{m}^{3}$.

O poder calorífico do etanol hidratado é de $6.100 \mathrm{kcal} /$ litro.

Com isso o potencial total do etanol é de $148.000 \mathrm{GWh} /$ ano. 


\subsubsection{Tecnologia de Aproveitamento do Etanol}

Inicialmente a consideração deve ser apenas para a produção de energia elétrica a partir do etanol, sem contar com o que é produzido para ser utilizado como combustível automotivo.

A produção de energia a partir do etanol compartilha a tecnologia utilizada para óleos leves derivados de petróleo, considerando apenas taxas de compressão e velocidade que queima específicos. Podendo ser utilizado para queima direta em motores à combustão ou para produção de vapor em turbinas.

Em condições de mercado equilibrado, a produção do etanol é voltada ao mercado de transporte. Como a consideração do potencial teórico máximo também traz em seu conceito o excedente com objetivo de produzir energia a uma taxa de cerca de $30 \%$ da produção do etanol $^{2}$.

Com uma eficiência máxima de 35\% na conversão de energia e FC de $80 \%$ máximo.

O potencial técnico realizável é de 41.440 GWh/ano

Considerando ainda módulos de $100 \mathrm{~kW}$ de potência de geração, $414 \mathbf{M W h}$ por módulo.

\footnotetext{
${ }^{2}$ Taxa considerando o crescimento da frota de automóveis e da produção do etanol.
} 


\subsubsection{Biodiesel}

O biodiesel para a região está ligado à capacidade de processamento local, sendo possível utilizar como matéria prima para a sua produção oleaginosas que não competem com cana-de-açúcar, ou sebo bovino.

A capacidade de produção é de 100 milhões de litros por ano (UDAETA, 2008).

O poder calorífico do biodiesel é de $9080 \mathrm{kcal} / 1$

O potencial teórico total do biodiesel é de $1056 \mathbf{G W h}$

\subsubsection{Tecnologia de Aproveitamento do Biodiesel}

As tecnologias de aproveitamento do biodiesel são coincidentes com as tecnologias consolidadas para o diesel. Podendo ser utilizado como mistura até $50 \%$ sem qualquer ajuste. Acima desta proporção e até utilizando $100 \%$ de biodiesel, a tecnologia continua a mesma, apenas necessitando pequenos ajustes de funcionamento.

\subsubsection{Cômputo e Valoração do Potencial Completo dos Biocombustíveis}

\section{Dimensão Técnico-Econômica}

Fator de Capacidade:

Para o RELO Etanol para queima direta é de $80 \%$.

Para o RELO Biodiesel é de $80 \%$. 
Domínio da Tecnologia:

Para o RELO Etanol para queima direta o domínio é nacional.

Para o RELO Biodiesel o domínio é nacional.

Equipamento e Material:

Para o RELO Etanol para queima direta, nacional.

Para o RELO Biodiesel são nacionais.

Tempo de Implantação:

Para o RELO Etanol para queima direta é de 1 mês

Para o RELO Biodiesel é de 0,25 meses

Qualificação da Mão-de-obra:

Para o RELO Etanol para queima direta é especializada.

Para o RELO Biodiesel é especializada.

Disponibilidade de Fornecimento:

Para o RELO Etanol para queima direta é sob encomenda.

Para o RELO Biodiesel é comercial.

Custo de Implantação:

Para o RELO Etanol para queima direta é de R\$600,00/kW instalado. 
Para o RELO Biodiesel é de R\$500,00/kW instalado.

Tempo de Retorno:

Para o RELO Etanol para queima direta é de 2 anos.

Para o RELO Biodiesel é de 4 anos.

Custos de Operação e Manutenção:

Para o RELO Etanol para queima direta é de 3\% ao ano do custo de construção para manutenção.

Para o RELO Biodiesel é de $2 \%$ ao ano do custo de construção para manutenção.

\section{Vida Útil}

Para o RELO Etanol para queima direta a vida útil é de 15 anos.

Para o RELO Biodiesel a vida útil é de 40 anos.

\section{Dimensão Ambiental}

\section{Meio Terrestre}

Dejetos Sólidos:

Para o RELO Etanol para queima direta os dejetos sólidos são desprezíveis. 
Para o RELO Biodiesel não há emissões ${ }^{3}$.

Dejetos Líquidos:

Para o RELO Etanol para queima direta os dejetos líquidos são desprezíveis.

Para o RELO Biodiesel não há emissões

Ocupação do Solo:

Para o RELO Etanol para queima direta a ocupação do solo é de $8 \mathrm{~W} / \mathrm{m}^{2}$.

Para o RELO Biodiesel a ocupação do solo é de $8 \mathrm{~W} / \mathrm{m}^{2}$.

Meio Aquático

Consumo de Água:

Para o RELO Etanol para queima direta o consumo de água é de 18 a $20 \mathrm{~m}^{3} / \mathrm{W} / \mathrm{dia}$.

Para o RELO Biodiesel é de $13 \mathrm{~m}^{3} / \mathrm{W} /$ dia.

Emissão de Poluentes:

Para o RELO Etanol para queima direta a emissão de poluentes é desprezível.

Para o RELO Biodiesel não há emissão de poluentes.

${ }^{3}$ Notar que o critério se refere somente à operação da tecnologia com a fonte energética. Portanto, possíveis contabilizações de dejetos na fabricação do biodiesel ou mesmo do etanol não são aqui contabilizados, pois não se trata de um estudo de ciclo de vida. 
Demanda de Oxigênio - DBO e DQO:

Para o RELO Etanol para queima direta não há demanda.

Para o RELO Biodiesel não há demanda.

\section{Variação de Temperatura}

Para o RELO Etanol para queima direta não há variação.

Para o RELO Biodiesel não há variação.

\section{Alteração do $\mathrm{pH}$}

Para o RELO Etanol para queima direta não há alteração do pH.

Para o RELO Biodiesel não há alteração do pH.

\section{Alteração do Volume de Escoamento}

Para o RELO Etanol para queima direta não há alteração volume de escoamento.

Para o RELO Biodiesel não há alteração.

Meio Aéreo

Poluentes Atmosféricos Gasosos:

Para o RELO Etanol para queima direta a emissão de poluentes atmosféricos gasosos é de $0,7 \mathrm{~kg}$ de $\mathrm{NO}_{\mathrm{x}}$ por MWh gerado.

Para o RELO Biodiesel há a emissão de 0,0001 Kg/MWh de $\mathrm{CH}_{4}, 0,033 \mathrm{Kg} / \mathrm{MWh}$ de $\mathrm{SO}_{2}$ e $1,3 \mathrm{Kg} / \mathrm{MWh}$ de $\mathrm{NO}_{\mathrm{x}}$. 
Material Particulado:

Para o RELO Etanol para queima direta a e emissão de MP é menor que $0,1 \mathrm{Kg}$ por MWh gerado.

Para o RELO Biodiesel há a emissão de 0,17 Kg/MWh.

Gases do Efeito Estufa:

Para o RELO Etanol para queima direta a emissão de $\mathrm{CO}_{2}$ equivalente durante a geração de energia é de $600 \mathrm{Kg} / \mathrm{MWh}$.

Para o RELO Biodiesel a emissão de $\mathrm{CO}_{2}$ equivalente durante a geração é de 888 $\mathrm{Kg} / \mathrm{MWh}$

\section{Degradantes da Camada de Ozônio:}

Para o RELO Etanol para queima direta não há indícios de degradantes de camada de ozônio.

Para o RELO Biodiesel não há indícios.

\section{Dimensão Social}

Geração de Empregos

\section{Construção:}

Para o RELO Etanol para queima direta é de 0,8 empregos por MW instalado.

Para o RELO Biodiesel é de 0,77 empregos por MW instalado. 


\section{Operação}

Para o RELO Etanol para queima direta é de 0,29 empregos por MW instalado.

Para o RELO Biodiesel é de 0,25 empregos por MW instalado.

Percepção de Conforto

Para o RELO Etanol para queima direta há aumento do tráfego de veículos pesados, fuligem e grandes instalações físicas.

Para o RELO Biodiesel há aumento do tráfego de veículos pesados, fuligem e instalações físicas médias.

Impacto Humano Decorrente do Espaço Ocupado

Pessoas Deslocadas ou Lesadas:

Para o RELO Etanol para queima direta decorre do cultivo intensivo de cana-deaçúcar e infraestrutura ao redor.

Para o RELO Biodiesel não há pessoas deslocadas.

Existência de Sítios Arqueológicos e Históricos:

Para o RELO Etanol para queima direta a infraestrutura pode afetar sítios arqueológicos.

Para o RELO Biodiesel infraestrutura pode afetar sítios arqueológicos. 


\section{Dimensão Política}

Apoio Governamental

Apoio Político

Para o RELO Etanol para queima direta, apesar da competição com energias mais limpas e eficientes há forte apoio político.

Para o RELO Biodiesel há forte apoio à produção e incentivo à comercialização.

Incentivos fiscais:

Para o RELO Etanol para queima direta há possibilidades para pequenas instalações.

Para o RELO Biodiesel é provável para pequenas e médias instalações.

\section{Propriedade do recurso}

Fonte:

Para o RELO Etanol para queima direta a fonte é regional e privada.

Para o RELO Biodiesel a fonte é regional e privada

\section{Variação Cambial:}

Para o RELO Etanol para queima direta há influência limitada à variação cambial.

Para o RELO Biodiesel a influência da variação cambial é limitada. 
Aceitação do Recurso

\section{Grandes Consumidores}

Para o RELO Etanol para queima direta, apesar do encarecimento da energia ofertada, a presença do setor na RAA favorece o recurso.

Para o RELO Biodiesel, apesar de incentivos é dificultado pelo preço da energia.

\section{Distribuidores}

Para o RELO Etanol para queima direta o encarecimento da energia ofertada cria dificuldades à sua comercialização.

Para o RELO Biodiesel há a possibilidade de utilização em comunidades isoladas.

\section{Geradores}

Para o RELO Etanol para queima direta a opção de geração com baixo custo de implantação pode ser uma opção, apesar do encarecimento da energia.

Para o RELO Biodiesel há a preferência por geração de potências mais altas.

\section{ONGs}

Para o RELO Etanol para queima direta as ONGs são favoráveis por se tratar de energia renovável, contudo o apoio é essencialmente a baixas potências.

Para o RELO Biodiesel há apoio à produção vinda de cultura familiar.

\section{População}


Para o RELO Etanol para queima direta, a população em geral se mostra favorável.

Para o RELO Biodiesel a população se mostra indiferente.

Motivação dos Agentes:

\section{Grandes Consumidores}

Para o RELO Etanol para queima direta, apesar do encarecimento da energia ofertada, a presença do setor na RAA favorece o recurso.

Para o RELO Biodiesel há problemas de gerenciamento e econômicos devido ao preço e às baixas potências.

\section{Distribuidores}

Para o RELO Etanol para queima direta o encarecimento da energia ofertada cria dificuldades à sua comercialização.

Para o RELO Biodiesel há a preferência pelo diesel tradicional, mais barato

\section{Geradores}

Para o RELO Etanol para queima direta a opção de geração com baixo custo de implantação pode ser uma opção, apesar do encarecimento da energia.

Para o RELO Biodiesel há interesse por formas de geração de potências mais elevadas.

\section{ONGS}

Para o RELO Etanol para queima direta, as ONGs apóiam o recursos por se tratar de fonte renovável. 
Para o RELO Biodiesel há a geração de energia com fonte renovável e criação de empregos em agricultura familiar.

\section{Sociedade Organizada}

Para o RELO Etanol para queima direta o aumento da energia é o principal obstáculo.

Para o RELO Biodiesel a competição com energias renováveis mais limpas são um obstáculo.

\section{Governo}

Para o RELO Etanol para queima direta apesar de tecnologias mais eficientes, o governo tem interesse em promover a utilização do etanol.

Para o RELO Biodiesel há interesse em promoção para criação de empregos em agricultura familiar.

\section{Previsão de demanda a Partir da Composição de Cenários}

\subsection{Cenários Energéticos}

Um cenário energético é uma visão futura de condições que, ao construir-se tal cenário, adotam-se como passos no horizonte de planejamento. Não necessariamente uma projeção das condições passadas e presentes do sistema, região ou país a que se aplicam, mas uma possibilidade de estudar como determinadas variáveis afetam o planejamento e as medidas que, tomadas em determinadas situações e determinados intervalos de tempo fazem do planejamento feito um caminho robusto e com menores incertezas. 
Os cenários energéticos são construídos com o objetivo de analisar a consistência do planejamento realizado ao longo de seu horizonte de tempo, verificando se os recursos energéticos em estudo atendem às necessidades ao longo do tempo e em períodos particulares do planejamento.

Dentro do PIR esse trabalho é feito com o intuito de validar o Plano Integrado de Recursos Energéticos, ao se modelar demandas, impactos ambientais, sociais e econômicos resultantes do planejamento proposto (Gimenes, 2004).

Um cenário energético está intimamente ligado a um cenário sócio-econômico no qual ele é construído em cima e a partir deste. Essa ligação se traduz em uma mudança das próprias condições sociais e econômicas a partir do cenário energético analisado, proporcionando uma verificação interativa e iterativa das premissas do cenário tendencial.

Para um determinado cenário sócio-econômico pode se satisfazer a demanda energética de diferentes formas, considerando diferentes fontes e variadas formas de usos finais. Essas diferenças podem refletir-se na estrutura tarifária, nas leis em que se enquadram o uso do energético ou mesmo na quantidade de energia necessária para se atender a um determinado serviço energético (Bravo, 2008).

Em um país em desenvolvimento, como é o caso do Brasil, tanto em uma análise federativa, como apenas se pensando de forma regional ou local é leviano pensar que uma extrapolação no tempo de dados passados irá responder às demandas energéticas, sociais e estruturais necessárias dentro do planejamento proposto. É necessário que se levante variáveis como crescimento populacional, produto interno, eficiência econômica (que se refere a uma melhor distribuição de renda), nível de eletrificação e distribuição de energéticos, acesso a novas tecnologias, estruturas regulatórias e crescimento da infra-estrutura. 


\subsection{Horizonte de Planejamento}

As condições de planejamento de curto e médio prazo estão intimamente ligadas às condições presentes do sistema em questão. Para que não se transforme apenas em um trabalho descritivo, o planejamento e a construção de cenários energéticos devem considerar uma análise de longo prazo, superior a 15 anos.

Deve se ressaltar que, em um horizonte de longo prazo, regredir a anos intermediários pode ser discrepante de compor e somar cenários de curto e médio prazo, mas tais discrepâncias devem ser utilizadas para definir possíveis mudanças que levarão da situação presente à considerada (Bravo, 2008).

\subsection{Cenários Sócio-Econômicos}

Um cenário energético e todo o planejamento a que ele está sujeito depende intimamente do cenário sócio-econômico traçado para o horizonte de análise, sendo um processo interativo entre políticas energéticas e sociais.

Para a composição de cenários sócio-econômicos, é necessário que, dentro das variáveis que devem ser levantadas e avaliadas, estejam índices econômicos, sociais, estruturais e geográficos que, juntos podem dar um panorama da região na qual está inserido o cenário em questão.

Quanto maior a estratificação que se faz no cenário de partida, ou o ano base, maiores as possibilidades de composição de cenários alternativos que podem prever intercâmbios de classes sociais, aumento do Produto Interno Bruto per capita, por classe ou setor de atividade. Também é necessário realizar o levantamento do atendimento destes setores de atividade por cada um dos energéticos em questão. (Jannuzi, 2005). 
A consideração de mudanças no cenário mundial ou mesmo em blocos regionais deve ser inclusa na análise do cenário em questão, pois a globalização da economia, competição e cooperação entre regiões econômicas, fluxo de investimentos de grandes mercados influenciam diretamente qualquer prospecção futura.

Assim como cenários contrastados podem cobrir mais possibilidades de acerto ao que se passa no futuro, também abrange um maior número de variáveis que pode inviabilizar o levantamento coerente de dados para responder ao planejamento.

Existem três tipos de cenários.

\section{- Cenários Tendenciais}

Os cenários tendenciais são prolongamentos dos índices históricos e de dados obtidos para a construção do ano base, considerando diretrizes e políticas energéticas seguidas no presente da região, bem como índices de crescimento econômico e de demanda energética.

\section{- Cenários Preditivos}

Cenários preditivos são aqueles em que há a possibilidade de se analisar a interferência de uma ou mais ações conhecidas que devem ser tomadas ao longo do horizonte planejamento.

\section{- Cenários Exploratórios}

Possibilitam modificar a relação entre as variáveis que compõem o sistema e verificar quais os resultados dessa mudança. 


\subsection{Ano Base}

Ano Base compreende o conjunto de dados históricos que compõem a análise do ano inicial em que se assenta a construção de cenários. Esses dados podem ser de um ano de referência ou um conjunto histórico de determinada variável.

A construção do Ano Base resume-se basicamente a prospecção de dados que compõem os cenários a serem analisados, contudo a qualidade desta análise e sua verossimilhança dependem da fonte em que tais dados se baseiam.

\subsubsection{Ano Base para a Região Administrativa de Araçatuba}

A estratificação das informações é uma importante ferramenta para que se possa verificar ao longo do tempo a alteração de comportamentos de consumo ou os efeitos de uma mudança na política energética sobre um determinado uso final. Essa distribuição de critérios de usos energéticos mostra-se, para projeções de longo prazo, de importância determinante para a credibilidade das projeções de análise.

Para a RAA, a demanda foi distribuída basicamente em setores de consumo como residencial, comercial, público e Industrial, trazendo dentro de cada um dos setores subestratificações de acordo com o setor como, por exemplo, dentro do setor residencial, se estratificam em eletrificado e não eletrificado, e dentro desta estratificação dividida em 3 classes de distribuição de renda. Após a estratificação completa dos sub-setores é feita a estratificação em usos finais e, por fim, os energéticos utilizados e sua intensidade ao longo de um ano. 


\subsection{2 Índices de participação setorial e intensidades energéticas}

A distribuição dos usos finais e demandas em ramificações por si só não respondem ao modelo de construção de cenários, necessitando de seus índices de participação em cada setor, sub-setor, uso final ou energético, bem como a sua intensidade energética deve ser determinada.

A distribuição de determinado setor de demanda entre suas sub-estratificações pode ser:

- Saturada, quando um uso final pode ser usado concomitantemente a outro como, por exemplo, 92\% das residências de classe C eletrificada rural do setor residencial contam com algum tipo de refrigeração e ao mesmo tempo 98,2\% dessas residências contam com algum tipo de aquecimento de água.

- Compartilhada, quando uma determinada estratificação, ou uso final é dividida de diversas formas como, por exemplo, do setor residencial eletrificado rural, 58\% são classe C, 39\% são classe B e $3 \%$ são classe A, totalizando $100 \%$

- Unitária, quando o setor em questão é expressado na forma de unidades como, por exemplo, há 274.500 residências na RAA em 2008.

As intensidades energéticas são o consumo energético total anual que um determinado uso final tem dentro da estratificação a que pertence (uma lâmpada incandescente utilizada em uma residência urbana classe $B$ pode ter uma intensidade energética diferente da mesma lâmpada incandescente em um hotel no setor comercial), caracterizando também uma intensidade de demanda reprimida (pois fosse a mesma lâmpada utilizada o mesmo número de horas nos diferentes setores, teria a mesma intensidade energética). 
Para o estudo de caso da RAA, foram cruzados dados do SEADE e do IBGE para a obtenção da participação das classes residenciais, como mostra a Tabela 12.

Tabela 12: Distribuição da população em Residências e Classes Econômicas

\begin{tabular}{|c|c|c|c|c|c|}
\hline & \multicolumn{6}{|c|}{ Por classe Total } \\
\hline & Classe C & Classe B & Classe A & Não Declarado & Total \\
\hline$\%$ & 33 & 58 & 5 & 4 & \\
\hline pop & 287225 & 502568 & 46080 & 31236 & 867109 \\
\hline no de res & 91712 & 157523 & 14872 & 10362 & 274469 \\
\hline
\end{tabular}

\begin{tabular}{|c|c|c|c|c|c|}
\hline & \multicolumn{6}{|c|}{ Por classe Urbano } \\
\hline & Classe C & Classe B & Classe A & Não Declarado & Total \\
\hline$\%$ & 32 & 59 & 6 & 4 & \\
\hline $\mathrm{pop}$ & 260754 & 484913 & 45507 & 30191 & 821364 \\
\hline $\mathrm{n}$ - de res & 83260 & 151989 & 14687 & 10015 & 259951 \\
\hline
\end{tabular}

\begin{tabular}{|c|c|c|c|c|c|}
\hline & \multicolumn{6}{|c|}{ Por classe Rural } \\
\hline & Classe C & Classe B & Classe A & Não Declarado & Total \\
\hline$\%$ & 58 & 39 & 1 & 2 & \\
\hline pop & 26471 & 17655 & 573 & 1046 & 45745 \\
\hline no de res & 8452 & 5534 & 185 & 347 & 14518 \\
\hline
\end{tabular}

\begin{tabular}{|c|c|c|}
\hline Residências & $\%$ & total \\
\hline Urbanas & 95 & 821364 \\
\hline Rurais & 5 & 45745 \\
\hline
\end{tabular}

\begin{tabular}{|c|c|c|}
\hline $\begin{array}{c}\text { Taxa de Crescimento da } \\
\text { população \% }\end{array}$ & 1,5 & 1,35 (limite) \\
\hline população 2008 & 867109 & \\
\hline
\end{tabular}

\begin{tabular}{|c|c|c|c|c|}
\hline \multicolumn{5}{|c|}{ Número de Pessoas por Residência } \\
\hline Classe C & Classe B & Classe A & Sem Declaração & \\
\hline 3,131816506 & 3,190450993 & 3,09841021 & 3,014473568 & \\
\hline
\end{tabular}

Fonte: Elaboração Própria com base em dados do SEADE 2008 e PNAD 2007

As classes de distribuição de renda referem-se a renda em salários mínimos das famílias divididos em três classes, a partir de dados do SEADE (2008).

Sendo da Classe C famílias com renda até 3 salários mínimos, Classe B as famílias com renda de 3 a 20 salários mínimos e Classe A famílias com renda acima de 20 salários mínimos. 
Como se trata de uma análise de consumo e sua projeção no tempo verificou-se que a parcela "Não Declarado" dos dados em análise correspondia, em perfil de usos finais de energia, à classe A, portanto tais perfis foram somados.

Para a obtenção do perfil de uso de eletrodomésticos ou serviços energéticos de acordo com as classes foram cruzadas informações do PNAD (Pesquisa Nacional por Amostras de Domicílios) e do SINPHA (Sistema de Informações de Posses de Eletrodomésticos e Hábitos de Consumo), como pode ser observado na Tabela 13 e na Tabela 14, a exemplo da distribuição de cálculo. A Tabela 13 indica o percentual que cada classe urbana residencial possui de alguns importantes utensílios domésticos consumidores de energia que, dada a sua intensidade energética típica que podem ser dados do Procel, extraídos de estudos consolidados como o SINPHA, ou mesmo dados de placas obtidos por pesquisa in loco em questionários aplicados (UDAETA, 2008), forneceram o total de demanda energética de determinado serviço em um ramo do setor.

Tabela 13: Distribuição de Eletrodomésticos por Classe de Renda

\begin{tabular}{|c|c|c|c|c|}
\hline$\%$ & Classe C & Classe B & Classe A & Não Declarado \\
\hline Urbana & 31,746 & 59,038 & 5,540 & 3,676 \\
\hline Fogão & & & & \\
\hline Tinham & 98,946 & 99,785 & 100,000 & 99,785 \\
\hline Rádio & & & & \\
\hline Tinham & 86,911 & 95,226 & 98,180 & 94,987 \\
\hline Televisão & & & & \\
\hline Tinham & 93,794 & 98,557 & 100,000 & 99,134 \\
\hline Geladeira & & & & \\
\hline Tinham & 94,561 & 99,309 & 100,000 & 99,572 \\
\hline Freezer & & & & \\
\hline Tinham & 2,279 & 19,608 & 51,325 & 68,430 \\
\hline Máquina de lavar roupa & & & & \\
\hline Tinham & 23,994 & 65,077 & 95,800 & 81,221 \\
\hline
\end{tabular}

Fonte: PNAD 2007 
Tabela 14:Potência instalada em lâmpadas e média de uso em residências da Classe C

\begin{tabular}{|c|c|c|c|c|c|}
\hline & & & \multicolumn{3}{|c|}{ Classe C } \\
\hline & \multicolumn{5}{|c|}{ Número de Lâmpadas por domicílio } \\
\hline & & outras & incandescente & fluorescente & total \\
\hline Unidades & & 0,05 & 4,9 & 2,2 & 7,15 \\
\hline \multirow[t]{10}{*}{$\%$} & & 0,6993007 & 68,5 & 30,8 & \\
\hline & $\begin{array}{c}\text { Potência } \\
(\mathrm{W})\end{array}$ & & & & \\
\hline & 15 & & & 0,7 & 10,5 \\
\hline & 20 & & & 0,35 & 7 \\
\hline & 21 & & & 0,71 & 14,91 \\
\hline & 25 & & 0,08 & 0,13 & 5,25 \\
\hline & 40 & & 0,37 & 0,31 & 27,2 \\
\hline & 60 & & 3,74 & & 224,4 \\
\hline & 100 & & 0,66 & & 66 \\
\hline & 150 & & 0,04 & & 6 \\
\hline \multirow[t]{2}{*}{ média de potencia instalada } & & & & & 361,26 \\
\hline & & & & esporádico & Diário \\
\hline Fluorescente & & & potência (W) & 22,74 & 25,32 \\
\hline Incandescente & & & potência (W) & 181,73 & 131,47 \\
\hline \multirow[t]{2}{*}{ KWh/ano } & & & Fluorescente & 2075 & 36963 \\
\hline & & & Incandescente & 16583 & 191952 \\
\hline
\end{tabular}

Fonte: SINPHA 2006

Alguns cruzamentos de dados são necessários quando se tem uma relação de dados que trazem a informação da forma que o ano base pede, ou essa informação pode ser relativizada para que se aplique a outra fonte de dados (como pode ser observado na Tabela 15). Assim o foi utilizado para que, se observando a fonte "Brasil ano 2000" pudesse se enxergar A RAA ano 2008. 
Tabela 15: Relativização de uso de energéticos para cocção - Brasil

\begin{tabular}{|c|c|c|c|c|c|}
\hline Classe C & absoluto & $\%$ do total & $\%$ da Classe & $\%$ da Zona & Até 5 \\
\hline Total & 2.385 .157 & 29,665 & & & \multirow{3}{*}{ Total } \\
\hline Urbana & 2.066 .123 & 25,697 & 86,62 & & \\
\hline Rural & 319.034 & 3,968 & 13,38 & & \\
\hline Total & 24.699 & 0,307 & 1,04 & & \multirow{3}{*}{ Gás canalizado } \\
\hline Urbana & 24.384 & 0,303 & 1,02 & 1,18 & \\
\hline Rural & 315 & 0,004 & 0,01 & 0,10 & \\
\hline Total & 2.092 .903 & 26,030 & 87,75 & & \multirow{3}{*}{ Só gás de botijão } \\
\hline Urbana & 1.948 .335 & 24,232 & 81,69 & 94,30 & \\
\hline Rural & 144.568 & 1,798 & 6,06 & 45,31 & \\
\hline Total & 47.098 & 0,586 & 1,97 & & \multirow{3}{*}{ Só lenha } \\
\hline Urbana & 12.640 & 0,157 & 0,53 & 0,61 & \\
\hline Rural & 34.458 & 0,429 & 1,44 & 10,80 & \\
\hline Total & 196.958 & 2,450 & 8,26 & & \multirow{3}{*}{ Gás de botijão e lenha } \\
\hline Urbana & 59.267 & 0,737 & 2,48 & 2,87 & \\
\hline Rural & 137.691 & 1,713 & 5,77 & 43,16 & \\
\hline Total & 153 & 0,002 & 0,01 & & \multirow{3}{*}{ Carvão } \\
\hline Urbana & 106 & 0,001 & 0,00 & 0,01 & \\
\hline Rural & 47 & 0,001 & 0,00 & 0,01 & \\
\hline Total & 1.206 & 0,015 & 0,05 & & \multirow{3}{*}{ Outro } \\
\hline Urbana & 1.022 & 0,013 & 0,04 & 0,05 & \\
\hline Rural & 184 & 0,002 & 0,01 & 0,06 & \\
\hline Total & 22.140 & 0,275 & 0,93 & & \multirow{3}{*}{$\begin{array}{l}\text { Não tinham fogão ou } \\
\text { fogareiro }\end{array}$} \\
\hline Urbana & 20.369 & 0,253 & 0,85 & 0,99 & \\
\hline Rural & 1.771 & 0,022 & 0,07 & 0,56 & \\
\hline
\end{tabular}

Fonte: Censo 2000, IBGE.

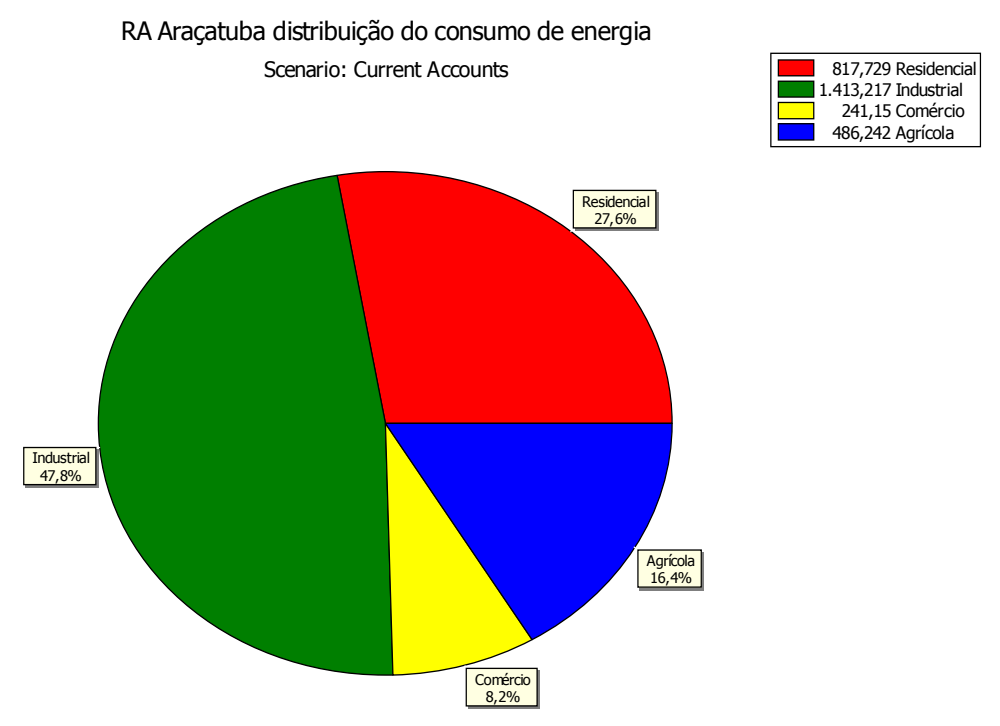

Ilustração 7: distribuição do consumo de energia 
Portanto, o Ano base foi assim constituído:

Setor Residencial

- 99,01 \% das Residências são eletrificadas

- $95 \%$ Estão na área Urbana e 5\% na área Rural

Como pode ser observado na Ilustração 8:
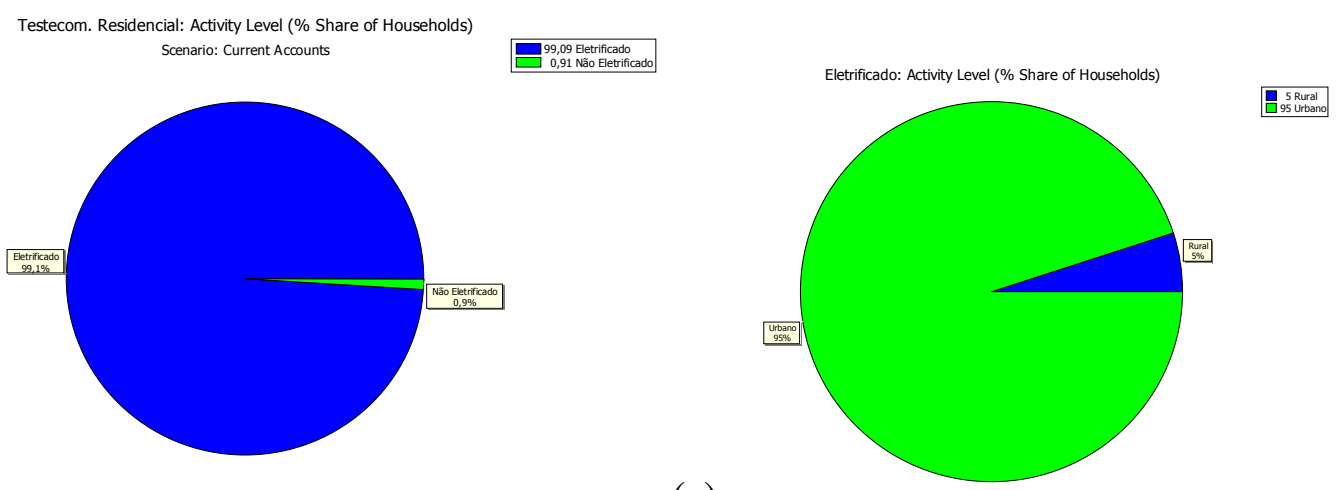

(a)

Ilustração 8: Distribuição de Residências eletrificadas (a) e de Residências Urbanas e Rurais (b)

Fonte: Elaboração Própria

Na área Rural:

- $58 \%$ das residências são de Classe C

- $39 \%$ são de Classe B

- $\quad 3 \%$ são de Classe A

\section{Na área Urbana:}

- $32 \%$ das residências são de Classe C

- $62 \%$ são de Classe B

- $6 \%$ são de Classe A 

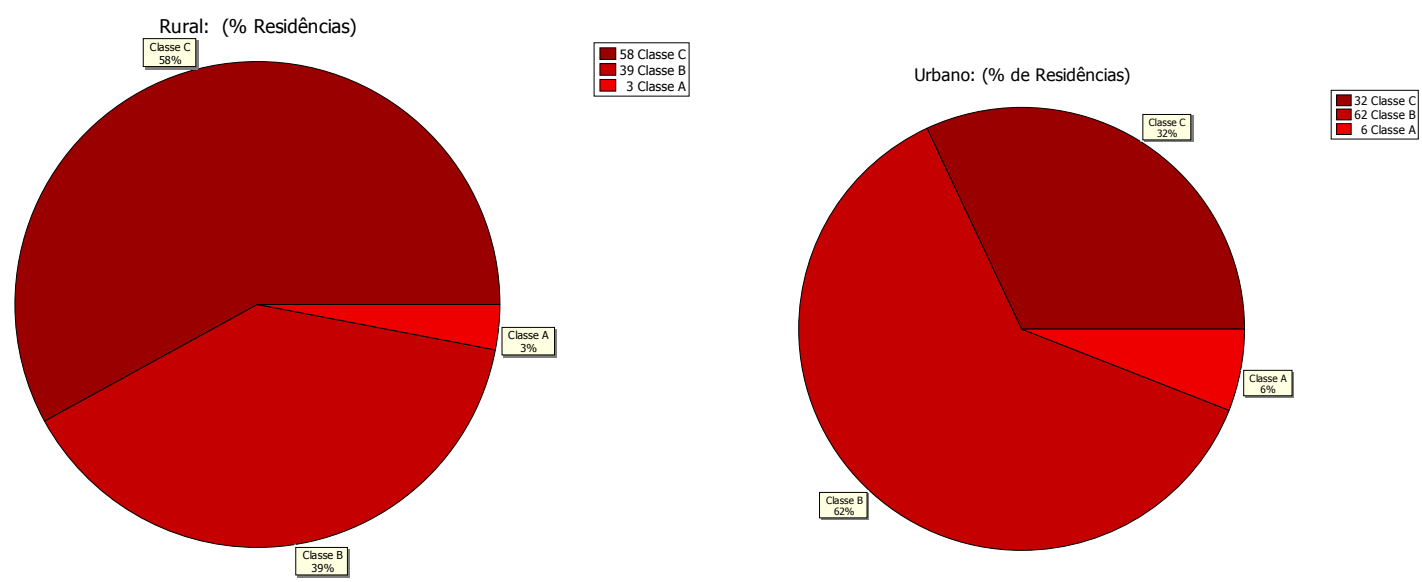

Ilustração 9: Distribuição de Classes entre residências

Fonte: Elaboração Própria

A intensidade energética de Iluminação depende da Classe:

- Em residências da Classe C, lâmpadas incandescentes têm intensidade de 208,534 kWh/ano, lâmpadas de descarga têm intensidade de 39,039 kWh/ano e outros tipos, de $0,7 \mathrm{kWh} / \mathrm{ano}$;

- Nas residências de Classe B, incandescentes são de 273,984 kWh/ano, de descarga tem $68,996 \mathrm{kWh} / \mathrm{ano}$ e outras, de $1,2 \mathrm{kWh} / \mathrm{ano}$;

- Nas de Classe A, incandescentes usam 293,926 kWh/ano, de descarga usam 159,59 $\mathrm{kWh} /$ ano e outras usam $1,8 \mathrm{kWh} / \mathrm{ano}$;

- Para todas as classes, geladeiras novas gastam $600 \mathrm{kWh} / \mathrm{ano}$, antigas gastam 720 $\mathrm{kWh} /$ ano e aparelhos eficientes gastam $444 \mathrm{kWh} / \mathrm{ano}$;

- Freezers novos gastam $402 \mathrm{kWh} / \mathrm{ano}$, antigos gastam $482 \mathrm{kWh} / \mathrm{ano}$ e eficientes gastam 297,5 kWh/ano;

- Aparelhos de ar condicionado novos usam $576 \mathrm{kWh} / \mathrm{ano}$ e antigos usam 691,2 kWh/ano;

- Aspersores usam 45,6 kWh ano;

- Ventiladores usam 57,6 kWh/ano; 
- Aquecedores de água a gás usam $563,4 \mathrm{~m}^{3} / a n o$ de gás natural e aquecedores elétricos gastam 901,44 kWh/ano;

- Fogões a gás natural usam $69,23 \mathrm{~m}^{3} / \mathrm{ano}$, enquanto fogões a GLP usam 47,45 quilogramas/ano, fogões à lenha utilizam 525 quilogramas/ano e fornos elétricos/microondas utilizam $400 \mathrm{kWh} / \mathrm{ano}$;

- Lavadoras de roupa utilizam 75,6 kWh/ano.

\section{Setor Comercial}

Para um melhor aproveitamento dos dados contidos no BEESP 2008 os setores da economia foram divididos em formas de serviços energéticos, e essa distribuição foi feita de acordo com o seu uso elétrico (SEADE, 2008) na RAA, ou seja. A energia elétrica consumida por cada setor é transformada em percentual de participação do setor na energia total do BEESP 2008 e assim dividido em energéticos para cada uso.

- Há 6262 estabelecimentos comerciais em 2008 na região;

- Para força motriz, os estabelecimentos utilizam, em média, $4610 \mathrm{kWh} / a n o$ de eletricidade, $1020 \mathrm{kWh} /$ ano de gás natural, $320 \mathrm{kWh} /$ ano de diesel, $1780 \mathrm{kWh} / \mathrm{ano}$ de GLP e 180 kWh/ano de óleo combustível;

- Foram utilizados em aquecimento, $2760 \mathrm{kWh} /$ ano de eletricidade, $610 \mathrm{kWh} /$ ano de gás natural, 610 kWh/ano de madeira, 190 kWh/ano de diesel, 1070 kWh/ano de GLP e 110 kWh/ano de óleo combustível e 170 kWh/ano de carvão vegetal;

- Para refrigeração, foram utilizados, em média, 10750 kWh/ano de eletricidade;

- Em iluminação, a intensidade energética média é de 13310 kWh/ano de eletricidade;

- O condicionamento ambiental tem intensidade energética de $510 \mathrm{kWh} /$ ano de energia elétrica. 
Setor Industrial

- Há 2906 instalações industriais em 2008 na região;

- Para força motriz, os estabelecimentos utilizam, em média, 87,56 MWh/ano de eletricidade, 62,95 MWh/ano de gás natural, 11,62 MWh/ano de diesel, 7,34 MWh/ano de GLP e 11,60 MWh/ano de óleo combustível;

- Foram utilizados em aquecimento, 25,5 MWh/ano de eletricidade, 18,33 MWh/ano de gás natural, 15,16 MWh/ano de madeira, 3,39 MWh/ano de diesel, 2,14 MWh/ano de GLP e 3,38 MWh/ano de óleo combustível, 2,73 MWh/ano de carvão vegetal e $220 \mathrm{MWh} /$ ano de Bagaço de cana;

- Para refrigeração, foram utilizados, em média, 8,64 MWh/ano de eletricidade;

- Em iluminação, a intensidade energética média é de 4,53 MWh/ano de eletricidade;

- O condicionamento ambiental tem intensidade energética de $710 \mathrm{kWh} / \mathrm{ano}$ de energia elétrica.

Setor Agrícola

- Há 4501 estabelecimentos agrícolas em 2008 na região;

- Para força motriz, os estabelecimentos utilizam, em média, 17,4 MWh/ano de eletricidade, 70,84 MWh/ano de diesel, e 1,39 MWh/ano de óleo combustível;

- Foram utilizados em aquecimento, 5,05 MWh/ano de eletricidade, 0,15 MWh/ano de gás natural, 1,38 MWh/ano de madeira, 20,63 MWh/ano de diesel, e 0,41 MWh/ano de óleo combustível;

- Para refrigeração, foram utilizados, em média 1,72 MWh/ano de eletricidade;

- Em iluminação, a intensidade energética média é de $900 \mathrm{kWh} /$ ano de eletricidade; 
- O condicionamento ambiental tem intensidade energética de $140 \mathrm{kWh} / a n o$ de energia elétrica.

\section{Exportação Energética}

A exportação energética da região refere-se à quantidade de energia produzida inclusa no Sistema Interligado Nacional - SIN - que, para o ano base é quase por completo preenchido pelas grandes usinas hidrelétricas da região, que totalizam $6800 \mathrm{MW}$ de potencia instalada que geram anualmente $59.568 \mathrm{GWh}$.

\subsection{Cenário Tendencial}

O Cenário Tendencial é o alicerce em que se apóia a projeção dos dados de demanda e oferta, seja para basear-se na política e economia vigente, seja para subverter tais dados com a quebra de paradigma. Tal alicerce conta com parâmetros base em setores, sub-setores e serviços energéticos. No caso deste estudo, em que suas tendências não são meras projeções futuras de dados históricos (apesar de, muitas vezes a tendência coincidir com tais projeções, quando se trata de setores ou mercados maduros), mas sim de tendências que o setor apresenta de crescimento, distribuição, evolução de eficiências e perspectivas sociais, econômicas ou de políticas para um determinado setor.

Tal cenário conta com premissas de políticas energéticas que prevêem substituições de tecnologias, modificações em infra-estrutura de base ou de ponta, incentivos a determinados setores para impulsionar o crescimento e alguns outros que veremos a seguir. 


\section{Crescimento dos Setores}

Os determinados setores apresentam um crescimento percentual ano a ano, tanto de número de estabelecimentos quanto de consumo energético individual, que pode ser negativo, dependendo das perspectivas e projeções.

\section{Setor Residencial}

Como pode ser observado na Tabela 12, o crescimento populacional é de 1,5\% a.a. tendendo muito rapidamente a $1,35 \%$ a.a. que é o limite mínimo de crescimento para a Região, segundo o SEADE. Sendo assim, foi adotado como 1,35\% a.a. como crescimento populacional para o setor residencial.

\section{Acesso à Energia}

Devido à políticas governamentais, a tendência é que em cinco anos haja acesso universal à energia elétrica na região.

\section{Distribuição Rural/Urbana}

A distribuição populacional entre zona rural e zona urbana tem leve tendência a um êxodo da cidade para o campo, anulado pelos dados históricos da região que apontam uma leve tendência inversa. Portando foi considerado que a distribuição não se altera. 
RA Araçatuba. Eletrificado: (\% domicílios)

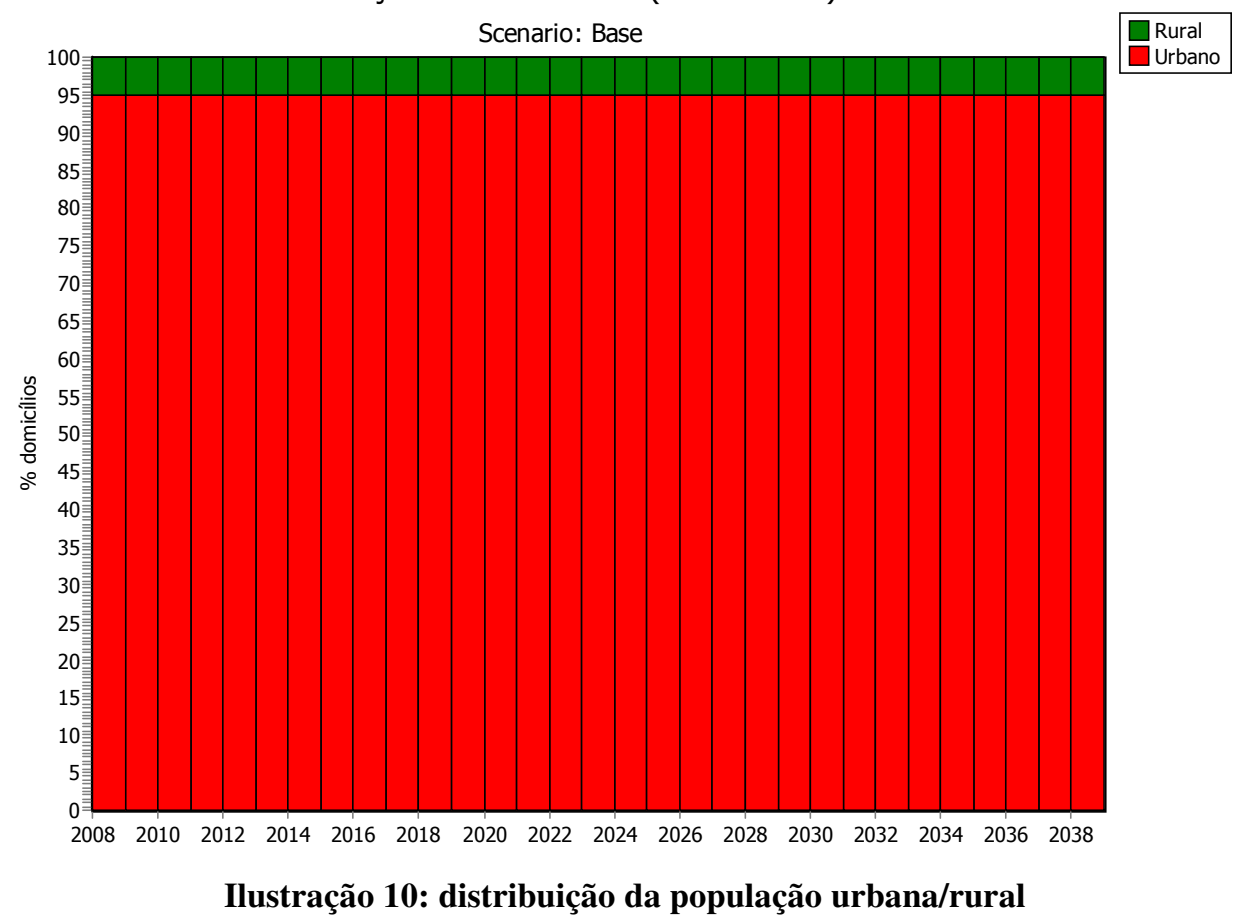

Fonte: elaboração própria com base em dados do SEADE

\section{Distribuição de Renda}

Verificando-se o histórico dos últimos 15 anos ou seguindo projeções socioeconômicas, há uma moderada a forte redistribuição de renda das classes mais baixas da sociedade para as classes médias de renda, e um leve moderado aumento nas classes superiores. Como segue abaixo na Ilustração 11 e na Ilustração 12. 


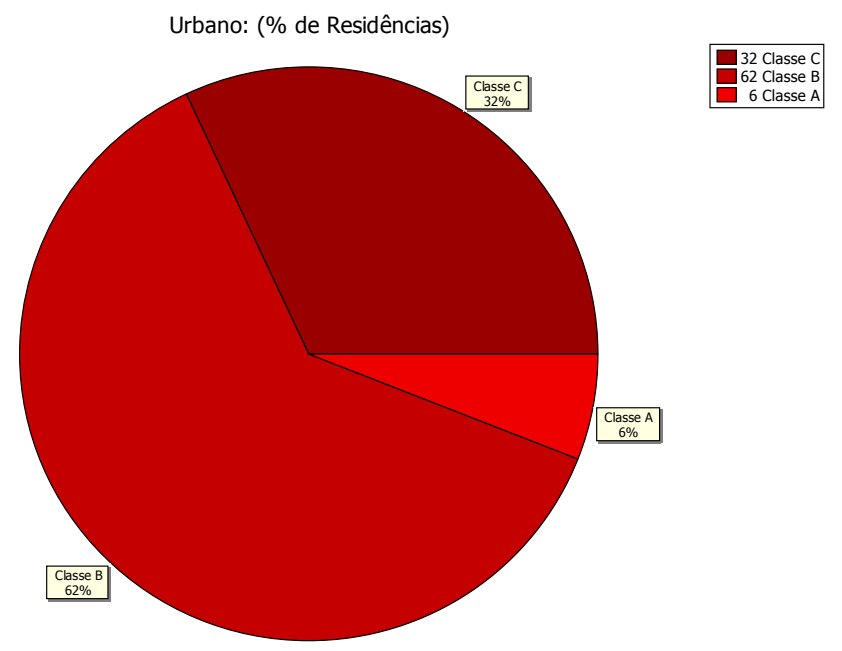

Ilustração 11: Dirstribuição de residências urbanas por classe

Fonte: Elaboração Própria.

- Classe C rural: redução linear de 58\% para 33\% da população;

- Classe A rural: aumento linear de 3\% para 7\% da população;

- Classe C Urbana: redução linear de 32\% para 25\% da população;

- Classe A Urbana: aumento linear de 6 para $10 \%$ da população.
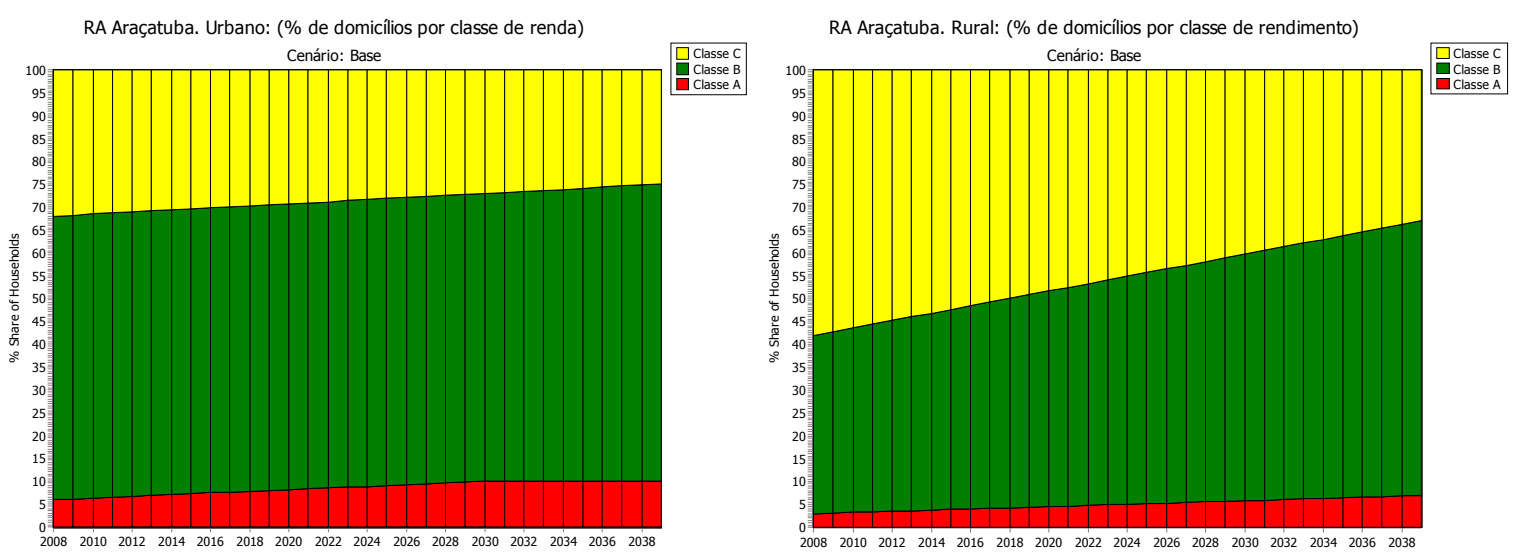

Ilustração 12: Alteração da distribuição de classes de renda ao longo do tempo

Fonte: Elaboração Própria. 


\section{Modificações no perfil de uso de serviços energéticos}

Alguns itens de usos finais foram subdivididos em tecnologias que podem se tornar mais eficientes ou que já o são quando comparadas com outras tecnologias predominantes. Alguns desses itens apresentam uma tendência natural de substituição. No Cenário Tendencial apenas este segundo caso será tratado, deixando os outros casos para cenários sustentáveis ou primorosos.

\section{Iluminação:}

\section{Rural}

Classe C:

- Decréscimo da participação de iluminação incandescente para $20 \%$ do total;

- Decréscimo da participação de cocção por lenha para $1 \%$ e aumento do Gás Natural para 5\%;

Classe B:

- Decréscimo da participação de iluminação incandescente para $20 \%$ do total;

Classe A:

- Decréscimo da participação de iluminação incandescente para 5\% do total;

- Aumento da participação de outras fontes de iluminação para $10 \%$ do total

Como podem ser observados na Ilustração 13. 

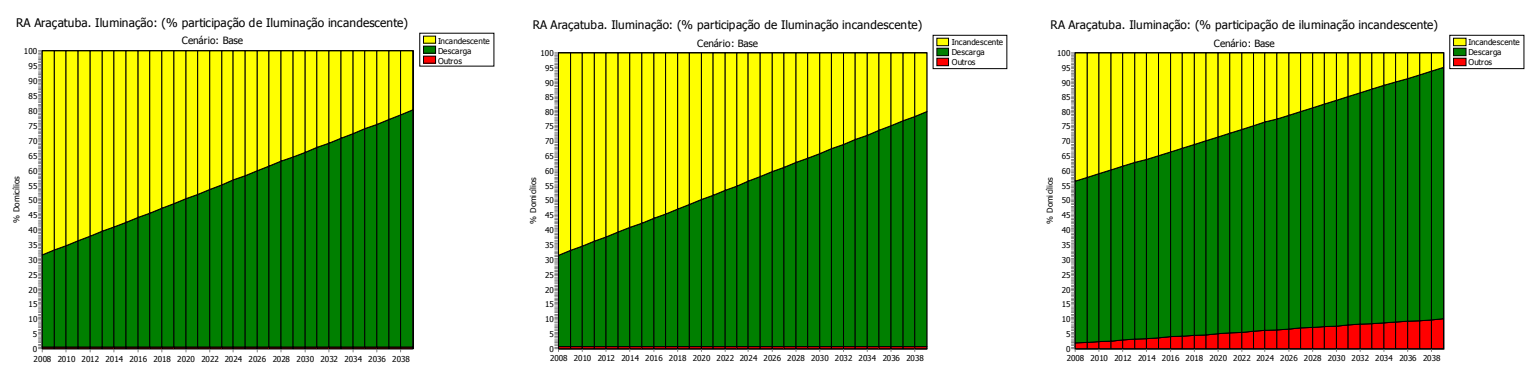

Ilustração 13: Participação das tecnologias de Iluminação ao longo do tempo, Classes C, B e A

Fonte: Elaboração Própria, com base em dados do SINPHA, 2007.

\section{Urbano}

Classe C:

- Decréscimo da participação de iluminação incandescente para 20\% do total;

\section{Classe B:}

Decréscimo da participação de iluminação incandescente para $20 \%$ do total;

Aumento da participação de outras fontes de iluminação para 5\% do total

\section{Classe A}

- Decréscimo da participação de iluminação incandescente para 5\% do total;

- Aumento da participação de outras fontes de iluminação para $10 \%$ do total

- Crescimento do setor Comercial

O Crescimento do setor comercial, para o Cenário Tendencial considerando projeções realizada pela EPE, pelo IBGE, e pelo SEBRAE, é de 3,5\% a.a. 
Deve ser ressaltado que o crescimento geométrico de um setor da economia não corresponde necessariamente ao mesmo crescimento econômico do setor, sendo observado, nos últimos anos que a correlação PIB/Energia consumida deixou de ser 1/1 \% para cerca de 1/0,75\% por ramo de atividade em média.

Crescimento do setor Industrial

O Crescimento do setor Industrial, para o Cenário Tendencial considerando projeções realizada pela EPE, pelo IBGE, e pelo SEBRAE, é de 3\% a.a.

Crescimento do setor Agrícola

O setor agrícola é o ramo de atividade econômica mais forte e mais próspero da região e, em geral, o seu crescimento também está correlacionado com o aumento da oferta de energia devido, em grande parte, ao setor sucroalcooleiro.

O Crescimento do setor Agrícola, para o Cenário Tendencial considerando projeções realizada pela EPE e pelo IBGE, é de 5\% a.a. como mostra a Ilustração 14. 


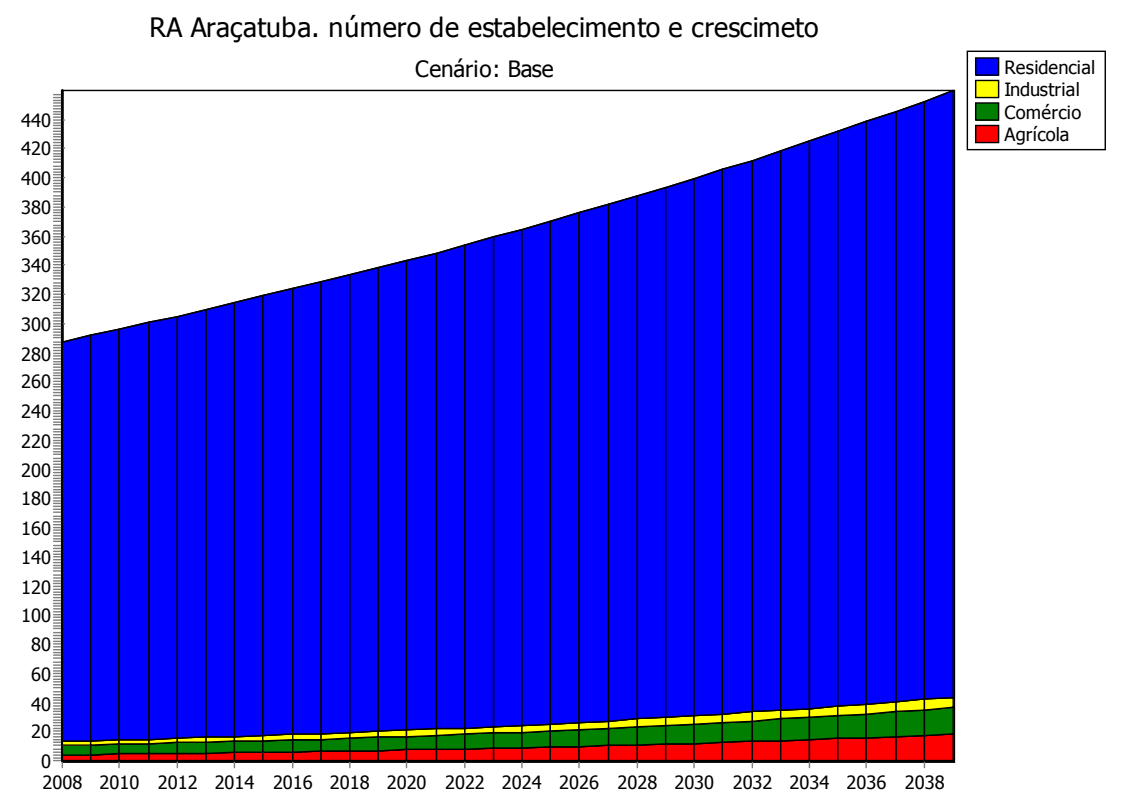

Ilustração 14: número de estabelecimentos/residências e crescimento setorial

Fonte: Elaboração Própria

\section{Geração e Distribuição}

A distribuição de energia elétrica apresenta, em média, 15\% de perdas na transmissão e distribuição.

\subsection{Cenário Sustentável}

As premissas básicas para o cenário sustentável e sua diferenciação para o Cenário Tendencial está, principalmente no aproveitamento dos recursos energéticos tanto de oferta quanto de demanda, priorizando fontes que trarão menores impactos nas dimensões de análise do PIR e melhorias na eficiência do uso final (inclusive no uso das fontes de energia).

O cenário sustentável e também o cenário sustentável-primoroso são cenários que buscam uma análise de quebra de paradigma do cenário tendencial, buscando formas de ilustrar o que é possível alcançar com mudanças estruturais políticas, e sociais. 
As medidas abaixo, quando possível são aplicadas a todos os setores:

Melhorias na distribuição de renda e acesso aos serviços energéticos

Um cenário sustentável deve sê-lo não apenas no aspecto energético ou econômico, mas sustentar todas as variáveis que destes decorrem ou que os afetam. A distribuição de renda, a educação e o incremento no acesso a bens e serviços tanto afetam quanto são afetados pelas políticas energéticas, suas tarifas e oferta, bem como pelo crescimento econômico de determinado setor ou de toda a sociedade.

Para um crescimento sustentável deve se considerar que a distribuição de renda da região apresente significativa melhora:

- Classe C rural: redução linear de $58 \%$ para $20 \%$ da população;

- Classe A rural: aumento linear de $3 \%$ para $10 \%$ da população;

- Classe C Urbana: redução linear de $32 \%$ para $20 \%$ da população;

- Classe A Urbana: aumento linear de 6 para $10 \%$ da população.

Como pode Ser observado na Ilustração 15: 

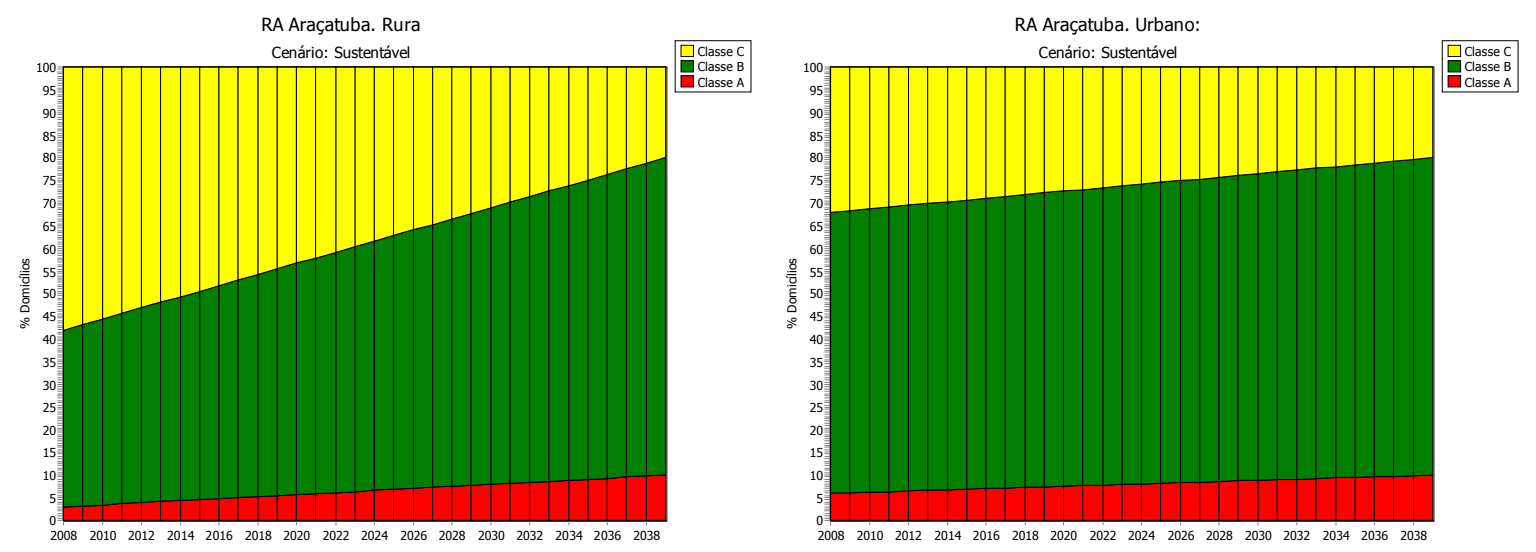

Ilustração 15: Distribuição de Renda ao longo do tempo, por classes de rendimento.

Fonte: Elaboração Própria

\section{Crescimento econômico sustentado}

A sustentabilidade aqui mencionada está longe de ser apenas econômica, mas não se pode diminuir a importância que a economia tem na capacidade de uma sociedade fornecer subsídios para o incremento de outros índices e variáveis que levam à esta sustentabilidade.

Tal crescimento deve dar suporte à quebra de paradigma proposta. Assim temos para a região:

- Crescimento Residencial de $1,35 \%$

- Crescimento industrial de 3\%

- Crescimento comercial de $3,5 \%$

- Crescimento Agrícola de 5\%

- Estabilização do setor Público

\section{Eficiência Energética}

A idéia de sustentabilidade aqui referida está intimamente ligada à eficiência, energética, com que os recursos são aproveitados. Quão maior seja a eficiência do sistema, 
maior a chance de que ele seja sustentável no que tange ao aproveitamento dos recursos, para isso as políticas energéticas devem ser incentivadoras ou, por vezes, austeras quanto ao incremento de eficiência no sistema energético em questão.

Para este cenário foram considerados:

- Aumento da eficiência do setor residencial em $2 \%$ ao ano (decréscimo de $2 \%$ na intensidade energética dos aparelhos);

- Aumento na eficiência do setor comercial em 3\% ao ano;

- Aumento na eficiência do setor industrial em 3,5\% a.a.;

- Aumento na eficiência do setor agrícola em 3,5\% a.a.;

\section{Poder de Compra}

Intimamente ligado aos itens anteriores, o poder de compra traz a possibilidade de que certa parcela da população passe a ter acesso a serviços energéticos antes restritos a classes mais altas, bem como a aparelhos novos que seguem a tendência de diminuição na intensidade energética. Neste cenário foram utilizados parâmetros tais como os apresentados nos próximos itens.

\section{Iluminação}

- Classe C: Desaparecimento de lâmpadas incandescentes e aumento linear da participação de outras formas de iluminação até atingir 55\% em 2039. Cabe aqui mencionar que o percentual não se refere a intensidade energética da tecnologia, mas sim a sua participação no setor, ou seja, a mesma unidade de iluminação pode ser dada por lâmpadas incandescentes, de descarga ou outras, independente da intensidade energética para se atingir tal unidade de iluminação; 
- Classe B: Desaparecimento de lâmpadas incandescentes e aumento linear da participação de outras formas de iluminação até atingir 55\% em 2039;

- Classe A: Desaparecimento de lâmpadas incandescentes e aumento linear da participação de outras formas de iluminação até atingir 70\% em 2039.

\section{Refrigeração}

- Classe C: Aumento linear na participação de aparelhos eficientes até 25\% do total, diminuição dos aparelhos antigos (mais de 5 anos) para 15\% do total;

- Classe B: Aumento linear na participação de aparelhos eficientes até 25\% do total, diminuição dos aparelhos antigos (mais de 5 anos) para 15\% do total;

- Classe A: Aumento linear na participação de aparelhos eficientes até 35\% do total, diminuição dos aparelhos antigos (mais de 5 anos) para 10\% do total;

\section{Aquecimento de Água}

- Classe C: Aumento linear da participação de coletores solares para aquecimento de água para $25 \%$ e erradicação do uso de madeira;

- Classe B: Aumento linear da participação de coletores solares para aquecimento de água para $35 \%$;

- Classe A: Aumento linear da participação de coletores solares para aquecimento de água para $45 \%$;

\section{Políticas Energéticas}

O desenvolvimento sustentável é um conceito que, apesar discutido à exaustão, exige uma quebra de paradigma para que possa ser implantado e observado no longo prazo. E essa ruptura passa por modificar a forma com que se planejam e executam as políticas energéticas 
que vão desenhar o crescimento deste setor e todas as nuances anteriormente mencionadas neste item. Nesse sentido se definem pelo menos políticas evidenciadas e consagradas tais como:

- Fim do uso de iluminação incandescente;

- Incentivo à eficiência energética;

- Utilização de Recursos Energéticos do Lado da Oferta que causem menores impactos (utilizando como parâmetro a classificação pelo PAH).

\section{Geração e Distribuição}

A distribuição de energia elétrica apresenta uma redução linear nas perdas de transmissão e distribuição, partindo de $15 \%$ no ano base até chegar a 6\% em 2020 e se manter estável a partir daí.

\subsection{Cenário Sustentável-primoroso}

O cenário sustentável-primoroso é uma extrapolação das possibilidades do cenário construído. Há uma quebra de paradigmas em diversos ramos e variáveis que compõem as projeções, sejam elas sociais, políticas ou energéticas. Sua construção funda alicerces no cenário sustentável diferindo principalmente em números, mas contando com diferenças estruturais. Otimista

Melhorias na distribuição de renda e acesso aos serviços energéticos

Para o cenário sustentável-primoroso, deve se considerar que a distribuição de renda da região apresente a melhor situação possível em 30 anos, tal como:

- Classe C: redução linear para $10 \%$ da população total; 
- Classe B: aumento linear para $85 \%$ da população;

- Classe A: aumento linear para 5\% da população total;

\section{Eficiência Energética}

- Aumento da eficiência do setor residencial em $5 \%$ ao ano (decréscimo de $2 \%$ na intensidade energética dos aparelhos);

- Aumento na eficiência do setor comercial em $8 \%$ ao ano;

- Aumento na eficiência do setor industrial em 5,5\% a.a.;

- Aumento na eficiência do setor agrícola em 7,5\% a.a.;

\section{Crescimento econômico}

No cenário sustentável-primoroso, deve se buscar os melhores índices de crescimento sem que isso afete o suprimento energético e, com isso o próprio crescimento em si. Nesse sentido assume-o seguinte:

- Crescimento Residencial de $2,1 \%$

- Crescimento industrial de $5 \%$

- Crescimento comercial de $6 \%$

- Crescimento Agrícola de 8\%

- Estabilização do setor Público

\section{Poder de compra}

- Outras formas de iluminação, menos energointensivas, ganham grande espaço no setor residencial: a Classe $\mathrm{C}$ tem um incremento linear até atingir $75 \%$ do total do 
setor, na Classe B o incremento atinge $85 \%$ ao final e para a Classe A o índice é de $90 \%$.

O cenário sustentável-primoroso apresenta:

- Banimento de utilização de lâmpadas incandescentes

- Fortes taxas de eficiência em todos os ramos de atividades

- Melhora dos índices sociais de forma acentuada (distribuição de renda justa e altos índices de desenvolvimento humano, que refletem e realimentam as melhorias em educação).

- Forte crescimento setorial (índices econômicos)

- Crescimento demográfico impulsionado pelo crescimento econômico (obedecendo o item anterior de distribuição de renda e educação).

- Geração e Distribuição

A distribuição de energia elétrica apresenta uma redução linear nas perdas de transmissão e distribuição, partindo de $15 \%$ no ano base até chegar a $10 \%$ em 2020 . A redução das perdas neste cenário se deve à uma necessidade, para um cenário desta natureza, de se aumentar a segurança energética e, como isso ampliar o número de recursos aproveitados (o que acarreta em uma perda maior, apesar dos incentivos à eficiência).

\subsection{Cenário Otimista}

O cenário otimista, ao contrário do cenário sustentável-primoroso , não traz quebras de paradigmas em sua concepção, mas apenas um crescimento dos números do cenário tendenciais, incluindo aqueles que contribuem para o aumento da participação de usos eficientes de energia. 
Crescimento dos setores

- Residencial crescimento de $2,9 \%$ a.a.

- Comercial crescimento de $7 \%$ a.a.

- Agrícola crescimento de 7,5\% a.a.

- Industrial crescimento de 5\% a.a.

- Distribuição de Renda

Tanto na área urbana quanto na área Rural, há uma redistribuição de classes, apresentando :

- Classe C em 10\% do total da população;

- Classe B em 80\%;

- Classe A com $10 \%$

- Poder de Compra

A alteração da distribuição de renda e o conseqüente aumento de renda possibilitam a mudança no perfil de aquisição de eletrodomésticos e uso da energia, apresentado a seguir:

Área Rural, Classe C

\section{Iluminação}

- Incandescente passa a 5\% do total em 2039;

- Outras formas de iluminação serão $10 \%$ do total;

- Lâmpadas de descarga serão 85\% do total, toda apresentando um crescimento linear ao longo do tempo 


\section{Refrigeração}

- Aumento da eficiência em 1,5\% a.a.;

\section{Aquecimento de água}

- Desaparecimento do uso de madeira até 2020

- Aumento do uso de gás natural para 5\% em 2039

\section{Maquina de lavar}

- Aumento da eficiência em 1,5\%

Área Rural, Classe B

\section{Iluminação}

- Incandescente passa a $2 \%$ do total em 2039;

- Outras formas de iluminação serão $20 \%$ do total;

- Lâmpadas de descarga serão $78 \%$ do total, toda apresentando um crescimento linear ao longo do tempo

\section{Refrigeração}

- Aumento da eficiência em 1,5\% a.a. para geladeiras e freezers novos e antigos e $2 \%$ para aparelhos já eficientes;

- Presença de ao menos uma geladeira em todas as residências e de freezers em $35 \%$ das residências

- $60 \%$ dos aparelhos, tanto freezers quanto geladeiras, serão aparelhos novos e outros 25\% serão aparelhos eficientes; 


\section{Condicionamento ambiental}

- $35 \%$ das residências contarão com algum tipo de refrigeração

- Sendo $85 \%$ de aparelhos de ar condicionado

- Desses aparelhos, $70 \%$ serão novos

- Aumento da eficiência de todos os aparelhos em 1,5\% a.a.

\section{Aquecimento de água}

- Aumento do uso de gás natural para 5\% em 2039

- Aumento do uso de energia solar para aquecimento para $15 \%$ do total

\section{Maquina de lavar}

- Aumento da eficiência em $1,5 \%$

Área Rural, Classe A

\section{Iluminação}

- Incandescente passa a 0\% do total em 2039;

- Outras formas de iluminação serão $35 \%$ do total;

- Lâmpadas de descarga serão $65 \%$ do total, toda apresentando um crescimento linear ao longo do tempo

\section{Refrigeração}

- Aumento da eficiência em 1,5\% a.a. para geladeiras e freezers novos e antigos e 2\% para aparelhos já eficientes; 
- Presença de ao menos uma geladeira em todas as residências e de freezers em $85 \%$ das residências

- $35 \%$ dos aparelhos, tanto freezers quanto geladeiras, serão aparelhos novos e outros 50\% serão aparelhos eficientes;

\section{Condicionamento ambiental}

- $85 \%$ das residências contarão com algum tipo de refigeração

- Sendo $80 \%$ de aparelhos de ar condicionado

- Desses aparelhos, $70 \%$ serão novos

- Aumento da eficiência de todos os aparelhos em 1,5\% a.a.

\section{Aquecimento de água}

- Aumento do uso de gás natural para 5\% em 2039

- Aumento do uso de energia solar para aquecimento para $25 \%$ do total

\section{Maquina de lavar}

- Aumento da eficiência em $1,5 \%$

Área Urbana, Classe C

\section{Iluminação}

- Incandescente passa a 5\% do total em 2039;

- Outras formas de iluminação serão $10 \%$ do total;

- Lâmpadas de descarga serão 85\% do total, toda apresentando um crescimento linear ao longo do tempo 


\section{Refrigeração}

- Aumento da eficiência em 1,5\% a.a.;

\section{Aquecimento de água}

- Desaparecimento do uso de madeira até 2020

- Aumento do uso de gás natural para $10 \%$ em 2039

\section{Maquina de lavar}

- Aumento da eficiência em 1,5\%

Área Urbana, Classe B

\section{Iluminação}

- Incandescente passa a $2 \%$ do total em 2039;

- Outras formas de iluminação serão $20 \%$ do total;

- Lâmpadas de descarga serão $78 \%$ do total, toda apresentando um crescimento linear ao longo do tempo

\section{Refrigeração}

- Aumento da eficiência em 1,5\% a.a. para geladeiras e freezers novos e antigos e $2 \%$ para aparelhos já eficientes;

- Presença de ao menos uma geladeira em todas as residências e de freezers em $35 \%$ das residências

- $60 \%$ dos aparelhos, tanto freezers quanto geladeiras, serão aparelhos novos e outros $25 \%$ serão aparelhos eficientes; 


\section{Condicionamento ambiental}

- $35 \%$ das residências contarão com algum tipo de refigeração

- Sendo $85 \%$ de aparelhos de ar condicionado

- Desses aparelhos, $70 \%$ serão novos

- Aumento da eficiência de todos os aparelhos em 1,5\% a.a.

\section{Aquecimento de água}

- Aumento do uso de gás natural para 5\% em 2039

- Aumento do uso de energia solar para aquecimento para $15 \%$ do total

\section{Maquina de lavar}

- Aumento da eficiência em $1,5 \%$

Área Urbana, Classe A

\section{Iluminação}

- Incandescente passa a $0 \%$ do total em 2039;

- Outras formas de iluminação serão $35 \%$ do total;

- Lâmpadas de descarga serão $65 \%$ do total, toda apresentando um crescimento linear ao longo do tempo

\section{Refrigeração}

- Aumento da eficiência em 1,5\% a.a. para geladeiras e freezers novos e antigos e 2\% para aparelhos já eficientes; 
- Presença de ao menos uma geladeira em todas as residências e de freezers em $85 \%$ das residências

- $35 \%$ dos aparelhos, tanto freezers quanto geladeiras, serão aparelhos novos e outros 50\% serão aparelhos eficientes;

\section{Condicionamento ambiental}

- $85 \%$ das residências contarão com algum tipo de refrigeração

- Sendo $80 \%$ de aparelhos de ar condicionado

- Desses aparelhos, $70 \%$ serão novos

- Aumento da eficiência de todos os aparelhos em 1,5\% a.a.

\section{Aquecimento de água}

- Aumento do uso de gás natural para 5\% em 2039

- Aumento do uso de energia solar para aquecimento para $25 \%$ do total

\section{Maquina de lavar}

- Aumento da eficiência em 1,5\%

Aumento da eficiência

Para cada um dos setores há um acréscimo de eficiência nos usos finais de:

- Industrial: $2 \%$ a.a.

- Comercial: $1,5 \%$ a.a.

- Agrícola: $1,5 \%$ a.a 


\subsection{Previsão de Demanda}

\subsubsection{Previsão de Demanda para o Cenário Tendencial}

A Tabela 16 apresenta a previsão de consumo de energia para o setor residencial e a

Tabela 17 discrimina os resultados por energético para o cenário Tendencial.

Tabela 16: Previsão de consumo de energia no setor residencial (em mil MWh/ano)

\begin{tabular}{|l|r|r|r|r|r|r|r|r|r|r|r|}
\hline Ano & 2008 & \multicolumn{1}{|c|}{2009} & 2010 & 2011 & 2012 & 2018 & 2022 & 2026 & 2030 & 2035 & 2039 \\
\hline Eletrificado $(\mathrm{MWh})$ & 814,6 & 828,5 & 842,4 & 856,3 & 870,2 & 944,2 & 990,4 & $1.034,2$ & $1.075,1$ & $1.122,8$ & $1.155,9$ \\
\hline Não Eletrificado & 2,6 & 2,1 & 1,6 & 1,1 & 0,5 & 0,0 & 0,0 & 0,0 & 0,0 & 0,0 & 0,0 \\
\hline Total & $\mathbf{8 1 7 , 1}$ & $\mathbf{8 3 0 , 6}$ & $\mathbf{8 4 4 , 0}$ & $\mathbf{8 5 7 , 3}$ & $\mathbf{8 7 0 , 7}$ & $\mathbf{9 4 4 , 2}$ & $\mathbf{9 9 0 , 4}$ & $\mathbf{1 . 0 3 4 , 2}$ & $\mathbf{1 . 0 7 5 , \mathbf { 1 }}$ & $\mathbf{1 . 1 2 2 , 8}$ & $\mathbf{1 . 1 5 5 , 9}$ \\
\hline
\end{tabular}

Fonte: Elaboração Própria

Tabela 17: Previsão de Consumo de energia do setor residencial por energético (em mil MWh/ano)

\begin{tabular}{|c|c|c|c|c|c|c|c|c|c|c|c|}
\hline & 2008 & 2009 & 2010 & 2011 & 2012 & 2018 & 2022 & 2026 & 2030 & 2035 & 2039 \\
\hline Lenha & 25,1 & 25,3 & 25,6 & 25,8 & 26,0 & 27,7 & 28,9 & 30,2 & 31,6 & 33,4 & 35,0 \\
\hline Gás Natural & 42,1 & 42,6 & 43,0 & 43,5 & 44,0 & 46,4 & 48,0 & 49,6 & 51,3 & 53,1 & 54,6 \\
\hline GLP & 165,5 & 167,6 & 169,8 & 171,9 & 174,1 & 188,4 & 198,7 & 209,5 & 220,9 & 236,3 & 249,4 \\
\hline Querosene & 0,2 & 0,2 & 0,1 & 0,1 & 0,0 & 0,0 & 0,0 & 0,0 & 0,0 & 0,0 & 0,0 \\
\hline Eletricidade & 584,7 & 597,2 & 609,9 & 622,8 & 635,8 & 711,2 & 763,3 & 817,6 & 873,9 & 949,1 & $1.011,7$ \\
\hline Total & 817,7 & 832,9 & 848,4 & 864,1 & 880,0 & 973,7 & $1.038,9$ & $1.106,9$ & $1.177,7$ & $1.271,9$ & $1.350,6$ \\
\hline
\end{tabular}

Fonte: Elaboração Própria

A Tabela 18 apresenta a previsão de consumo de energia por setor.

Tabela 18: Previsão do consumo de energia por setor (mil MWh/ano)

\begin{tabular}{|c|c|c|c|c|c|c|c|c|c|c|c|}
\hline & 2008 & 2009 & 2010 & 2011 & 2012 & 2018 & 2022 & 2026 & 2030 & 2035 & 2039 \\
\hline Residencial & 817,7 & 833,0 & 848,5 & 864,1 & 880,0 & 973,7 & $1.038,9$ & $1.106,9$ & $1.177,8$ & $1.271,9$ & $1.350,7$ \\
\hline Industrial & $1.413,2$ & $1.455,6$ & $1.499,3$ & $1.544,3$ & $1.590,6$ & $1.899,2$ & $2.137,6$ & $2.405,9$ & $2.707,9$ & $3.139,2$ & $3.533,2$ \\
\hline Comércio & 241,1 & 249,6 & 258,3 & 267,4 & 276,7 & 340,2 & 390,3 & 447,9 & 514,0 & 610,5 & 700,5 \\
\hline Publico & 117,8 & 117,8 & 117,8 & 117,8 & 117,8 & 117,8 & 117,8 & 117,8 & 117,8 & 117,8 & 117,8 \\
\hline Agrícola & 486,2 & 510,6 & 536,1 & 562,9 & 591,0 & 792,0 & 962,7 & $1.170,2$ & $1.422,4$ & $1.815,4$ & $2.206,6$ \\
\hline Total & $3.076,1$ & $3.166,5$ & $3.259,9$ & $3.356,4$ & $3.456,1$ & $4.123,0$ & $4.647,4$ & $5.248,7$ & $5.939,8$ & $6.954,7$ & $7.908,7$ \\
\hline
\end{tabular}

Fonte: Elaboração Própria

A Tabela 19 e a Ilustração 16 mostram a previsão de consumo de energia elétrica para todos os setores no horizonte de planejamento. 
Tabela 19: Previsão de consumo de energia elétrica por setor (mil GWh)

\begin{tabular}{|c|c|c|c|c|c|c|c|c|c|c|c|c|}
\hline & 2008 & 2009 & 2010 & 2011 & 2012 & 2013 & 2014 & 2019 & 2024 & 2029 & 2034 & 2039 \\
\hline Residencial & 0,585 & 0,597 & 0,610 & 0,623 & 0,636 & 0,649 & 0,661 & 0,724 & 0,790 & 0,860 & 0,934 & 1,012 \\
\hline Industrial & 0,369 & 0,380 & 0,391 & 0,403 & 0,415 & 0,428 & 0,441 & 0,511 & 0,592 & 0,686 & 0,796 & 0,922 \\
\hline Publico & 0,101 & 0,101 & 0,101 & 0,101 & 0,101 & 0,101 & 0,101 & 0,101 & 0,101 & 0,101 & 0,101 & 0,101 \\
\hline Comércio & 0,200 & 0,207 & 0,214 & 0,222 & 0,230 & 0,238 & 0,246 & 0,292 & 0,347 & 0,412 & 0,489 & 0,581 \\
\hline Agrícola & 0,102 & 0,107 & 0,113 & 0,118 & 0,124 & 0,130 & 0,137 & 0,175 & 0,223 & 0,285 & 0,363 & 0,464 \\
\hline Exportação & 60,0 & 60,0 & 60,0 & 60,0 & 60,0 & 60,0 & 60,0 & 60,0 & 60,0 & 60,0 & 60,0 & 60,0 \\
\hline Total & 61,4 & 61,4 & 61,4 & 61,5 & 61,5 & 61,5 & 61,6 & 61,8 & 62,1 & 62,3 & 62,7 & 63,1 \\
\hline
\end{tabular}

Fonte: Elaboração Própria

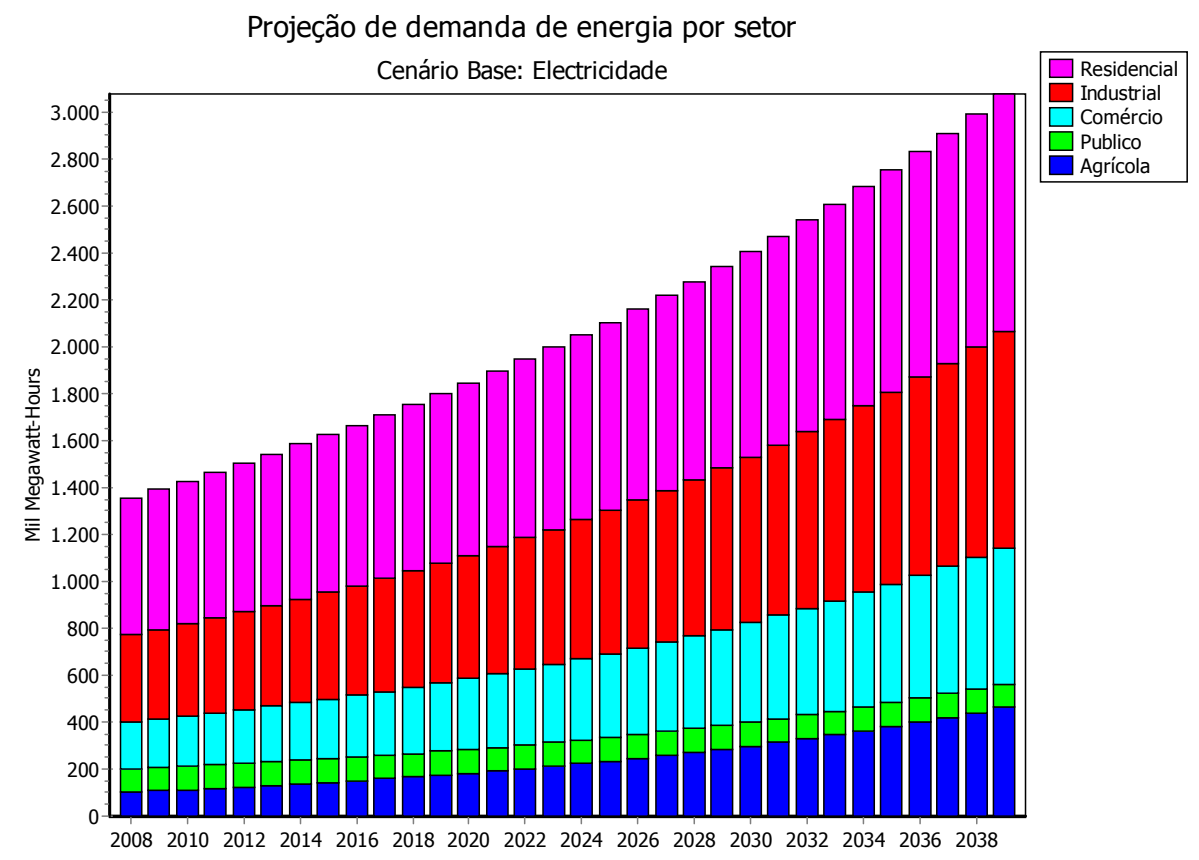

Ilustração 16: demanda de energia elétrica

Fonte: Elaboração Própria.

A Ilustração 17 a e b apresenta o consumo de energia elétrica no setor residencial por classes 

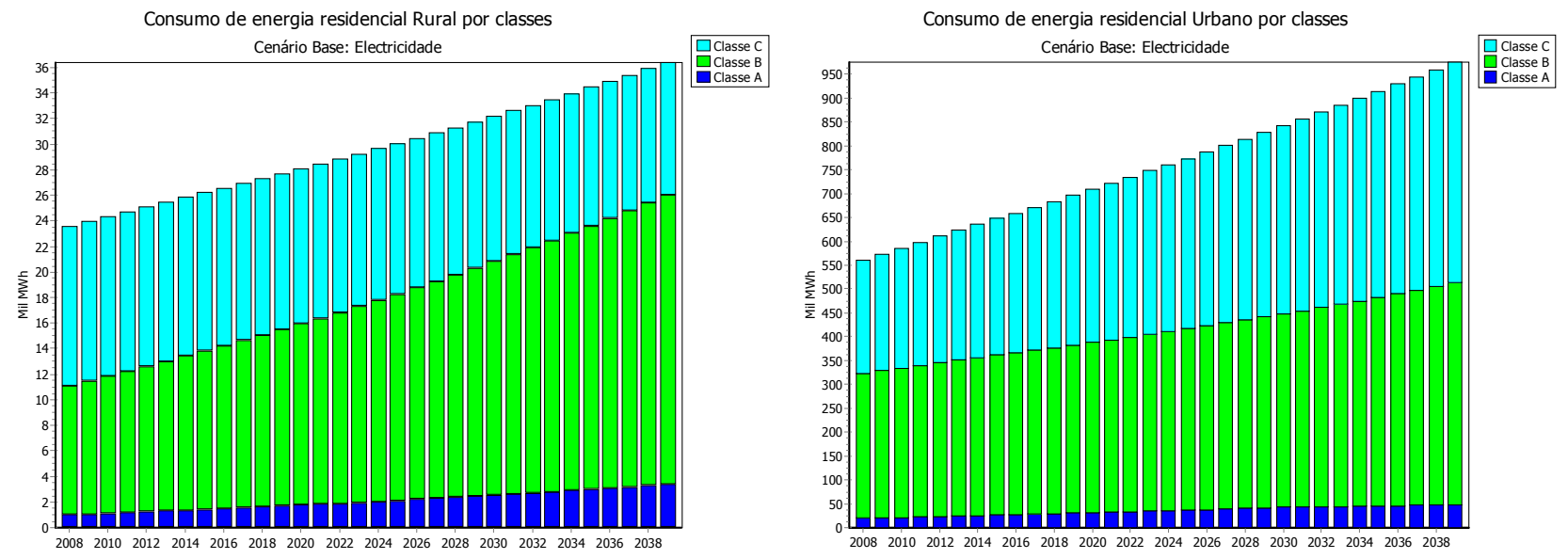

Ilustração 17 a e b: Consumo de energia elétrica por classes - Setor residencial

Fonte: Elaboração Própria.

\subsubsection{Previsão de Demanda para o Cenário Sustentável}

A Ilustração 18 e a Tabela 20 apresentam as projeções de consumo de energia total por setor

Tabela 20: Previsão de consumo por setor: Cenário Sustentável (mil MWh)

\begin{tabular}{|c|c|c|c|c|c|c|c|c|c|c|c|}
\hline Mil MWh & 2008 & 2009 & 2010 & 2011 & 2012 & 2018 & 2022 & 2026 & 2030 & 2035 & 2039 \\
\hline Residencial & 817,7 & 820,0 & 822,3 & 824,5 & 826,6 & 833,2 & 835,4 & 836,0 & 835,0 & 830,5 & 824,3 \\
\hline Industrial & $1.413,2$ & $1.404,7$ & $1.396,2$ & $1.387,7$ & $1.379,3$ & $1.330,0$ & $1.298,1$ & $1.267,0$ & $1.236,6$ & $1.199,6$ & $1.170,9$ \\
\hline Comércio & 241,1 & 242,1 & 243,1 & 244,0 & 245,0 & 250,8 & 254,8 & 258,9 & 263,0 & 268,2 & 272,5 \\
\hline Publico & 117,8 & 117,8 & 117,8 & 117,8 & 117,8 & 117,8 & 117,8 & 117,8 & 117,8 & 117,8 & 117,8 \\
\hline Agrícola & 486,2 & 492,7 & 499,2 & 505,8 & 512,5 & 554,6 & 584,6 & 616,2 & 649,6 & 693,7 & 731,3 \\
\hline Total & $3.076,1$ & $3.077,3$ & $3.078,5$ & $3.079,8$ & $3.081,2$ & $3.086,5$ & $3.090,7$ & $3.095,9$ & $3.101,9$ & $3.109,9$ & $3.116,7$ \\
\hline
\end{tabular}

Fonte: Elaboração Própria 


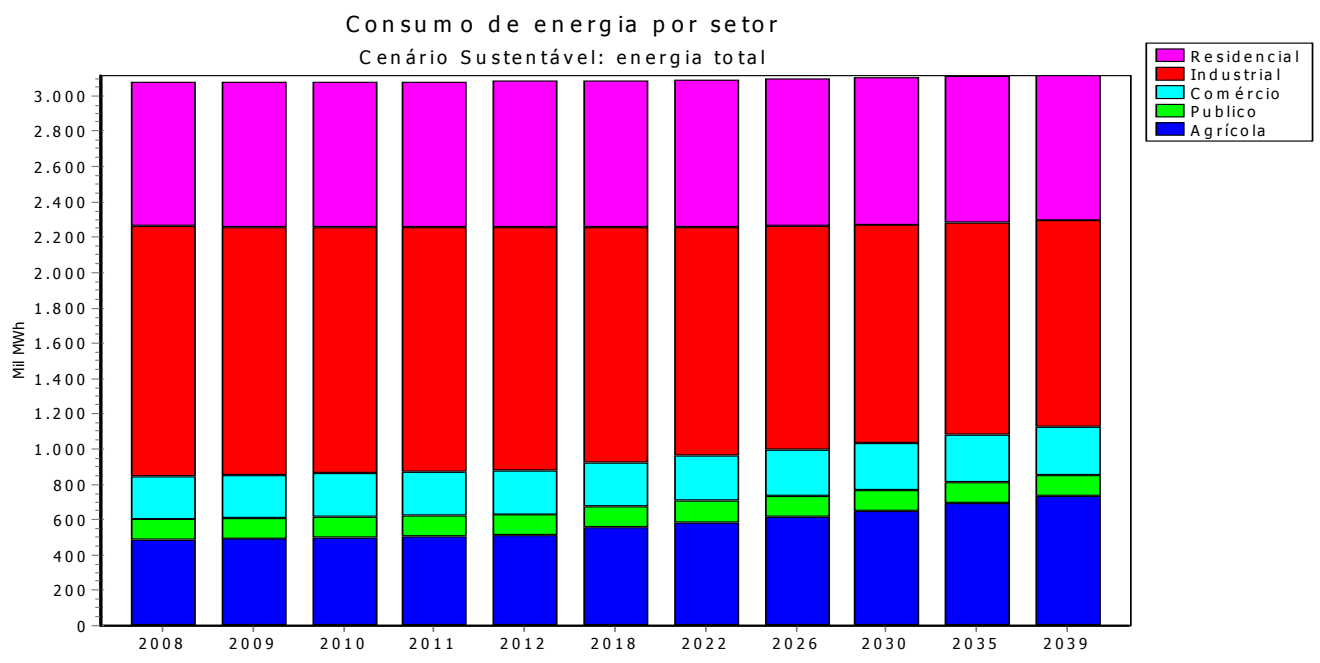

Ilustração 18: Consumo de energia por setor

Fonte: Elaboração própria.

A Tabela 21 apresenta a previsão de consumo de energia elétrica por setor para o cenário Sustentável.

Tabela 21: Consumo de energia elétrica por setor (mil GWh/ano)

\begin{tabular}{|c|c|c|c|c|c|c|c|c|c|c|c|c|}
\hline & 2008 & 2009 & 2010 & 2011 & 2012 & 2013 & 2014 & 2019 & 2024 & 2029 & 2034 & 2039 \\
\hline Residencial & 0,585 & 0,585 & 0,586 & 0,587 & 0,587 & 0,587 & 0,587 & 0,582 & 0,575 & 0,566 & 0,554 & 0,538 \\
\hline Industrial & 0,369 & 0,367 & 0,364 & 0,362 & 0,360 & 0,358 & 0,356 & 0,345 & 0,335 & 0,325 & 0,315 & 0,306 \\
\hline Publico & 0,101 & 0,101 & 0,101 & 0,101 & 0,101 & 0,101 & 0,101 & 0,101 & 0,101 & 0,101 & 0,101 & 0,101 \\
\hline Comércio & 0,200 & 0,201 & 0,202 & 0,202 & 0,203 & 0,204 & 0,205 & 0,209 & 0,213 & 0,217 & 0,222 & 0,226 \\
\hline Agrícola & 0,102 & 0,104 & 0,105 & 0,106 & 0,108 & 0,109 & 0,111 & 0,118 & 0,126 & 0,135 & 0,144 & 0,154 \\
\hline Exportação & 60,0 & 60,6 & 61,2 & 61,8 & 62,4 & 63,1 & 63,7 & 66,9 & 70,4 & 73,9 & 77,7 & 81,7 \\
\hline Total & 61,4 & 62,0 & 62,6 & 63,2 & 63,8 & 64,4 & 65,0 & 68,3 & 71,7 & 75,3 & 79,1 & 83,0 \\
\hline
\end{tabular}

Fonte: Elaboração própria 
3.9.3 Previsão de Demanda para o Cenário Sustentável-Primoroso

A Tabela 22 apresenta a previsão para o consumo total de energia para a RAA.

Tabela 22: Consumo total de energia por setor

\begin{tabular}{|c|c|c|c|c|c|c|c|c|c|c|c|}
\hline $\begin{array}{c}\text { Ano/ } \\
\text { mil MWh }\end{array}$ & 2008 & 2009 & 2010 & 2011 & 2012 & 2018 & 2022 & 2026 & 2030 & 2035 & 2039 \\
\hline Residencial & 817,7 & 828,6 & 834,7 & 840,6 & 846,3 & 869,6 & 848,9 & 798,2 & 746,1 & 679,5 & 625,6 \\
\hline Industrial & $1.413,2$ & $1.402,3$ & $1.391,4$ & $1.380,6$ & $1.369,9$ & $1.307,4$ & $1.267,4$ & $1.228,5$ & $1.190,9$ & $1.145,5$ & $1.110,4$ \\
\hline Comércio & 241,1 & 235,2 & 229,3 & 223,6 & 218,1 & 187,6 & 169,7 & 153,5 & 138,8 & 122,4 & 110,7 \\
\hline Publico & 117,8 & 117,8 & 117,8 & 117,8 & 117,8 & 117,8 & 117,8 & 117,8 & 117,8 & 117,8 & 117,8 \\
\hline Agrícola & 486,2 & 485,8 & 485,3 & 484,8 & 484,3 & 481,4 & 479,5 & 477,6 & 475,7 & 473,3 & 471,4 \\
\hline Total & $\mathbf{3 . 0 7 6 , 1}$ & $\mathbf{3 . 0 6 9 , 6}$ & $\mathbf{3 . 0 5 8 , 5}$ & $\mathbf{3 . 0 4 7 , 4}$ & $\mathbf{3 . 0 3 6 , 4}$ & $\mathbf{2 . 9 6 3 , 8}$ & $\mathbf{2 . 8 8 3 , 2}$ & $\mathbf{2 . 7 7 5 , 5}$ & $\mathbf{2 . 6 6 9 , 2}$ & $\mathbf{2 . 5 3 8 , 5}$ & $\mathbf{2 . 4 3 5 , 9}$ \\
\hline
\end{tabular}

Fonte: Elaboração própria
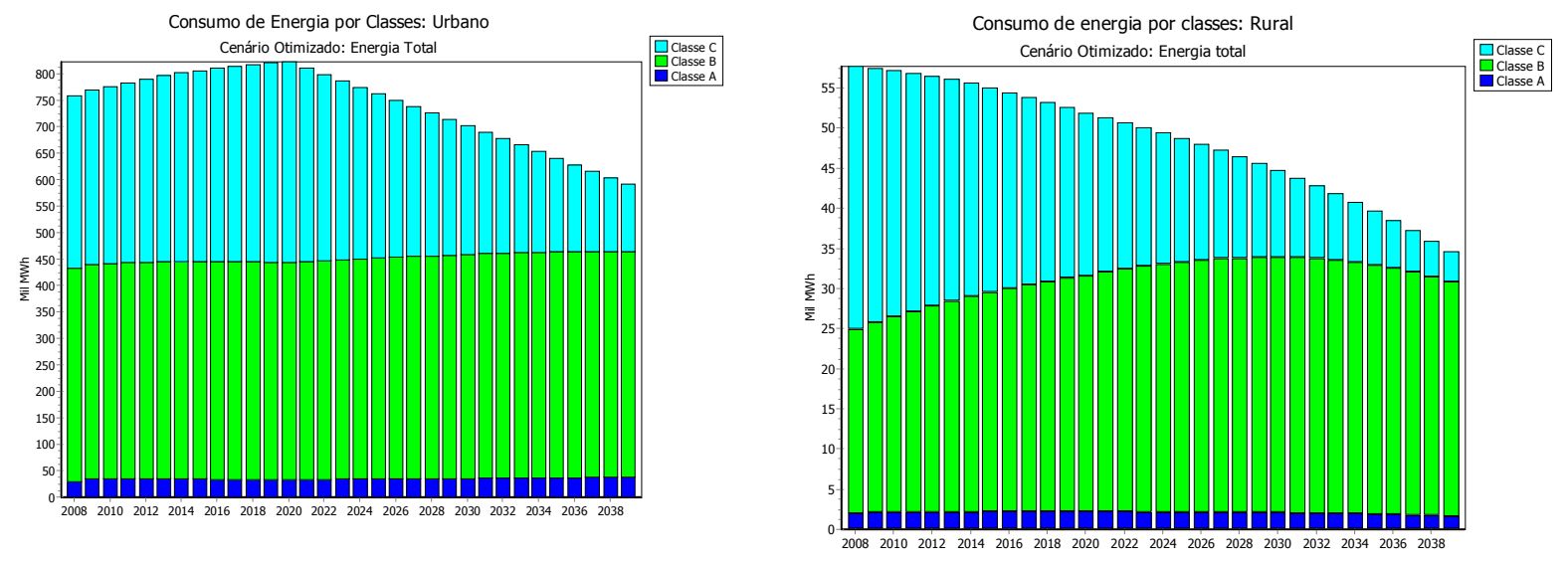

Ilustração 19: Consumo de energia por classe de renda: cenário sustentável-primoroso

Fonte: Elaboração própria 

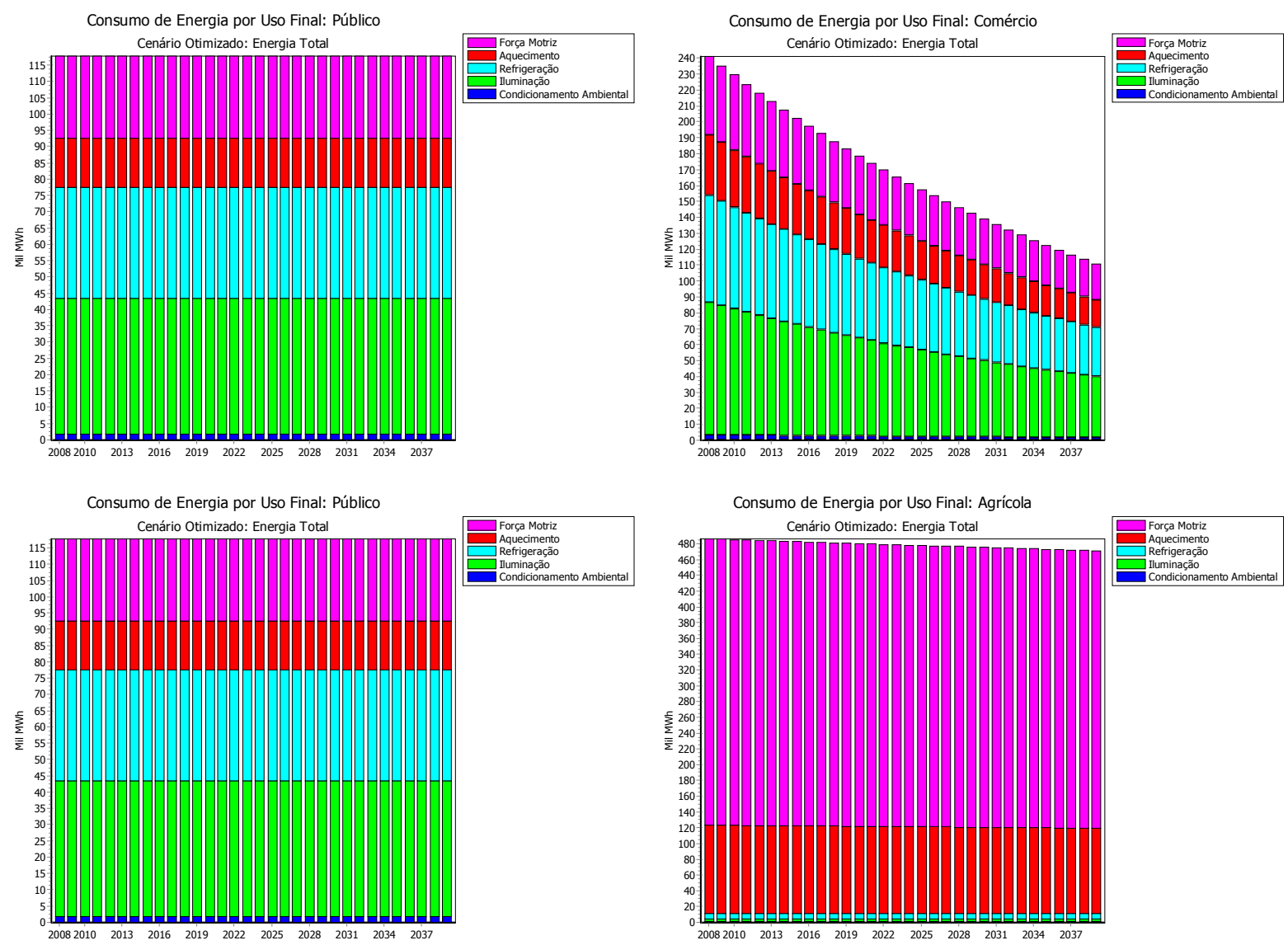

Ilustração 20: usos finais por setor

Fonte: Elaboração Própria

A Tabela 23 apresenta a previsão de consumo de energia elétrica por setor para o cenário Sustentável-Primoroso

Tabela 23: Consumo de energia elétrica por setor (mil GWh/ano)

\begin{tabular}{|c|c|c|c|c|c|c|c|c|c|c|c|c|}
\hline & 2008 & 2009 & 2010 & 2011 & 2012 & 2013 & 2014 & 2019 & 2024 & 2029 & 2034 & 2039 \\
\hline Residencial & 0,585 & 0,593 & 0,596 & 0,598 & 0,601 & 0,604 & 0,605 & 0,604 & 0,539 & 0,457 & 0,373 & 0,288 \\
\hline Industrial & 0,369 & 0,366 & 0,363 & 0,360 & 0,358 & 0,355 & 0,352 & 0,339 & 0,326 & 0,313 & 0,301 & 0,290 \\
\hline Publico & 0,101 & 0,101 & 0,101 & 0,101 & 0,101 & 0,101 & 0,101 & 0,101 & 0,101 & 0,101 & 0,101 & 0,101 \\
\hline Comércio & 0,200 & 0,195 & 0,190 & 0,186 & 0,181 & 0,176 & 0,172 & 0,152 & 0,134 & 0,118 & 0,104 & 0,092 \\
\hline Agrícola & 0,102 & 0,102 & 0,102 & 0,102 & 0,102 & 0,102 & 0,102 & 0,101 & 0,101 & 0,100 & 0,100 & 0,099 \\
\hline Exportação & 60,0 & 61,2 & 62,4 & 63,7 & 64,9 & 66,2 & 67,6 & 74,6 & 82,4 & 90,9 & 100,4 & 110,9 \\
\hline Total & 61,4 & 62,6 & 63,8 & 65,0 & 66,3 & 67,6 & 68,9 & 75,9 & 83,6 & 92,0 & 101,4 & 111,7 \\
\hline
\end{tabular}

Fonte: Elaboração Própria 


\subsubsection{Previsão de Demanda para o Cenário Otimista}

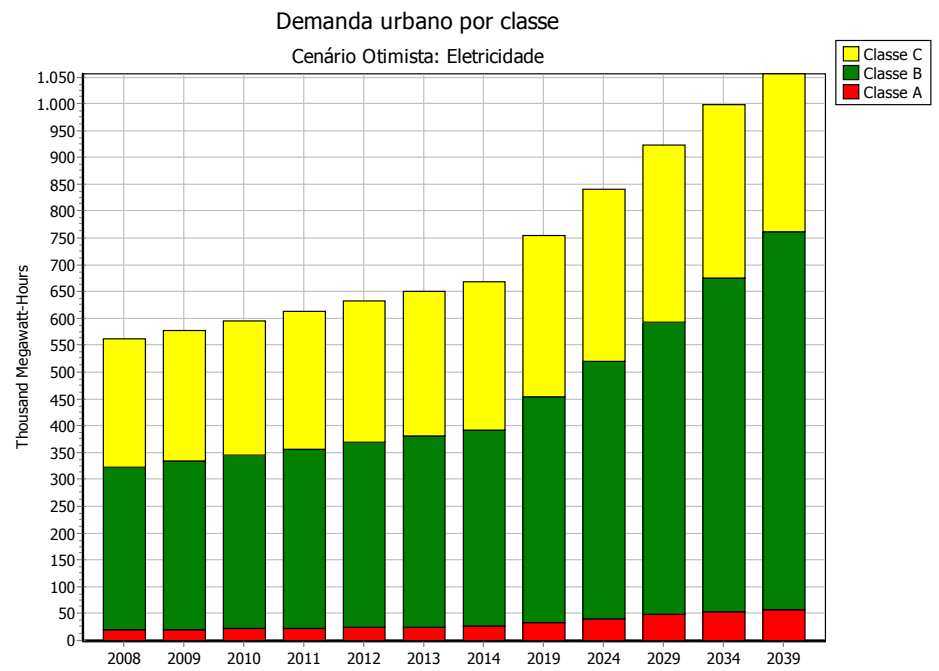

Ilustração 21: gráfico da distribuição de consumo de energia elétrica por classes na área urbana

Fonte: Elaboração Própria

A Tabela 23 apresenta a previsão de consumo de energia elétrica por setor para o cenário Sustentável-Primoroso

Tabela 24: Previsão de Consumo de energia elétrica para o cenário Otimista (mil GWh ano)

\begin{tabular}{|c|c|c|c|c|c|c|c|c|c|c|c|c|}
\cline { 2 - 13 } \multicolumn{1}{c|}{} & 2008 & 2009 & 2010 & 2011 & 2012 & 2013 & 2014 & 2019 & 2024 & 2029 & 2034 & 2039 \\
\hline Residencial & 0,585 & 0,602 & 0,620 & 0,638 & 0,657 & 0,675 & 0,693 & 0,781 & 0,869 & 0,951 & 1,025 & 1,082 \\
\hline Industrial & 0,369 & 0,378 & 0,387 & 0,396 & 0,405 & 0,415 & 0,425 & 0,478 & 0,537 & 0,604 & 0,679 & 0,764 \\
\hline Publico & 0,101 & 0,101 & 0,101 & 0,101 & 0,101 & 0,101 & 0,101 & 0,101 & 0,101 & 0,101 & 0,101 & 0,101 \\
\hline Comércio & 0,200 & 0,210 & 0,220 & 0,231 & 0,242 & 0,254 & 0,266 & 0,337 & 0,427 & 0,542 & 0,687 & 0,871 \\
\hline Agrícola & 0,102 & 0,108 & 0,115 & 0,122 & 0,129 & 0,137 & 0,145 & 0,195 & 0,263 & 0,355 & 0,481 & 0,653 \\
\hline Exportação & 60,0 & 61,2 & 62,4 & 63,7 & 64,9 & 66,2 & 67,6 & 74,6 & 82,4 & 90,9 & 100,4 & 110,9 \\
\hline Total & 61,4 & 62,6 & 63,9 & 65,2 & 66,5 & 67,8 & 69,2 & 76,5 & 84,6 & 93,5 & 103,4 & 114,3 \\
\hline
\end{tabular}

Fonte: Elaboração Própria

\subsubsection{Exportação de Energia}

Uma das grandes características da região é a exportação de energia, sendo responsável por cerca de $60 \%$ da energia hidrelétrica do estado de São Paulo. Com cinco 
UHEs de grande porte, tem capacidade instalada de cerca de $6800 \mathrm{MW}$, o que se traduz em 60 TWh por ano.

Considerando que:

- O cenário tendencial não altera a percepção da exportação de energia e apenas se vale do PIR para satisfazer a demanda interna.

- O cenário sustentável assume o crescimento da exportação em $1 \%$ ao ano.

- Os cenários otimista e primoroso assumem um crescimento de $2 \%$ ao ano da exportação de energia.

No comparativo abaixo, são apresentadas as expectativas de exportação para cada cenário:

Tabela 25: expectativa de exportação de energia elétrica por cenário em GWh

\begin{tabular}{|c|c|c|c|c|c|c|c|c|c|c|c|c|}
\hline & 2008 & 2009 & 2010 & 2011 & 2012 & 2013 & 2014 & 2019 & 2024 & 2029 & 2034 & 2039 \\
\hline Tendencial & 60,0 & 60,0 & 60,0 & 60,0 & 60,0 & 60,0 & 60,0 & 60,0 & 60,0 & 60,0 & 60,0 & 60,0 \\
\hline Sustentável & 60,0 & 60,6 & 61,2 & 61,8 & 62,4 & 63,1 & 63,7 & 66,9 & 70,4 & 73,9 & 77,7 & 81,7 \\
\hline $\begin{array}{c}\text { Sustentável- } \\
\text { primoroso }\end{array}$ & 60,0 & 61,2 & 62,4 & 63,7 & 64,9 & 66,2 & 67,6 & 74,6 & 82,4 & 90,9 & 100,4 & 110,9 \\
\hline Otimista & 60,0 & 61,2 & 62,4 & 63,7 & 64,9 & 66,2 & 67,6 & 74,6 & 82,4 & 90,9 & 100,4 & 110,9 \\
\hline
\end{tabular}

Fonte: Elaboração Própria

\section{INTEGRAÇÃO DE RECURSOS}

\subsection{Integração dos Recursos}

O esquemático da Ilustração 22 apresenta o procedimento de integração de recursos energéticos de forma geral, dividido em quatro passos: 


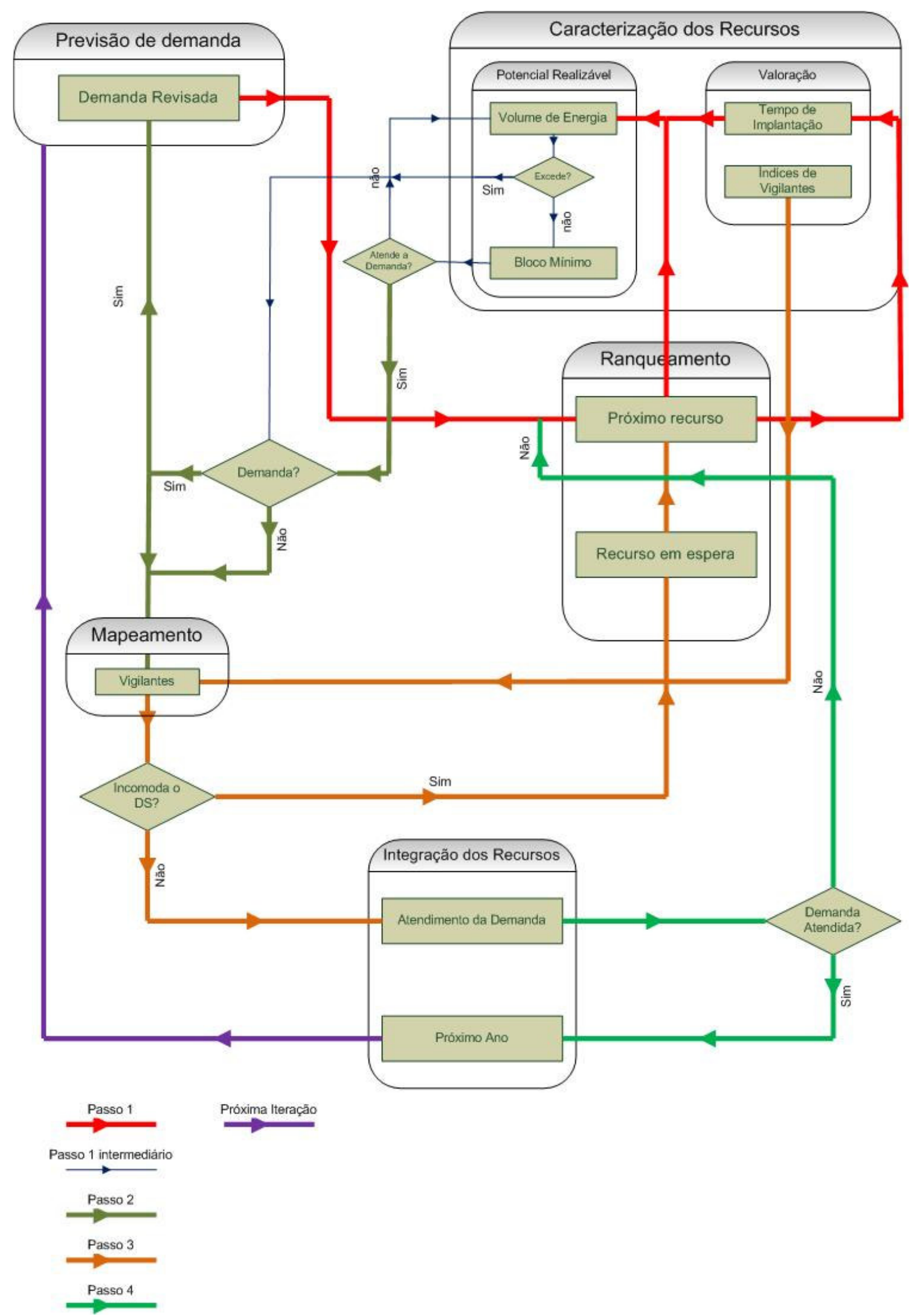

Ilustração 22: Esquemático da $\Sigma$ RE no PIR

Fonte: Elaboração Própria com base no Projeto FAPESP no 03/06441-7 


\section{Atendimento à Previsão de Demanda}

Consideração da previsão de demanda para a RAA, com necessidades de energia, perdas e margem de segurança. O Primeiro passo é a escolha do recurso melhor ranqueado na iteração para atendimento à demanda prevista. Após escolha inicial é consultado o tempo de implantação observando se é possível considerá-lo para este momento ${ }^{4}$ do planejamento. Após isso, verifica-se o volume de energia e, dentro disso, qual o bloco de mínima energia possível de se implantar do recurso considerado.

Dentro deste bloco é realizado um novo processo iterativo para consulta se o bloco mínimo é suficiente para atender à demanda, se sim leva ao passo 2 , se não, consulta-se o volume de energia do recurso para haver garantia que não se considere um volume maior que o disponível. Se é estourado leva primeiro ao passo 2, senão leva ao início do processo, somando a energia de mais um bloco mínimo.

\section{Revisão da Demanda.}

Processo simples que questiona se o recurso considerado na iteração vigente é do lado da demanda ou do lado da oferta. Se for RELO segue ao passo 3, se for RELD é necessário que, além de seguir ao passo 3, haja uma revisão da demanda para a próxima iteração. A revisão de demanda se dá devido às considerações de recursos de oferta já na construção dos cenários energéticos. Quando um RELD já está considerado e o ranqueamento pede a sua

${ }^{4}$ A observação é se o tempo já considerado permite que um recurso possa estar disponível naquele momento. Por exemplo, é possível considerar um recurso com tempo de implantação de 5 anos no $6^{\circ}$ ano do planejamento, mas não um recurso que leve 4 anos para ficar pronto no $3^{\circ}$ ano considerado. 
entrada, a demanda deve ser revista para que não haja consideração dupla do recurso no processo de integração.

\section{Consideração dos Vigilantes}

O passo busca informações no CVPC do recurso considerado sobre os vigilantes definidos para acompanhamento do Desenvolvimento Sustentável. Se a entrada do recurso naquele dado momento do planejamento causar algum incômodo ${ }^{5}$ quanto às premissas assumidas para o Desenvolvimento Sustentável da RAA, este recurso será mantido em espera, até que o retrato seja favorável à sua consideração no planejamento. Senão segue ao passo 4.

No esquemático, por conveniência visual, o recurso em espera entra novamente em consideração na iteração seguinte. Isso não é necessariamente verdade se o próximo recurso considerado não modificar o retrato do momento no mapeamento.

\section{Consideração do Recurso Enegético}

Ao passar pelo crivo dos vigilantes, o recurso e seu volume de energia parcial ou total é incluso no planejamento.

Então é verificado se a previsão da demanda foi atendida. Se sim, passa-se ao próximo ano das iterações e retorna-se ao passo 1 , senão, além de considerar o recurso da atual iteração, retorna-se ao passo 1 no mesmo ano desta iteração.

${ }^{5}$ Incômodo, na falta de uma expressão exata e adequada, refere-se ao retrato da RAA no momento determinado do planejamento. Quer dizer que os vigilantes não são necessariamente limites exatos ou imutáveis. Um recurso pode ser incômodo ao DS em um determinado momento e não o ser mais após um período ou consideração de outras premissas e recursos que modifiquem este retrato. 


\subsection{Incorporação de Ferramentas de Planejamento na Integração de Recursos}

\subsubsection{Ranqueamento de Recursos energéticos}

O ranqueamento de recursos energéticos é obtido a partir da aplicação da ACC de duas formas distintas que convergem para um único ranking de recursos energéticos (Cicone, 2008), sendo necessário que os atributos, sub-atributos e alternativas do CVPC e da aferição de opções no processo de ranqueamento dos En-in sejam idênticos para um posterior cruzamento de suas informações.

A primeira utilização se dá na chamada ACC determinística onde todas as avaliações atribuídas aos recursos energéticos são estimadas deterministicamente, através de normalizações de atributos qualitativos de forma sistemática para as dimensões Ambiental, Social e Político. Os dados são obtidos a partir do CVPC (Cicone, 2008).

Este tipo de utilização da ACC pode ser extremamente complexo pois todos os aspectos considerados devem ser valorados numericamente, seja na forma monetária, técnica ou em normalizações com valores por unidade para cada atributo. Pode-se dizer que todas as externalidades devem ser internalizadas de forma a serem consideradas quantitativamente. Apesar da dificuldade de cálculo, para um PIR completo e rigoroso deve-se contar com essas informações.

Ainda sobre a ACC determinística, ao contrário das notas dos recursos que são calculadas deterministicamente, os pesos dos sub-atributos devem ser calculados holisticamente pelos especialistas da região. Para este procedimento é utilizada a comparação par-a-par dentro do Processo Analítico Hierárquico - PAH (Reinig, 2008). 
A segunda utilização é realizada na ACC estimada pelos En-In. Esta avaliação é totalmente holística e os sub-atributos são comparados entre si como na ACC determinística, porém com a opção de todos os En-In e os recursos são avaliados com relação aos subatributos holisticamente. Essa avaliação é feita utilizando uma escala verbal, que também está inserida dentro da metodologia de tomada de decisão do PAH (Cicone, 2008)

\section{A ACC Determinística no PIR da Região de Araçatuba}

Inicialmente devem ser determinados os pesos dos sub-atributos da árvore de decisão. Tais pesos são resultado da valoração realizada por especialistas da RAA, e suas avaliações holísticas sobre os recursos analisados.

A avaliação holística se dá devido ao fato de que análises quantitativas entre subatributos com escalas e unidades diferentes não fazem sentido, ou seja, pode se comparar recursos com essa ferramenta, pois, por exemplo, a geração de empregos para a implantação de um recurso eólico pode ser comparada com a geração de empregos para a implantação de recursos nucleares. Porém não cabe a comparação determinística entre a geração de empregos e a emissão de efluentes no meio aquático.

\section{A ACC Holística da Região de Araçatuba}

Como o próprio nome subentende o intuito desse exercício, a ACC holística leva em conta a opinião dos En-In para a composição dos pesos de cada sub-atributo, assim como a classificação dos recursos a partir da aferição de opções após oficinas explanatórias. 


\section{O Ranking dos recursos}

O ranking propriamente dito não determina um vencedor ou vencedores. A sua aplicação traz a ordem em que os recursos devem ser implantados para que a demanda seja atendida com o menor custo completo para o cenário determinado.

\section{Tabela 26: Rankinq dos recursos considerados}

\begin{tabular}{|c|c|c|c|}
\hline & & $\begin{array}{c}\text { Volume de } \\
\text { EnergiaGWh }\end{array}$ & $\begin{array}{c}\text { Bloco } \\
(\mathrm{MWh})\end{array}$ \\
\hline $1^{\circ}$ & solar coletor & 199,2 & 1,04 \\
\hline $2^{\circ}$ & Eólico & 13215 & 7000 \\
\hline $3^{\circ}$ & etanol & 41440 & 414 \\
\hline $4^{\circ}$ & solar pv & 7725 & 31,2 \\
\hline $5^{\circ}$ & biodiesel & 1056 & 414 \\
\hline
\end{tabular}

Fonte: Elaboração Própria

Cabe aqui a discussão da aplicação do presente trabalho como uma carteira de recursos preferenciais, ou especiais. Que são priorizadas em detrimento a outros recursos que podem e devem ser considerados no PIR completo.

Para a aplicação específica realizada neste trabalho, a consideração das fontes renováveis em questão são suficientes para o atendimento da demanda sem nenhuma quebra de premissa do Desenvolvimento Sustentável.

\subsubsection{Mapeamento Energoambiental}

O mapeamento, alimentado pelo Inventário energoambiental prévio, traz um retrato momentâneo da região nos meios aéreo, aquático, terrestre e antrópico. Este retrato serve como indicador que aqui será chamado de vigilante pois não é uma barreira física, clara e intransponível, mas sim uma sentinela do Desenvolvimento Sustentável, sendo mutável ao 
longo do horizonte de planejamento, de acordo com premissas dos cenários e utilização de recursos.

O mapeamento é afetado pela utilização dos recursos energéticos disponíveis e na metodologia do PIR também afeta essa utilização possibilitando que, mapeando as diversas variáveis ambientais da RAA, se escolha um determinado recurso energético em detrimento a outro apesar de o ranqueamento ordena-los de forma contrária.

Essa consideração deve ser dinâmica e acompanhar os cenários de previsão de demanda, sendo possível que um recurso tenha sido barrado no planejamento em um determinado momento e, com a entrada de novas premissas ou a inclusão de recursos que melhorem a condição de algum vigilante. Para a RAA, foram considerados os vigilantes da Tabela 27.

Tabela 27: Vigilantes do Mapeamento Energoambiental para a RAA

\begin{tabular}{|c|c|c|c|c|}
\hline \multirow{3}{*}{ Meio Aquático } & \multicolumn{2}{|c|}{ DBO e DQO (Kg/DBO/dia/hab) } & \multicolumn{2}{|c|}{ Demanda hídrica (mil m3/ano) } \\
\hline & Potencial & Remanescente & total & disponível \\
\hline & 19884 & 9862 & 338297,184 & 580262,4 \\
\hline \multirow{3}{*}{ Meio Aéreo } & \multicolumn{2}{|c|}{ Material Particulado MP10 $\left(\mu \mathrm{g} / \mathrm{m}^{3}\right)$} & \multicolumn{2}{|c|}{ Ozônio $\left(\mu \mathrm{g} / \mathrm{m}^{3}\right)$} \\
\hline & média RAA & limite & Média & limite \\
\hline & 27,5 & 50 & 40 & 100 \\
\hline \multirow{2}{*}{ Meio Terrestre } & \multicolumn{2}{|c|}{ Areas impróprias(somatória de ocorrências) } & \multicolumn{2}{|c|}{ Vegetação Remanescente } \\
\hline & \multicolumn{2}{|c|}{41} & \multicolumn{2}{|c|}{3,49} \\
\hline \multirow{3}{*}{ Meio Antrópico } & \multicolumn{2}{|c|}{ IDH } & \multicolumn{2}{|c|}{ Habitantes/km2 } \\
\hline & média RAA & Mínimo & \multicolumn{2}{|c|}{ Média } \\
\hline & 0,777 & 0,729 & \multicolumn{2}{|c|}{38,91} \\
\hline
\end{tabular}




\subsection{Aplicação da Integração dos Recursos para a RAA}

A idéia inicial da aplicação deveria ser uma carteira completa em que se priorizariam os recursos aqui listados, porém a disponibilidade de se atender mesmo a demanda de exportação do cenário mais exigente em volume de energia faz com que a aplicação se torne exclusiva dos recursos.

Como se tratam de recursos que exemplificam bem uma aplicação da metodologia PIR, com RELOs e RELDs considerados de forma única e com a $\Sigma$ RE caracterizada com cinco diferentes recursos, optou-se por aplicar apenas os recursos aqui listados.

\subsubsection{Premissas de Atendimento à Demanda da RAA}

A energia disponível à cada iteração ao longo do horizonte de planejamento deve satisfazer o consumo dos setores, as perdas características de cada cenário. e possibilitar uma margem de segurança de operação de $15 \%$.

Para a RAA, margem de segurança de operação estará sempre dentro da energia exportada, uma vez que o consumo interno é consideravelmente inferior mesmo extrapolando-se a mais otimista das otimizações dos cenários.

O ano de 2008 na construção dos cenários refere-se ao ano zero, ao ponto de partida dos dados do ano base.

Para o primeiro ano do planejamento, se o recurso melhor ranqueado não atender a demanda devido ao tempo de implantação, seguirá a classificação até o recurso que atenda a este ano, porém a aplicação do primeiro recurso se dará de forma que ele entre o mais rápido possível, e isso se repete ao longo do planejamento. Como exemplo, se no ano 15 do 
planejamento se identifica a necessidade de um recurso que demora 2 anos para ser implantado, ele entrará no ano 15 assumindo que começou a ser construído no ano 13. contudo, se este recurso é selecionado para o ano 1 do planejamento, ele será construído e estará disponível no ano 3, mas outros recursos serão implantados com o intuito de atender à demanda nos anos 1 e 2 .

O potencial de coletores solares estará disponível a um máximo de 1/3 do total a cada ano devido a fatores de mercado, pois o seu custo elevado arcado pelo próprio consumidor impede que todo o seu potencial seja considerado disponível de imediato.

O ranking dos recursos, apesar de a metodologia de PIR necessitar de uma reavaliação ano a ano, não é modificado, ou seja, a classificação dos recursos é a mesma do início ao fim.

Os volumes de energia e blocos mínimos considerados são apresentados na Tabela 28.

Tabela 28: Volume de energia e bloco mínimo por recurso

\begin{tabular}{|c|c|c|c|}
\hline & $\begin{array}{c}\text { Volume } \\
\text { de } \\
\text { Energia } \\
\text { (GWh) }\end{array}$ & $\begin{array}{c}\text { Bloco } \\
\text { (MWh) }\end{array}$ & $\begin{array}{c}\text { Tempo de } \\
\text { implantação }\end{array}$ \\
\hline $\begin{array}{c}\text { solar } \\
\text { coletor }\end{array}$ & 199,2 & 1,04 & 6 \\
\hline Eólico & 13215 & 7000 & 24 \\
\hline etanol & 41440 & 414 & 1 \\
\hline solar pv & 7725 & 31,2 & 1 \\
\hline biodiesel & 1056 & 414 & 1 \\
\hline
\end{tabular}




\section{Resultados e Conclusões}

\subsection{Resultados para o Cenário Tendencial}

A Tabela 29 apresenta os requerimentos de demanda para o cenário tendencial considerando as perdas de transmissão.

Tabela 29: Demanda requerida para o Cenário Tendencial (mil MWh)

\begin{tabular}{|c|c|c|c|c|c|c|c|c|c|c|c|c|}
\hline ano & 08 & 09 & 10 & 11 & 12 & 13 & 14 & 19 & 24 & 29 & 34 & 39 \\
\hline Exportação & 60,00 & 60,00 & 60,00 & 60,00 & 60,00 & 60,00 & 60,00 & 60,00 & 60,00 & 60,00 & 60,00 & 60,00 \\
\hline Total & 61,36 & 61,39 & 61,43 & 61,47 & 61,51 & 61,55 & 61,59 & 61,80 & 62,05 & 62,34 & 62,68 & 63,08 \\
\hline Incremento & & 0,04 & 0,04 & 0,04 & 0,04 & 0,04 & 0,04 & 0,22 & 0,25 & 0,29 & 0,34 & 0,4 \\
\hline Com Perdas & & 0,04 & 0,04 & 0,04 & 0,04 & 0,05 & 0,05 & 0,25 & 0,29 & 0,33 & 0,39 & 0,46 \\
\hline
\end{tabular}

Fonte: Elaboração Própria

A integração dos recursos para o cenário tendencial atende completamente a demanda requerida, como pode ser visto na Tabela 30 onde se pode especificar nas linhas o potencial em GWh utilizado de cada fonte, a falta atend. especifica o quanto falta para atendimento à demanda, sendo os valores negativos indicativos de sobra de energia.

Já no remanescente, as linhas representam o potencial remanescente por fonte energética. 
Tabela 30: Atendimento à demanda do cenário Tendencial (GWh)

\begin{tabular}{|c|c|c|c|c|c|c|c|c|c|c|c|}
\hline & $\begin{array}{c}1^{0} \\
\text { ano } \\
\end{array}$ & $\begin{array}{c}2^{0} \\
\text { ano } \\
\end{array}$ & $\begin{array}{c}3^{\circ} \\
\text { ano } \\
\end{array}$ & $\begin{array}{c}4^{0} \\
\text { ano } \\
\end{array}$ & $\begin{array}{c}5^{\circ} \\
\text { ano } \\
\end{array}$ & $\begin{array}{c}6^{0} \\
\text { ano }\end{array}$ & $\begin{array}{l}10^{\circ} \\
\text { ano } \\
\end{array}$ & $\begin{array}{l}15^{\circ} \\
\text { ano } \\
\end{array}$ & $\begin{array}{l}20^{\circ} \\
\text { ano } \\
\end{array}$ & $\begin{array}{l}25^{\circ} \\
\text { ano } \\
\end{array}$ & $\begin{array}{l}30^{\circ} \\
\text { ano } \\
\end{array}$ \\
\hline $\begin{array}{c}\text { solar } \\
\text { coletor }\end{array}$ & 42 & 42 & 43 & 44,4 & 27,8 & & & & & & \\
\hline Eólico & & & & & 21 & 45 & 252 & 287 & 336 & 385 & 462 \\
\hline etanol & & & & & & & & & & & \\
\hline solar pv & & & & & & & & & & & \\
\hline biodiesel & & & & & & & & & & & \\
\hline $\begin{array}{c}\text { falta } \\
\text { atend. }\end{array}$ & $-0,95$ & $-0,74$ & $-0,27$ & $-0,05$ & $-2,96$ & $-2,2$ & $-4,65$ & $-3,46$ & $-5,38$ & $-0,07$ & $-5,75$ \\
\hline & \multicolumn{11}{|c|}{ Remansecente } \\
\hline $\begin{array}{c}\text { solar } \\
\text { coletor }\end{array}$ & 157,2 & 115,2 & 72,2 & 27,8 & 0 & 0 & 0 & 0 & 0 & 0 & 0 \\
\hline Eólico & 13215 & 13215 & 13215 & 13215 & 13194 & 13149 & 12897 & 12610 & 12274 & 11889 & 11427 \\
\hline etanol & 41440 & 41440 & 41440 & 41440 & 41440 & 41440 & 41440 & 41440 & 41440 & 41440 & 41440 \\
\hline solar pv & 7725 & 7725 & 7725 & 7725 & 7725 & 7725 & 7725 & 7725 & 7725 & 7725 & 7725 \\
\hline biodiesel & 1056 & 1056 & 1056 & 1056 & 1056 & 1056 & 1056 & 1056 & 1056 & 1056 & 1056 \\
\hline
\end{tabular}

Fonte: Elaboração Própria

\subsection{Resultados para o Cenário Sustentável}

A Tabela 31 apresenta os requerimentos da demanda para cenário sustentável e a Tabela 32 a integração dos recursos para atendimento desta demanda.

Tabela 31: Requerimentos da demanda do cenário Sustentável (mil MWh)

\begin{tabular}{|c|c|c|c|c|c|c|c|c|c|}
\hline ano & 08 & 12 & 13 & 14 & 19 & 24 & 29 & 34 & 39 \\
\hline Exportação & 60,0 & 62,4 & 63,1 & 63,7 & 66,9 & 70,4 & 73,9 & 77,7 & 81,7 \\
\hline Total & 61,4 & 63,8 & 64,4 & 65,0 & 68,3 & 71,7 & 75,3 & 79,1 & 83,0 \\
\hline Incremento & & 0,619 & 0,625 & 0,630 & 3,245 & 3,410 & 3,582 & 3,763 & 3,953 \\
\hline $\begin{array}{c}\text { Com } \\
\text { Perdas }\end{array}$ & & 0,656 & 0,662 & 0,668 & 3,440 & 3,614 & 3,797 & 3,989 & 4,190 \\
\hline
\end{tabular}

Fonte: Elaboração Própria 
Tabela 32: Atendimento da demanda para o cenário Sustentável (mil MWh)

\begin{tabular}{|c|c|c|c|c|c|c|c|c|c|c|c|}
\hline & $\begin{array}{c}1^{\circ} \\
\text { ano }\end{array}$ & $2^{\circ}$ ano & $\begin{array}{c}3^{\circ} \\
\text { ano }\end{array}$ & $\begin{array}{c}4^{\circ} \\
\text { ano }\end{array}$ & $\begin{array}{c}5^{\circ} \\
\text { ano }\end{array}$ & $\begin{array}{c}6^{\circ} \\
\text { ano }\end{array}$ & $\begin{array}{c}10^{\circ} \\
\text { ano }\end{array}$ & $\begin{array}{c}15^{\circ} \\
\text { ano }\end{array}$ & $\begin{array}{c}20^{\circ} \\
\text { ano }\end{array}$ & $\begin{array}{c}25^{\circ} \\
\text { ano }\end{array}$ & $\begin{array}{c}30^{\circ} \\
\text { ano }\end{array}$ \\
\hline $\begin{array}{c}\text { solar } \\
\text { coletor }\end{array}$ & 66,4 & 66,4 & 66,4 & & & & & & & & \\
\hline Eólico & & & 644 & 655 & 658 & 672 & 3437 & 3619 & 3530 & & \\
\hline etanol & 624,3 & 631,22 & & & & & & & 260,8 & 3989 & 4191 \\
\hline solar pv & & & & & & & & & & & \\
\hline biodiesel & & & & & & & & & & & \\
\hline $\begin{array}{c}\text { falta } \\
\text { atend. }\end{array}$ & 0,0 & 0,0 & $-6,1$ & $-5,2$ & $-0,8$ & $-5,2$ & $-2,1$ & $-6,7$ & $-0,2$ & 0,0 & $-0,5$ \\
\hline $\begin{array}{c}\text { solar } \\
\text { coletor }\end{array}$ & 132,8 & 66,4 & 0 & 0 & 0 & 0 & 0 & 0 & 0 & 0 & 0 \\
\hline Eólico & 13215 & 13215 & 12571 & 11916 & 11258 & 10586 & 7149 & 3530 & 0 & 0 & 0 \\
\hline etanol & 40816 & 40184 & 40184 & 40184 & 40184 & 40184 & 40184 & 40184 & 39924 & 35935 & 31744 \\
\hline solar pv & 7725 & 7725 & 7725 & 7725 & 7725 & 7725 & 7725 & 7725 & 7725 & 7725 & 7725 \\
\hline biodiesel & 1056 & 1056 & 1056 & 1056 & 1056 & 1056 & 1056 & 1056 & 1056 & 1056 & 1056 \\
\hline
\end{tabular}

Fonte: Elaboração Própria

\subsection{Resultados para o Cenário Otimista}

A Tabela 33 a seguir mostra os requerimentos de energia para o cenário otimista com o incremento entre período e as perdas por transmissão.

Tabela 33: requerimento de energia do Cenário Otimista com perdas (mil GWh)

\begin{tabular}{|c|c|c|c|c|c|c|c|c|c|c|c|c|}
\hline & 2008 & 2009 & 2010 & 2011 & 2012 & 2013 & 2014 & 2019 & 2024 & 2029 & 2034 & 2039 \\
\hline Exportação & 60,00 & 61,20 & 62,42 & 63,67 & 64,95 & 66,24 & 67,57 & 74,60 & 82,37 & 90,94 & 100,41 & 110,86 \\
\hline Total & 61,36 & 62,60 & 63,87 & 65,16 & 66,48 & 67,83 & 69,20 & 76,49 & 84,56 & 93,49 & 103,38 & 114,3 \\
\hline incremento & 0,000 & 1,242 & 1,268 & 1,293 & 1,320 & 1,347 & 1,373 & 7,295 & 8,070 & 8,929 & 9,885 & 10,94 \\
\hline perdas & 0,000 & 1,429 & 1,458 & 1,487 & 1,518 & 1,549 & 1,579 & 8,390 & 9,280 & 10,268 & 11,368 & 12,59 \\
\hline
\end{tabular}

Fonte: Elaboração Própria

A Tabela 34 apresenta o atendimento à demanda local e de exportação com a integração dos recursos energéticos listados, apresentando a energia remanescente do potencial total do recurso a ser aproveitado. 
Tabela 34: Previsão do atendimento da demanda com os recursos disponíveis (em mil MWh)

\begin{tabular}{|c|c|c|c|c|c|c|c|c|c|c|c|}
\hline & $\begin{array}{c}1^{\circ} \\
\text { ano }\end{array}$ & $\begin{array}{c}2^{0} \\
\text { ano }\end{array}$ & $\begin{array}{c}3^{\circ} \\
\text { ano } \\
\end{array}$ & $\begin{array}{c}4^{0} \\
\text { ano } \\
\end{array}$ & $\begin{array}{c}5^{0} \\
\text { ano } \\
\end{array}$ & $\begin{array}{c}6^{0} \\
\text { ano } \\
\end{array}$ & $\begin{array}{l}10^{\circ} \\
\text { ano }\end{array}$ & $\begin{array}{l}15^{\circ} \\
\text { ano } \\
\end{array}$ & $\begin{array}{l}20^{\circ} \\
\text { ano }\end{array}$ & $\begin{array}{l}25^{\circ} \\
\text { ano }\end{array}$ & $\begin{array}{l}30^{\circ} \\
\text { ano }\end{array}$ \\
\hline $\begin{array}{c}\text { solar } \\
\text { coletor }\end{array}$ & 66,4 & 66,4 & 66,4 & & & & & & & & \\
\hline Eólico & & & 1421 & 1519 & 1554 & 1575 & 7146 & & & & \\
\hline etanol & 1363 & 1391 & & & & & 1241 & 9280 & 10268 & 11368 & 6529 \\
\hline solar pv & & & & & & & & & & & 6061 \\
\hline biodiesel & & & & & & & & & & & \\
\hline falta atend. & $-1,06$ & $-0,34$ & $-0,33$ & $-1,56$ & $-6,86$ & $-3,14$ & $-0,19$ & $-0,37$ & $-0,28$ & $-0,209$ & $-0,045$ \\
\hline & \multicolumn{11}{|c|}{ Remansecente } \\
\hline $\begin{array}{c}\text { solar } \\
\text { coletor }\end{array}$ & 132,8 & 66,4 & 0 & 0 & 0 & 0 & 0 & 0 & 0 & 0 & 0 \\
\hline Eólico & 13215 & 13215 & 11794 & 10275 & 8721 & 7146 & 0 & 0 & 0 & 0 & 0 \\
\hline etanol & 40077 & 38686 & 38686 & 38686 & 38686 & 38686 & 37445 & 28165 & 17897 & 6529 & 0 \\
\hline solar pv & 7725 & 7725 & 7725 & 7725 & 7725 & 7725 & 7725 & 7725 & 7725 & 7725 & 1664 \\
\hline biodiesel & 1056 & 1056 & 1056 & 1056 & 1056 & 1056 & 1056 & 1056 & 1056 & 1056 & 1056 \\
\hline
\end{tabular}

Fonte: Elaboração própria

Pode se notar ainda que nenhum dos vigilantes incomoda o Desenvolvimento sustentável da região

\subsection{Resultados para o Cenário Sustentável-Primoroso}

A Tabela 35 apresenta os requerimentos de demanda para o cenário sustentávelprimoroso.

Tabela 35: Requerimentos da demanda para o cenário Sustentável- Primoroso

\begin{tabular}{|c|c|c|c|c|c|c|c|c|c|}
\hline ano & 08 & 12 & 13 & 14 & 19 & 24 & 29 & 34 & 39 \\
\hline Exportação & 60,0 & 64,9 & 66,2 & 67,6 & 74,6 & 82,4 & 90,9 & 100,4 & 110,9 \\
\hline Total & 61,4 & 66,3 & 67,6 & 68,9 & 75,9 & 83,6 & 92,0 & 101,4 & 111,7 \\
\hline Incremento & & 1,27 & 1,29 & 1,32 & 7,00 & 7,67 & 8,46 & 9,36 & 10,34 \\
\hline Com Perdas & & 1,40 & 1,42 & 1,45 & 7,70 & 8,44 & 9,31 & 10,29 & 11,38 \\
\hline
\end{tabular}

Fonte: Elaboração própria

A integração dos recursos para o requerimento da demanda é apresentado na Tabela 36 com o potencial de energia de entrada em cada ano do planejamento. 
Tabela 36: Sre para atendimento da demanda no cenário sustentável-primoroso

\begin{tabular}{|c|c|c|c|c|c|c|c|c|c|c|c|}
\hline & $\begin{array}{c}1^{\circ} \\
\text { ano }\end{array}$ & $\begin{array}{c}2^{\circ} \\
\text { ano }\end{array}$ & $\begin{array}{c}3^{\circ} \\
\text { ano }\end{array}$ & $\begin{array}{c}4^{\circ} \\
\text { ano }\end{array}$ & $\begin{array}{c}5^{\circ} \\
\text { ano }\end{array}$ & $\begin{array}{c}6^{\circ} \\
\text { ano }\end{array}$ & $\begin{array}{l}10^{\circ} \\
\text { ano }\end{array}$ & $\begin{array}{l}15^{\circ} \\
\text { ano }\end{array}$ & $\begin{array}{l}20^{\circ} \\
\text { ano }\end{array}$ & $\begin{array}{l}25^{\circ} \\
\text { ano }\end{array}$ & $\begin{array}{l}30^{\circ} \\
\text { ano }\end{array}$ \\
\hline $\begin{array}{l}\text { solar } \\
\text { coletor }\end{array}$ & 66,4 & 66,4 & 66,4 & & & & & & & & \\
\hline Eólico & & & 1365 & 1400 & 1421 & 1449 & 7580 & & & & \\
\hline etanol & 1314 & 1336 & & & & & 116 & 8434 & 9309 & 10290 & 10640 \\
\hline solar pv & & & & & & & & & & & 735,1 \\
\hline \multicolumn{12}{|l|}{ biodiesel } \\
\hline $\begin{array}{c}\text { falta } \\
\text { atend. }\end{array}$ & $-0,6$ & $-0,52$ & $-1,66$ & $-6,21$ & $-3,81$ & $-2,23$ & $-0,55$ & 0,275 & $-0,49$ & $-0,08$ & $-0,08$ \\
\hline & \multicolumn{11}{|c|}{ Remansecente } \\
\hline $\begin{array}{l}\text { solar } \\
\text { coletor }\end{array}$ & 132,8 & 66,4 & 0 & 0 & 0 & 0 & 0 & 0 & 0 & 0 & 0 \\
\hline Eólico & 13215 & 13215 & 11850 & 10450 & 9029 & 7580 & 0 & 0 & 0 & 0 & 0 \\
\hline etanol & 40126 & 38790 & 38790 & 38790 & 38790 & 38790 & 38674 & 30240 & 20931 & 10641 & 0,5 \\
\hline solar pv & 7725 & 7725 & 7725 & 7725 & 7725 & 7725 & 7725 & 7725 & 7725 & 7725 & 6990 \\
\hline biodiesel & 1056 & 1056 & 1056 & 1056 & 1056 & 1056 & 1056 & 1056 & 1056 & 1056 & 1056 \\
\hline
\end{tabular}

Fonte: Elaboração própria

\subsection{Conclusões}

\subsubsection{Acerca do Planejamento Energético}

O planejamento energético deve enxergar, para uma aplicação coerente e passível de Desenvolvimento Sustentável, a natureza da região de aplicação em si. Abstraindo-se da figura do mercado, do meio-ambiente ou da sociedade, mas valendo-se deles para legitimar essa abstração e assim conseguir uma combinação de elementos incorporados a esse planejamento que possibilite o menor custo completo ao longo do seu horizonte. E a metodologia PIR vem atender essa necessidade buscando o ótimo ao longo do tempo em todos os aspectos.

O Desenvolvimento Sustentável pode e deve ser objetivo do Planejamento Energético sem que haja perda de qualquer natureza para a sociedade. Pelo contrário, conseguindo 
ganhos ainda maiores em áreas antes olvidadas e que serão ganhos ainda maiores para gerações futuras que usufruirão destas possibilidades.

\subsubsection{Acerca dos Resultados}

Os resultados obtidos com a integração dos recursos a partir da metodologia de PIR permitem verificar conforme o recurso é implantado as possibilidades de utilização do seu potencial energético completo e os requerimentos da demanda para utilização, além de possibilitar o planejamento de comercialização de excedentes da demanda.

A análise dos resultados permitem observar que os recursos selecionados atenderam apropriadamente os requisitos de demanda com o menor custo completo, mesmo no cenário mais otimista de crescimento de utilização e exportação de energia. Porém fica claro que, nos casos dos cenários Otimista e Sustentável-Primoroso, a busca por novas fontes de energia se faz necessária logo após o horizonte de 30 anos do planejamento.

Em nenhum dos casos, a utilização do biodiesel se apresentou necessária para o suprimento da demanda por energia na RAA. Isto não o faz desnecessário ou descartável no PIR, já que a o exercício aqui realizado contempla apenas a energia elétrica. Ficando como proposição a novos trabalhos estudos que permitam o entrelaçamento da produção de etanol e utilização do biodiesel para transporte, com a possibilidade de produção in-loco do biodiesel através da rota etílica de transesterificação.

\section{REFERÊNCIAS BIBLIOGRÁFICAS}

[1] Aristóteles, "Ética a Nicômaco", ????

[2] PNUMA, "Report of the World Commission on Environment and Development: Our Common Future”, 1987 
[3] SEADE, "Balanço Energético do Estado de São Paulo 2007 - Ano Base 2006", 2007

[4] EPE, "Balanço Energético Nacional 2007 - Ano Base 2006”, 2007

[5] IBGE, "Programa Nacional de Amostragem de Domicílios PNAD 2007”,

[6] PROCEL, "Pesquisa de Posse de Equipamentos e Hábitos de Uso - Classe Residencial Relatório Sudeste - Ano Base 2005”, 2008

[7] PROCEL, "Pesquisa de posse de Equipamentos e Hábitos de Uso - Classe Industrial - Ano Base 2005”, 2008

[8] Banco de Dados Fundação SEADE, acesso em novembro de 2007

[9] Fundación Bariloche, "La Construcción de Escenarios Socioeconômicos para la Prospectiva Energética”, 2008

[10]BRAVO, V. "La Construcción de Escenarios Energéticos””,. Bariloche, 2008

[11]Jannuzzi, G.M., "Power Sector Reforms in Brazil and its Impacts on Energy Efficiency and Research Development Activities”, Energy Policy, 2005

[12] Castro, R. M. G. "Energias Renováveis e Produção Descentralizada. Introdução à Energia Eólica”, , Universidade Técnica de Lisboa, 2007

[13]ANEEL. Atlas de energia elétrica do Brasil. Em www.aneel.gov.br

[14]BAITELO, R. L. Modelagem Completa e Análise dos Recursos Energéticos do Lado da Demanda para o PIR. Dissertação (mestrado) - Escola Politécnica, Universidade de São Paulo, São Paulo, 2006.

[15]FUJII, R. J “Modelo de Caracterização Sistêmica das Opções de Oferta Energética para o PIR”. Dissertação DE Mestrado - Escola Politécnica, Universidade de São Paulo, São Paulo, 2006. 
[16]BOARATI, J.H.; "Um Modelo para Avaliação Ponderada da Hidroeletricidade e Termeletricidade com Gás Natural através dos Custos Completos", Dissertação de mestrado apresentada à EPUSP, São Paulo, 2003

[17] CARVAlHO, C. E.; “A Análise do Ciclo de Vida e os Custos Completos no Planejamento Energético”, Dissertação de mestrado, PEA - USP, São Paulo, 2000.

[18]CARVAlHO, C. E. Desenvolvimento de Procedimentos e Métodos para Mensuração e Incorporação das Externalidades em Projetos de Energia Elétrica: Uma Aplicação às Linhas de Transmissão Aéreas. Tese (doutorado) - Escola Politécnica, Universidade de São Paulo, São Paulo, 2005.

[19]DOE - Department of Energy - EUA. Renewable Energy Technology Characterizations. Office of Utility Tecnologies, Washington, D. C., 2000.

[20]UDAETA; M. E. M. et al. Relatório Técnico - Anexo 3. Projeto Fapesp - Novos Instrumentos de Planejamento Energético Regional Visando o Desenvolvimento Sustentável. Relatório Técnico. Escola Politécnica, Universidade de São Paulo, São Paulo, 2004.

[21]UDAETA; M. E. M., et alii; "Relatórios de Visitas e Entrevistas em Araçatuba", PEA - USP, São Paulo, 2004.

[22]FUJII, R. J., FRANCO, D. G., UDAETA, M. E. M., GIMENES, A. L. V.; "Recursos Distribuídos de Energia do Estado de São Paulo", Projeto de formatura, PEA - USP, São Paulo, 2002.

[23] GIMENES, A.L.V.; UDAETA, M.E.M. "Modelo de Integração de Recursos como Instrumento para um Planejamento Energético Sustentável", Tese de doutorado apresentada à Escola Politécnica da Universidade de São Paulo, São Paulo, (2004)

[24] GOLDEMBERG, J. Energia, Meio Ambiente \& Desenvolvimento. Edusp. São Paulo, 1998. 
[25] LEAP - Long-range Energy Alternatives Planning System; UserGuide for version 2000. Boston Center - Tellus Institute, Boston, 2001.

[26]NISHIMARU, R. S. Opções Energéticas de Pico-Geração Na RDS Mamirauá Projeto de Formatura - Escola Politécnica, Universidade de São Paulo, São Paulo, 2003.

[27]REIS, L. B. D. Geração de Energia Elétrica - Tecnologia, Inserção Ambiental, Planejamento, Operação e Análise de Viabilidade. Editora Manole, Barueri, 2003.

[28]SAATY, T. L.. Método de Análise Hierárquica. McGraw-Hill Ltda. e Makron Books do Brasil Editora Ltda., 1991.

[29]SAUER, I.L.; UDAETA, M.E.M.; GIMENES， A.L.V.; GALVÃO， L.C.R.; CARVALHO, C.E.; "Brazilian Energy Prospects Seeking The Sustainable Development"; IAEE, 2003

[30] SAUER, I. "Estudo de Planejamento Integrado de Recursos para o Sistema Elétrico de Boa Vista RR”. Instituto de Eletrotécnica e Energia da Universidade de São Paulo, 2004.

[31] Secretaria de Economia e Planejamento do Estado de São Paulo. Uma proposta de agenda para 2020: Região Administrativa de Araçatuba. São Paulo, 2001.

[32]UDAETA, M.E.M. "Planejamento Integrado de Recursos Energéticos para o Setor Elétrico - PIR - Pensando o Desenvolvimento Sustentado". Tese de Doutorado, Escola Politécnica da Universidade de São Paulo. Brasil, 1997

[33]UDAETA, M.E.M.; GIMENES, A.L.V.; GALVÃO, L.C.R.; REIS， L.B.; CARVALHO, C.E.; " Brazilian Energy Outlook For The Next Five Years: A Critical Overview About Energy Economics And Forecasts" 18th WEC - World Energy Congress, 21 a 25 de outubro de 2001, Buenos Aires Argentina. 
[34]UDAETA, M.E.M.; GIMENES, A.L.V.; GALVÃO, L.C.R.; CARVALHO, C.E. "Power Production With Natural Gas Under the Concept of the Local IRP Application". 25th International Association of Energy Economics - IAEE International Conference, 26 a 29 de junho de 2002, Aberdeen - Escócia.

[35]UDAETA, M.E.M., GALVÃO, L.C.R. “Alternativas Energéticas do Oeste Paulista"-Artigo Técnico, X Congresso Brasileiro de Energia, COPPE/UFRJ, Rio de Janeiro, 2004.

[36]UDAETA, M.E.M., GRIMONI, J.A.B. "Modelo Institucional do Setor Elétrico" Relatório Técnico. Departamento de Energia e Automação da Escola Politécnica da Universidade de São Paulo. São Paulo, 2004.

[37]UDAETA, M.E.M., RIBEIRO, F.S. "Novos Instrumentos de Planejamento Energético Regional visando o Desenvolvimento Sustentável”- Relatório Técnico da Etapa 1 - São Paulo, 2004.

[38]UDAETA, M.E.M., GALVÃO, L.C.R. “Avaliação Prévia do PIR para uma Reserva de Desenvolvimento Sustentável”- Artigo Técnico, X Congresso Brasileiro de Energia, COPPE/UFRJ, Rio de Janeiro, 2004.

[39]UDAETA, M.E.M., GALVÃO, L.C.R. "Elementos de Planejamento Integrado de Recursos Energéticos"- Artigo Técnico, X Congresso Brasileiro de Energia, COPPE/UFRJ, Rio de Janeiro, 2004.

[40]UDAETA, M. E .M.; GIMENES, A. L. V.; GALVÃO, L.C.R; BAITELO, R.L. Estado de Arte e Síntese dos Trabalhos realizados no GEPEA acerca do PIR na Fase II. Relatório Técnico. Escola Politécnica, Universidade de São Paulo, 2004.

[41]UDAETA, M.E.M., et al. "Sistema de Análise Energética para os Usos Finais no Estado de São Paulo" Relatórios 1, 2 e 3 - Pesquisa para SESP e CTEEP. São Paulo, 2006. 
[42]UDAETA, M.E.M., BAITELO, R.L. “Aspectos Políticos do Gerenciamento do Lado da Demanda”. CBR - Congresso Brasileiro de Regulação, Manaus, 2005.

[43]UDAETA, M.E.M., BAITELO, R.L. “Aspectos Políticos do Gerenciamento do Lado da Demanda”. CBR - Congresso Brasileiro de Regulação, Manaus, 2005.

[44]UDAETA, M.E.M., BAITELO, R.L. “Aspectos Políticos do Gerenciamento do Lado da Demanda”. CBR - Congresso Brasileiro de Regulação, Manaus, 2005.

[45] UDAETA, M.E.M., et alii; "Relatório Técnico Científico Parcial 1 - Relatórios de Visitas em Araçatuba”, PEA - USP, São Paulo, 2006.

[46]UDAETA, M.E.M., et alii; “Relatório Técnico Científico Parcial 1- Oficina de PIR - Treinamento Técnico, Dimensão Ambiental”, PEA - USP, São Paulo, 2006.

[47]UDAETA, M.E.M., et alii; "Relatório Técnico Científico Parcial 1- Oficina de PIR - Treinamento Técnico, Dimensão Social”, PEA - USP, São Paulo, 2006.

[48]UDAETA, M.E.M., et alii; "Relatório Técnico Científico Parcial 1- Guia de Dados”, PEA - USP, São Paulo, 2006.

[49]UDAETA, M.E.M., et alii; "Relatório Técnico Científico Parcial 1- Mina de Dados", PEA - USP, São Paulo, 2006.

[50]UDAETA, M.E.M., et alii; "Relatório Técnico Científico Parcial 1Georreferenciamento”, PEA - USP, São Paulo, 2006.

[51]UDAETA, M.E.M., et alii; "Relatório Técnico Científico Parcial 1- Guia de Dados”, PEA - USP, São Paulo, 2006.

[52]UDAETA, M.E.M., et alii; "Relatório Técnico Científico Parcial 1 Inventário Ambiental”, PEA - USP, São Paulo, 2006.

[53]UDAETA, M.E.M., et alii; "Relatório Técnico Científico Parcial 1- AHP e Decision Lens", PEA - USP, São Paulo, 2006. 
[54]UDAETA, M.E.M., et alii; "Relatório Técnico Científico Parcial 1- Cálculo de Potenciais Energéticos”, PEA - USP, São Paulo, 2006.

[55]UDAETA, M.E.M., et alii,

[56]UNDP. "World Energy Assessment: Energy and the challenge of sustainability". United Nations Development Programme. Nova Iorque. 2000.

[57]PROCEL - Programa Nacional de Conservação de Energia Elétrica - Eletrobrás Ministério de Minas e Energia. http://www.eletrobras.gov.br/procel/

[58] UDAETA, M.E.M., BAITELO, R.L. “Aspectos Políticos do Gerenciamento do Lado da Demanda”. CBR - Congresso Brasileiro de Regulação, Manaus, 2005.

[59]KANAYAMA, P.H., "Modelamento da Integração de Recursos Energéticos Dentro do Pir"

[60]UDAETA, M.E.M., et alii; "Relatório Técnico Científico Parcial 2 (na versão completa)”, PEA - USP, São Paulo, 2008.

[61]CICONE, D.J., "Modelagem e Aplicação da Avaliação de Custos Completos Através do Método de Análise Hierárquica Dentro do Planejamento Integrado de Recursos" Tese de doutorado apresentada à Escola Politécnica da Universidade de São Paulo, São Paulo, (2007) 